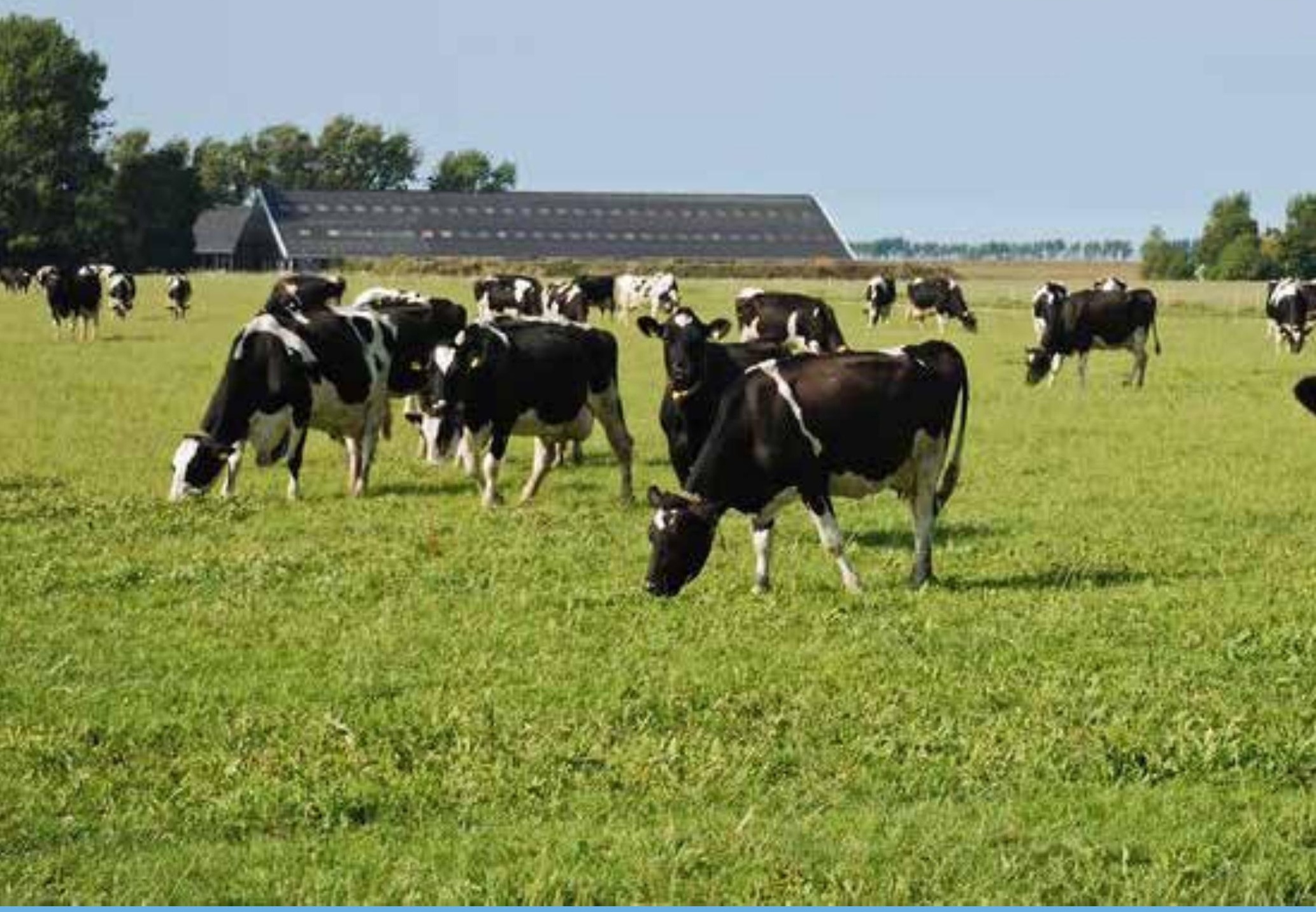

\title{
Toetsing van Kritische Prestatie Indicatoren voor biodiversiteit op melkveebedrijven
}

Nick van Eekeren, Nyncke Hoekstra, Monique Bestman, Pieter Willem Blokland, Nico Polman en Jelle Zijlstra 



\title{
Toetsing van Kritische Prestatie Indicatoren voor biodiversiteit op melkveebedrijven
}

Nick van Eekeren, ${ }^{2}$ Nyncke Hoekstra, ${ }^{2}$ Monique Bestman, ${ }^{2}$ Pieter Willem Blokland, ${ }^{1}$ Nico Polman ${ }^{1}$ en Jelle Zijlstra $^{3}$

\author{
1 Wageningen Economic Research \\ 2 Louis Bolk Instituut \\ 3 Wageningen Livestock Research
}

Dit onderzoek is uitgevoerd in opdracht van de Duurzame Zuivelketen en gefinancierd door ZuivelNL en het ministerie van Economische Zaken in het kader van de PPS Duurzame Zuivelketen, onderdeel van de topsector Agri\&Food

Wageningen Economic Research

Wageningen, oktober 2020

RAPPORT

2020-107

ISBN 978-94-6395-067-1 
Nick van Eekeren, Nyncke Hoekstra, Monique Bestman, Pieter Willem Blokland, Nico Polman en Jelle Zijlstra, 2020. Toetsing van Kritische Prestatie Indicatoren voor biodiversiteit op melkveebedrijven. Wageningen, Wageningen University \& Research, Rapport 2020-107. 64 blz.; 8 fig.; 21 tab.; 18 ref.

De Duurzame Zuivelketen (DZK) heeft als ambitie om de biodiversiteit op alle melkveebedrijven in Nederland in kaart te brengen en te bevorderen middels de 'Biodiversiteitsmonitor'. Dit rapport beschrijft de resultaten van een toetsing van de geselecteerde Kritieke Prestatie Indicatoren (KPI's) aan biodiversiteitsmetingen op melkveebedrijven. Het percentage grasland en het percentage blijvend grasland zijn bruikbaar als KPI voor biodiversiteit op bedrijfsniveau. De KPI's stikstofbodemoverschot per ha en percentage voereiwit van eigen bedrijf vertonen verbanden met enkele biodiversiteitsmetingen. Afhankelijk van de doelstelling rond biodiversiteit, zijn deze KPI's meer of minder bruikbaar als indicator voor biodiversiteit op een bedrijf.

The ambition of the Sustainable Dairy Chain (DZK) is to map out and promote biodiversity on all dairy farms in the Netherlands by means of the 'Biodiversity Monitor'. This report describes the results of an assessment of the selected Key Performance Indicators (KPIs) against biodiversity measurements on dairy farms. The percentage of grassland and the percentage of permanent grassland can be used as KPI for biodiversity at farm level. The KPI's nitrogen soil surplus per ha and percentage of feed protein from own farms are related to a number of biodiversity measurements. Depending on the biodiversity target, these KPIs can be used to a greater or lesser extent as an indicator of biodiversity on a farm.

Trefwoorden: Biodiversiteit, melkveehouderij, Kritieke Prestatie Indicatoren (KPI's)

Dit rapport is gratis te downloaden op https://doi.org/10.18174/497523 of op www.wur. nl/economicresearch (onder Wageningen Economic Research publicaties).

(C) 2020 Wageningen University \& Research

Postbus 29703, 2502 LS Den Haag, T 07033583 30, E communications.ssg@wur.nl, www.wur.nl/economic-research. Wageningen Economic Research is onderdeel van Wageningen University \& Research.

\section{(cc) BY-NC}

Dit werk valt onder een Creative Commons Naamsvermelding-Niet Commercieel 4.0 Internationaallicentie.

(c) Wageningen Economic Research, onderdeel van Stichting Wageningen Research, 2020 De gebruiker mag het werk kopiëren, verspreiden en doorgeven en afgeleide werken maken. Materiaal van derden waarvan in het werk gebruik is gemaakt en waarop intellectuele eigendomsrechten berusten, mogen niet zonder voorafgaande toestemming van derden gebruikt worden. De gebruiker dient bij het werk de door de maker of de licentiegever aangegeven naam te vermelden, maar niet zodanig dat de indruk gewekt wordt dat zij daarmee instemmen met het werk van de gebruiker of het gebruik van het werk. De gebruiker mag het werk niet voor commerciële doeleinden gebruiken.

Wageningen Economic Research aanvaardt geen aansprakelijkheid voor eventuele schade voortvloeiend uit het gebruik van de resultaten van dit onderzoek of de toepassing van de adviezen.

Wageningen Economic Research Rapport 2020-107 | Projectcode 2282700338

Foto omslag: Shutterstock 


\section{Inhoud}

$\begin{array}{ll}\text { Woord vooraf } & 5\end{array}$

$\begin{array}{ll}\text { Samenvatting } & 6\end{array}$

$\begin{array}{lr}\text { Begrippenlijst } & 10\end{array}$

1

Inleiding

11

1.1 Aanleiding 11

1.2 Doelstellingen $\quad 12$

$\begin{array}{ll}1.3 \text { Werkwijze in het kort } & 12\end{array}$

1.4 Verwachte relaties tussen KPI's en biodiversiteit $\quad 12$

2

Werkwijze

2.1 KPI's 14

2.2 Selectie onderzoeksbedrijven 14

$\begin{array}{lll}2.3 & \text { Indicatoren voor biodiversiteit } & 14\end{array}$

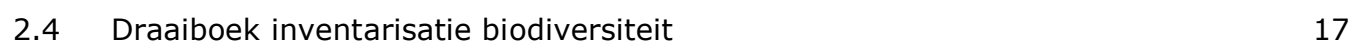

$\begin{array}{llr}2.5 & \text { Statistische analyse } & 18\end{array}$

3

$\begin{array}{lr}\text { Resultaten } & 19\end{array}$

$\begin{array}{lll}3.1 & \text { Verschillen tussen grondsoorten } & 19\end{array}$

3.2 Bodembiodiversiteit $\quad 20$

3.2.1 Effect van grondsoort en perceelstype $\quad 20$

$\begin{array}{ll}3.2 .2 \text { Verbanden met KPI's } & 22\end{array}$

$\begin{array}{lll}3.3 & \text { Regenwormen } & 23\end{array}$

3.3.1 Effect van grondsoort en perceelstype 23

$\begin{array}{ll}3.3 .2 \text { Verbanden met KPI's } & 24\end{array}$

$\begin{array}{lll}3.4 & \text { Graslandplanten } & 24\end{array}$

3.4.1 Effect van grondsoort en perceelstype $\quad 24$

$\begin{array}{ll}3.4 .2 \text { Verbanden met KPI's } & 25\end{array}$

$\begin{array}{lll}3.5 & \text { Insecten } & 26\end{array}$

3.5.1 Effect van grondsoort en perceelstype 26

3.5.2 Verbanden met KPI's $\quad 26$

$\begin{array}{lll}3.6 & \text { Vogels } & 27\end{array}$

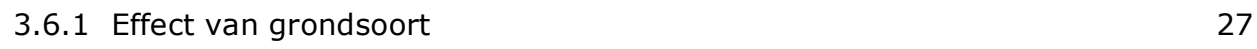

3.6.2 Verbanden met KPI's $\quad 28$

$\begin{array}{lll}3.7 & \text { Zoogdieren } & 29\end{array}$

3.7.1 Effect van grondsoort $\quad 29$

$\begin{array}{ll}3.7 .2 \text { Verbanden met KPI's } & 29\end{array}$

$\begin{array}{lll}3.8 & \text { Synthese } & 30\end{array}$

4

$\begin{array}{ll}\text { Discussie } & 31\end{array}$

$\begin{array}{lll}4.1 & \text { Steekproefgrootte } & 31\end{array}$

$\begin{array}{lll}4.2 & \text { Evaluatie biodiversiteitsindicatoren } & 31\end{array}$

4.2.1 Bodemindicatoren 31

4.2.2 Wormen 31

4.2.3 Planten 32

4.2.4 Insecten $\quad 32$

4.2.5 Vogels 33

4.2.6 Zoogdieren 33 
4.3 Relatie tussen KPI's en biodiversiteit 33

4.3.1 Percentage grasland en perceelstype 33

4.3.2 Percentage blijvend grasland en leeftijd van grasland $\quad 34$

4.3.3 Percentage toepassing groenbemester $\quad 34$

4.3.4 Stikstofbodemoverschot per ha $\quad 35$

4.3.5 Ammoniakemissie per hectare $\quad 35$

4.3.6 Percentage voereiwit eigen bedrijf $\quad 35$

4.3.7 Grasopbrengst per ha $\quad 35$

4.3.8 Bruikbaarheid van de KPI's als indicator voor biodiversiteit 36

5.1 Bruikbaarheid van KPI's als indicator voor biodiversiteit 38

$\begin{array}{lll}5.2 & \text { Grondsoort en biodiversiteit } & 39\end{array}$

5.3 Aanbevelingen voor communicatie en vervolgactiviteiten 39

Literatuur en websites

Bijlage 1 Steekproef Bedrijveninformatienet van Wageningen Economic Research

Bijlage 2 Resultaten ANOVA's in tabelvorm $\quad 44$

Bijlage 3 Resultaten correlaties in tabelvorm $\quad 46$

Bijlage 4 Resultaten regressieanalyses in tabelvorm $\quad 53$

Bijlage 5 Beschrijving resultaten op basis van correlaties en regressieanalyses 


\section{Woord vooraf}

De Duurzame Zuivelketen is een uniek initiatief van de Nederlandse Zuivel Organisatie (NZO) en LTO Nederland waarin de zuivelindustrie en melkveehouders gezamenlijk streven naar verduurzaming van de Nederlandse zuivelsector. De Duurzame Zuivelketen (DZK) ziet het belang van behoud van biodiversiteit voor de melkveehouderij. Melkveebedrijven zijn afhankelijk van natuurlijke processen en zijn daardoor gebaat bij een rijke biodiversiteit. Wageningen Research en het Louis Bolk Instituut willen graag bijdragen aan het realiseren van deze verduurzaming door een bijdrage te leveren aan de onderbouwing van de biodiversiteitsmonitor melkveehouderij.

Naast het daadwerkelijk behoud en waar mogelijk herstel van de biodiversiteit is het van belang ook daadwerkelijk aan te tonen wat melkveehouders doen om dit te realiseren. Daarom is de ontwikkeling van een onderbouwde monitoringsystematiek voor biodiversiteit een belangrijk onderdeel van het Programma Biodiversiteit en Milieu binnen de Duurzame Zuivelketen. De resultaten uit het onderzoek zijn input voor deze verdere ontwikkeling van de monitoringsystematiek voor biodiversiteit. Deze monitoringssystematiek is nog in ontwikkeling. De resultaten kunnen daarom niet op zichzelf staand gezien worden. Ze zijn een stap geweest in een uitgebreid proces om uiteindelijk tot een monitoringsystematiek voor biodiversiteit in de melkveehouderij te komen.

Dit onderzoek is uitgevoerd onder verantwoordelijkheid van Wageningen Research in samenwerking met het Louis Bolk Instituut en in opdracht van en gefinancierd door het Duurzame Zuivelketen/Zuivel NL en het ministerie van Landbouw, Natuur en Voedselkwaliteit (LNV), binnen de Topsector Agri \& Food, roadmap Duurzame Veehouderij, Duurzame Zuivelketen, TKI-AF-15221 - Thema Biodiversiteit.

Ik wil bij dezen ook graag het programmateam vanuit DZK danken voor hun begeleiding van het project en de waardevolle feedback op de verschillende stappen in het project.

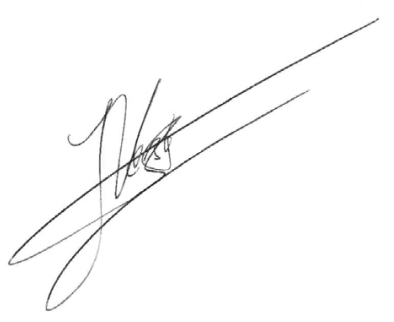

Prof.dr.ir. J.G.A.J. (Jack) van der Vorst Algemeen Directeur Social Sciences Group (SSG) Wageningen University \& Research 


\section{Samenvatting}

\section{Inleiding}

De Duurzame Zuivelketen (DZK) heeft als ambitie om de biodiversiteit op alle melkveebedrijven in Nederland in kaart te brengen en te bevorderen middels de 'Biodiversiteitsmonitor' (Van Laarhoven et al., 2018). Via verschillende onderzoeken wordt gezocht naar de beste indicatoren. In opdracht van DZK en van het consortium Rabobank, Wereld Natuur Fonds en FrieslandCampina hebben respectievelijk Van Eekeren et al. (2015), Zijlstra et al. (2017) en Zanen (2017) een aantal Kritieke Prestatie Indicatoren (KPI's) geselecteerd voor opname in de biodiversiteitsmonitor. Zijlstra et al. (2017) hebben zes KPI's geselecteerd voor opname in de biodiversiteitsmonitor onder de pijler functionele agrobiodiversiteit. Deze KPI's zouden een indruk moeten geven van de functionele agrobiodiversiteit op een melkveebedrijf en van de impact van een melkveehouderijbedrijf op de biodiversiteit op het bedrijf, in de nabije omgeving en op afstand. Dit rapport beschrijft de resultaten van een toetsing van de geselecteerde KPI's aan biodiversiteitsmetingen op melkveebedrijven.

\section{KPI's en onderzoeksmethode}

De onderzochte KPI's zijn:

1. Grasland in \% van de totale bedrijfsoppervlakte

2. Blijvend grasland in \% van de totale bedrijfsoppervlakte IDEM

3. Groenbemester als nateelt in \% van oppervlakte voedergewas

4. Stikstofbodemoverschot per ha zoals berekend in de KringloopWijzer

5. $\mathrm{NH}_{3}$-emissie per ha, zoals berekend in de KringloopWijzer

6. Voereiwit geproduceerd op het eigen bedrijf als \% totaal voer

Hieronder staan de hypotheses met betrekking tot de relaties tussen de afzonderlijke KPI's en biodiversiteit en het niveau waarop effecten verwacht worden: perceel, individueel melkveebedrijf, nationaal, regionaal en internationaal:

- Grasland in \% van totale bedrijfsoppervlakte van een melkveebedrijf wordt geacht een positieve invloed te hebben op de biodiversiteit op het bedrijf zelf en regionaal.

- Blijvend grasland in \% van totale bedrijfsoppervlakte wordt geacht een positief effect te hebben op biodiversiteit, omdat de verwachting is dat de biodiversiteit toeneemt naarmate grasland ouder is.

- Groenbemester als nateelt in \% van oppervlakte voedergewas wordt geacht een positieve invloed te hebben op de biodiversiteit op de betreffende bouwlandpercelen.

- Het stikstofbodemoverschot wordt geacht een negatieve invloed te hebben op de biodiversiteit in de regio als gevolg van eutrofiëring van het oppervlaktewater. Daarnaast zou het een positief effect op biodiversiteit op perceels- en bedrijfsniveau kunnen hebben doordat regenwormen profiteren van de beschikbare stikstof en de daaraan gebonden koolstof. Daarnaast zou op perceels- en bedrijfsniveau ook een negatief effect kunnen optreden, omdat overbemesting leidt tot dominantie door stikstofminnende plantensoorten.

- Van de $\mathrm{NH}_{3}$-emissie is bekend dat het via verzuring invloed heeft op natuurgebieden in de omgeving; er wordt echter geacht geen (of een heel beperkt) direct effect te zijn op perceels- en bedrijfsniveau.

- Voereiwit geproduceerd op het eigen bedrijf als \% totaal voer wordt geacht een positief effect te hebben op de biodiversiteit in de gebieden waar de geïmporteerde soja wordt verbouwd. Op perceels- en bedrijfsniveau kan een hoger percentage voereiwit geproduceerd op het eigen bedrijf als \% totaal voer worden bereikt door de combinatie van een lagere meetmelkproductie per ha en hogere $\mathrm{N}$-productie uit gras per ha. Deze beide indicatoren zijn daarom ook meegenomen in het onderzoek.

Voor dit onderzoek zijn in het voorjaar van 2017 op 36 melkveebedrijven in het Bedrijveninformatienet biodiversiteitsmetingen uitgevoerd. Deze bedrijven waren geselecteerd op basis van grondsoort (zand, klei, veen), intensiteit (melkproductie per hectare) en vier 'biodiversiteitsklassen' op basis van de score op de bovengenoemde KPI's. Op perceelsniveau zijn 
metingen gedaan aan bodemgezondheid, regenwormen, graslandplanten en insecten. Daarnaast is op bedrijfsniveau informatie verzameld over het voorkomen van vogels en zoogdieren. De op deze manier verzamelde biodiversiteitsgegevens zijn samen met de KPI's in een database opgenomen. Met behulp van verschillende statistische methoden (ANOVA en regressieanalyses) zijn relaties tussen KPI's en indicatoren voor biodiversiteit onderzocht, evenals de invloed van grondsoorten en drie perceeltypen (gras gemiddeld, gras divers en bouwland) op deze indicatoren.

\section{Resultaten en conclusies}

We vonden relaties tussen KPI's en verschillende vormen van biodiversiteit. Deze relaties verschillen tussen grondsoorten en perceelstypen. In onderstaande Tabel S.1 staat op welk schaalniveau verbanden zijn gevonden tussen KPI's en biodiversiteitsmetingen. Op basis hiervan trekken we een conclusie over de bruikbaarheid van de KPI's als indicator voor biodiversiteit op melkveebedrijven. Deze beoordeling heeft plaatsgevonden op basis van de significantie en de eenduidigheid van de gevonden relaties.

Tabel S.1 Het verband tussen KPI's en biodiversiteit op perceels- en bedrijfsniveau (+ is een significant positief correlatie, - is een significant negatief correlatie, - / + is een niet eenduidig verband, 0 is geen significant verband en een leeg vakje betekent niet onderzocht)

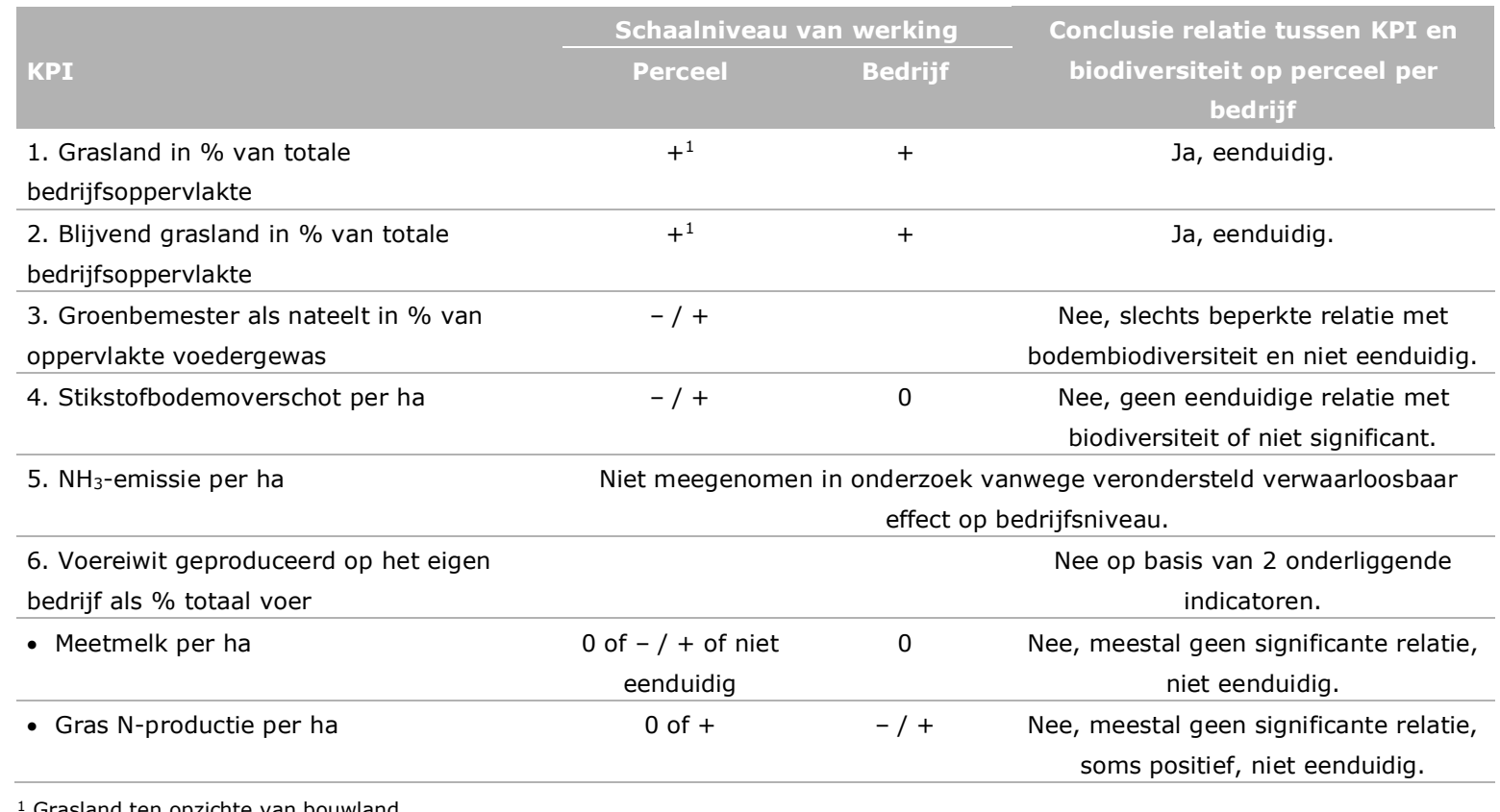

1 Grasland ten opzichte van bouwland

Grasland in \% van totale bedrijfsoppervlakte

Het effect van grasland in \% van totale bedrijfsoppervlakte op biodiversiteit op perceelsniveau wordt in dit onderzoek allereerst weergegeven op basis van het verschil tussen biodiversiteitsmetingen voor gras- en maïsland. De bodembiodiversiteit (op basis van Soil Health Index en bodemleven) was hoger onder grasland dan onder bouwland. Op bedrijfsniveau vonden we op veengrond een positief verband tussen het grasland in \% van totale bedrijfsoppervlakte en het aantal soorten wormeneters (weidevogels) en roofvogels, maar in het algemeen een negatief verband met het aantal soorten insectenetende vogels. Het grasland in \% van totale bedrijfsoppervlakte is dus zowel op perceelsniveau als op bedrijfsniveau positief gerelateerd aan meerdere (maar niet alle) biodiversiteitsmetingen. Deze KPI is daarmee bruikbaar als indicator voor biodiversiteit op het bedrijf.

Blijvend grasland in \% van totale bedrijfsoppervlakte

Op perceelsniveau was er over het algemeen een positief verband tussen de graslandleeftijd en bodembiodiversiteit; afhankelijk van de grondsoort waren er daarnaast ook positieve verbanden met wormenindicatoren, het totaal aantal plantensoorten en het aantal kruidensoorten. Op bedrijfsniveau waren er met name op zand meer wormeneters (weidevogels) bij een hoger aandeel blijvend grasland. Deze KPI is daarmee bruikbaar als indicator voor biodiversiteit op het bedrijf. 
Groenbemester als nateelt in \% van oppervlakte voedergewas

Op zandgrond vindt groenbemester algemeen toepassing - vanwege de wettelijke verplichting daartoe - terwijl dat op kleigrond niet het geval is. Deze situatie maakte het moeilijk om relaties tussen groenbemester als nateelt in \% van oppervlakte voedergewas en biodiversiteitsmetingen vast te stellen. In het algemeen geldt dat groenbemester wel het organischestofgehalte kan verhogen (goed voor biodiversiteit), maar geen extra voedsel voor bijvoorbeeld vogels oplevert. In dit onderzoek hebben we niet kunnen aantonen dat deze KPI bruikbaar is als indicator voor biodiversiteit op het bedrijf.

\section{Stikstofbodemoverschot}

Het stikstofbodemoverschot was over het algemeen positief gerelateerd aan bodembiodiversiteit (op basis van Soil Health Index en Eurofins bodemleven-metingen). Echter, dit effect werd sterk beïnvloed door grondsoort. Bijvoorbeeld op zandgrond was het gewicht per worm hoger bij een hoger stikstofbodemoverschot. Op basis van deze resultaten is de conclusie dat deze KPI niet bruikbaar is als indicator voor biodiversiteit op het bedrijf.

Voereiwit geproduceerd op het eigen bedrijf als \% totaal voer

De relatie tussen deze KPI en biodiversiteitsmetingen is beoordeeld op basis van twee onderliggende indicatoren: meetmelkproductie per ha en $\mathrm{N}$-productie uit gras per ha.

\section{Meetmelk per ha}

Er was geen verband tussen meetmelk per ha en biodiversiteit op perceelsniveau. Er waren geen significante correlaties met bodemindicatoren. Het effect op de wormenindicatoren was zeer wisselend en sterk afhankelijk van grondsoort. Er was geen consistent verband met het aantal kruidensoorten, ook niet met de insectenindicatoren. Er was evenmin een verband tussen meetmelk per ha en biodiversiteit op bedrijfsniveau (vogelsoorten en zoogdieren). De conclusie is dat deze indicator niet bruikbaar is om biodiversiteit te meten op een bedrijf.

\section{Gras N-productie per ha}

Grasproductie uitgedrukt in $\mathrm{kg}$ stikstof per ha was over het algemeen positief gerelateerd aan de bodembiodiversiteit en wormenindicatoren. Op veengrond is het verband met kruidensoorten negatief. De causaliteit in deze relatie is naar verwachting dat een betere bodembiodiversiteit resulteert in een hogere grasproductie. Op bedrijfsniveau maten we zowel positieve als negatieve verbanden tussen grasproductie en aantallen vogelsoorten, hazen en reeën. Alles overziend is de conclusie dat deze indicator niet bruikbaar is om biodiversiteit te meten op het bedrijf.

\section{Discussie}

Grasland in \% van totale bedrijfsoppervlakte en blijvend grasland in \% van totale bedrijfsoppervlakte zijn bruikbaar als KPI voor biodiversiteit op bedrijfsniveau. De KPI's stikstofbodemoverschot per ha en voereiwit geproduceerd op het eigen bedrijf als \% totaal voer vertonen wel verbanden met enkele biodiversiteitsmetingen: soms met bodemvruchtbaarheid en soms met wormen. Afhankelijk van de doelstelling rond biodiversiteit, zijn deze KPI's meer of minder bruikbaar als indicator voor biodiversiteit op een bedrijf. Biodiversiteitsmetingen vertonen soms negatieve onderlinge verbanden. Dan wordt de ene biodiversiteitsindicator positief beïnvloed, maar tegelijkertijd wordt een andere biodiversiteitsindicator negatief beïnvloed. Verbeteren van biodiversiteit op melkveebedrijven vergt dus maatwerk en keuzes ten aanzien van biodiversiteitsdoelen. De te treffen maatregelen zijn ook afhankelijk van grondsoort en gewas.

Relaties met biodiversiteit buiten het bedrijf vallen buiten de scope van dit onderzoek. Zijlstra et al. (2017) stellen op basis van literatuurstudie dat de KPI's stikstofbodemoverschot en voereiwit geproduceerd op het eigen bedrijf als \% totaal voer bruikbaar zijn voor het bevorderen van biodiversiteit vanwege de veronderstelde impact op biodiversiteit buiten het bedrijf. Het feit dat dit onderzoek voor een aantal KPI's aantoont dat ze niet bruikbaar zijn als indicator voor biodiversiteit op een melkveebedrijf, wil dus niet zeggen dat ze niet bruikbaar zijn als indicator voor de impact op biodiversiteit buiten het bedrijf. 
Van de 36 onderzochte bedrijven lagen er 12 op klei, 13 op veen en 11 op zand. Er bleken grote verschillen tussen grondsoorten voor wat betreft het aandeel blijvend grasland, graslandleeftijd, groenbemester als nateelt in \% van oppervlakte voedergewas en stikstofbodemoverschot. Ook waren de verbanden die we vonden op de ene grondsoort niet altijd gelijk aan die op de andere grondsoorten. Werkingsmechanismen tussen bedrijfsvoering en biodiversiteit kunnen dus verschillen per grondsoort. Verder is er ook nog interactie tussen grondsoorten en landschapstypen. Zandgrond heeft bijvoorbeeld meer gesloten landschapstypen met een andere biodiversiteit dan veengrond met juist een meer open landschapstype. Inzetten van KPI's vereist dus maatwerk per regio, waarbij zowel grondsoort als landschapstype bepalend zijn om regionale biodiversiteitsdoelen te stellen.

Dit onderzoek toont aan dat zowel extensieve als intensieve bedrijven binnen de intensiteitsklasse van het Bedrijveninformatienet potentie hebben voor de ontwikkeling van biodiversiteit. Verder heeft leeftijd van grasland veel invloed op biodiversiteit en zijn enkele positieve verbanden gevonden tussen biodiversiteitsmetingen en grasopbrengst per ha. Dit zijn belangrijke resultaten voor de communicatie over biodiversiteit met melkveehouders.

Het verzamelde onderzoekmateriaal leent zich voor nadere analyses met betrekking tot biodiversiteit op melkveebedrijven. Bij een grotere steekproef voor meerdere jaren zouden we meer, sterker significante en wellicht ook eenduidiger verbanden tussen KPI's en gemeten biodiversiteit kunnen verwachten. Een grotere steekproef voor meerdere jaren was echter binnen de kaders van deze studie niet mogelijk, maar dit heeft dus mogelijk wel consequenties gehad voor de resultaten. De resultaten zijn geïnterpreteerd in samenhang met de correlaties over alle bedrijven en binnen de grondsoorten. De tijdens de bedrijfsbezoeken verzamelde informatie (onder andere foto's) en ervaringen kunnen worden gebruikt om maatregelen te omschrijven en te illustreren in documentatie over biodiversiteit voor melkveehouders. 


\section{Begrippenlijst}

\begin{tabular}{|c|c|}
\hline Begrip & Uitleg \\
\hline ANOVA & $\begin{array}{l}\text { ANalysis Of VAriance. Een ANOVA-test is een toets die aan de hand van de variantie } \\
\text { aantoont of gemiddelden van meer dan twee groepen significant van elkaar } \\
\text { verschillen. }\end{array}$ \\
\hline Bedrijveninformatienetwerk & $\begin{array}{l}\text { Het Bedrijveninformatienet is een panel van } 1.500 \text { land- en tuinbouwbedrijven, } \\
\text { visserij- en particuliere bosbouwbedrijven, waaronder circa } 250 \text { gespecialiseerde } \\
\text { melkveebedrijven. Door de opzet en de keuze van bedrijven representeert dit panel } \\
\text { (bijna) de hele Nederlandse land- en tuinbouw. }\end{array}$ \\
\hline Biodiversiteit & De diversiteit van planten en dieren in samenhang. \\
\hline Biodiversiteitsmonitor & $\begin{array}{l}\text { Een gezamenlijk initiatief van FrieslandCampina, Rabobank en het Wereld Natuur } \\
\text { Fonds (Van Laarhoven et al., 2017). Hulpmiddel bij het sturen en meten door middel } \\
\text { van Kritieke Prestatie Indicatoren (KPI's) van de invloed die een individueel } \\
\text { melkveebedrijf heeft op biodiversiteit en andere ecosysteemdiensten op het } \\
\text { boerenbedrijf en daarbuiten. }\end{array}$ \\
\hline Drukfactor & $\begin{array}{l}\text { De Bie (2013) onderscheidde } 9 \text { drukfactoren die biodiversitiet kunnen beïnvloeden: } \\
\text { energie (incl. } \mathrm{CO}_{2} \text {-emissie), landgebruik, emissies naar lucht en water, landschap, } \\
\text { bodemgebruik, watergebruik, middelengebruik en licht \& geluid. }\end{array}$ \\
\hline Functionele agrobiodiversiteit & $\begin{array}{l}\text { De kringloop op het bedrijf (bestaande uit de onderdelen bodem, gewas, koe en } \\
\text { bedrijfssysteem) als basis voor onder- en bovengrondse biodiversiteit, } \\
\text { watermanagement, koolstofvastlegging, nutriëntengebruik, enzovoort (Erisman et al., } \\
\text { 2014). }\end{array}$ \\
\hline Indicator & $\begin{array}{l}\text { Een meetbaar fenomeen dat een signalerende functie heeft en een aanwijzing is voor } \\
\text { de kwantiteit of de kwaliteit van een bedrijfsproces. }\end{array}$ \\
\hline Indirecte indicator & $\begin{array}{l}\text { Alternatief voor een indicator die niet eenvoudig waarneembaar is of slechts tegen } \\
\text { hoge kosten meetbaar. }\end{array}$ \\
\hline Kritieke Prestatie Indicator (KPI) & $\begin{array}{l}\text { Een indicator voor het monitoren en analyseren van prestaties van ondernemingen } \\
\text { als onderdeel van de biodiversiteitsmonitor. In dit rapport wordt met 'KPI's' } \\
\text { gerefereerd aan de indicatoren die in twee eerdere onderzoeken (Zijlstra et al., 2017; } \\
\text { Zanen, 2017) zijn geselecteerd als zijnde de beste indicatoren voor biodiversiteit op } \\
\text { Nederlandse melkveebedrijven. }\end{array}$ \\
\hline Regressieanalyse & $\begin{array}{l}\text { Eén van de meest gebruikte technieken in kwantitatief onderzoek. Met } \\
\text { regressieanalyse probeert men de waargenomen spreiding in een (meetbare) } \\
\text { afhankelijke variabele te verklaren met behulp van onafhankelijke verklarende } \\
\text { variabelen. }\end{array}$ \\
\hline Variabele & Een meetbaar kenmerk van een bedrijf. \\
\hline
\end{tabular}




\section{$1 \quad$ Inleiding}

\section{$1.1 \quad$ Aanleiding}

De Duurzame Zuivelketen (DZK) heeft als ambitie om de biodiversiteit op alle melkveebedrijven in Nederland in kaart te brengen en te bevorderen middels de 'Biodiversiteitsmonitor' (Van Laarhoven et.al., 2018). Deze biodiversiteitsmonitor 'meet door middel van Kritieke Prestatie Indicatoren (KPI's) de invloed die een individueel melkveebedrijf heeft op biodiversiteit op het boerenbedrijf en daarbuiten. Zo kan de inzet van melkveehouders voor behoud van natuur en landschap op een uniforme manier gemonitord worden.' De basis voor de biodiversiteitsmonitor is het conceptueel kader dat Erisman et al. (2014) beschreven voor de inpassing van vier samenhangende pijlers van biodiversiteit op melkveebedrijven. Via verschillende onderzoeken wordt gezocht naar de beste indicatoren die kunnen dienen als Kritische Prestatie Indicatoren (KPI). Deze set van KPI's vormen de basis voor de integrale aansturing en meting van de duurzaamheid van een melkveebedrijf via de monitor. In opdracht van het consortium Rabobank/WNF/FrieslandCampina en DZK hebben Zijlstra et al. (2017) en Zanen (2017) in navolging van een studie van Van Eekeren et al., (2015) een aantal KPI's geselecteerd voor opname in de biodiversiteitsmonitor. De KPI's in Zijlstra et al. (2017) zouden een indruk moeten geven van de functionele agrobiodiversiteit ${ }^{1}$ op een melkveebedrijf, van de landschappelijke diversiteit en van specifieke soorten. ${ }^{2}$ Onder functionele agrobiodiversiteit verstaan we de kringloop op het bedrijf met als onderdelen bodem, gewassen, vee en bedrijfssysteem.

Zijlstra et al. (2017) adviseren met betrekking tot de functionele agrobiodiversiteit de onderstaande KPI's op te nemen in de biodiversiteitsmonitor. Deze zijn beschikbaar via de KringloopWijzer:

1. Grasland in \% van totale bedrijfsoppervlakte van de totale bedrijfsoppervlakte

2. Blijvend grasland in \% van totale bedrijfsoppervlakte van de totale bedrijfsoppervlakte

3. Groenbemester als nateelt in \% van oppervlakte voedergewas Groenbemester als nateelt in \% van oppervlakte voedergewas

4. Stikstofbodemoverschot per ha zoals berekend in de KringloopWijzer

5. $\mathrm{NH}_{3}$-emissie per ha, zoals berekend in de KringloopWijzer

6. \% voereiwit geproduceerd op het eigen bedrijf

Daarnaast heeft Zanen (2017) een aantal KPI's voorgesteld voor landschappelijke diversiteit op het bedrijf en specifieke soorten, welke nog niet beschikbaar zijn via databases en nog verder uitgewerkt moeten worden:

1. $\%$ beheerde lijnelementen van het totaal aantal meters lijnelementen op het bedrijf

2. \% niet-productief land van de totale bedrijfsoppervlakte

3. \% extensief beheerd land van de totale bedrijfsoppervlakte

4. \% kruidenrijk grasland van de totale graslandoppervlakte

5. \% onverhard erf van de totale erfoppervlakte

DZK heeft via het Programmateam Biodiversiteit \& Milieu opdracht gegeven om de KPI's uit Zijlstra et al. (2017) te toetsen aan de daadwerkelijke biodiversiteit (dus de soortenrijkdom) op melkveebedrijven.

\footnotetext{
1 De 1 e pijler van de 4 pijlers voor biodiversiteit in de indeling van Erisman et al. (2014) en Van Eekeren et al. (2015).

2 De 2 e en 3 e pijler van de 4 pijlers voor biodiversiteit in de indeling van Erisman et al. (2014) en Van Eekeren et al. (2015).
} 


\subsection{Doelstellingen}

Het project heeft 3 doelstellingen:

- Toetsen of de geselecteerde KPI's voor functionele agrobiodiversiteit (Zijlstra et al., 2017) gerelateerd zijn aan de werkelijke biodiversiteit op melkveebedrijven uit het Bedrijveninformatienet van Wageningen Economic Research. ${ }^{3}$ Dit leidt tot een aanvullende wetenschappelijke validatie van de KPI's en ondersteunt het gebruik van de KPI's in de biodiversiteitsmonitor.

- Als de uitkomsten van de toets daartoe aanleiding geven, aanbevelingen doen voor aanpassing van de KPI's. KOMT in samenvatting niet terug

- Als de uitkomsten van de toets daar aanleiding toe geven, aanbevelingen doen voor maatregelen voor uiteenlopende typen melkveebedrijven. KOMT in samenvatting niet terug.

\subsection{Werkwijze in het kort}

In het voorjaar van 2017 is op 36 melkveebedrijven van het Bedrijveninformatienet de biodiversiteit bepaald: de functionele agrobiodiversiteit, de soortenrijkdom van planten en dieren en landschappelijke diversiteit. Voor de keuze van bedrijven en de metingen is gebruikgemaakt van literatuur en expertkennis. Van deze 36 bedrijven worden in het kader van het Bedrijveninformatienet al allerlei (economische en technische) kengetallen verzameld, waaronder de KPI's uit Zijlstra et al. (2017). De scores van deze 36 bedrijven op de KPI's uit Zijlstra et al. (2017) en de scores met betrekking tot de biodiversiteit zijn in één database opgenomen. Er zijn correlaties berekend tussen KPI's en biodiversiteitsscores, er zijn ANOVA's en regressieanalyses uitgevoerd. Zie hoofdstuk 2 voor de uitgebreide beschrijving van de werkwijze. De conceptresultaten zijn besproken binnen het projectteam, met het Programmateam Biodiversiteit \& Milieu en met vertegenwoordigers van Rabobank en Wereldnatuurfonds.

\subsection{Verwachte relaties tussen KPI's en biodiversiteit}

Op basis van de stand van kennis voor de start van het onderzoek waren er al verwachtingen met betrekking tot de relaties tussen KPI's en biodiversiteit (zie Tabel 1). In deze tabel staan de 6 KPI's uit Zijlstra et al. (2017) met het schaalniveau waarop ze verwacht worden effect te hebben. Aanvullend zijn voor enkele KPI's op bedrijfsniveau een 'afgeleide KPI' gekozen om een relatie te kunnen leggen op perceelsniveau (de KPI's zonder nummer).

Grasland in \% van totale bedrijfsoppervlakte van een melkveebedrijf wordt geacht positieve invloed te hebben op de biodiversiteit op het bedrijf zelf, maar ook regionaal. Indien er bijvoorbeeld voedsel voor weidevogels beschikbaar is in het grasland, kunnen weidevogels uit de directe omgeving van het bedrijf daarvan gebruikmaken. Op perceelsniveau kan deze KPI het best worden gekarakteriseerd als het effect van grasland in vergelijking met bouwland, dus het perceelstype.

De KPI blijvend grasland in \% van totale bedrijfsoppervlakte heeft een positief effect op biodiversiteit, omdat deze KPI gebaseerd is op de verwachting dat de biodiversiteit toeneemt naarmate grasland ouder is. Dit vanwege het oplopende organischestofgehalte, dat naar verwachting leidt tot een meer divers bodemleven. Op perceelsniveau kan deze KPI worden weergegeven als de graslandleeftijd.

Van groenbemester als nateelt in \% van oppervlakte voedergewas wordt verwacht dat het een positieve invloed heeft op de biodiversiteit op de betreffende bouwlandpercelen. In het onderzoek is groenbemester als nateelt in \% van oppervlakte voedergewas meegenomen, maar omdat groenbemesters op zand verplicht zijn en dus alle veehouders een groenbemester hebben en op klei niet, is het niet mogelijk om hier zuivere conclusies over te trekken.

\footnotetext{
3 Het Bedrijveninformatienet van Wageningen Economic Research is een panel van 1.500 land- en tuinbouwbedrijven, visserij- en particuliere bosbouwbedrijven.
} 
Voor het stikstofbodemoverschot is de verwachting dat het via eutrofiëring als gevolg van een hoog stikstofbodemoverschot van het oppervlaktewater een negatieve invloed heeft op de biodiversiteit in de regio. Tegelijk zou het op perceels- en bedrijfsniveau een positief effect kunnen hebben, doordat regenwormen profiteren van een hoger stikstofgehalte in combinatie met extra aanvoer van aan de stikstof gebonden koolstof. Echter, daarnaast zal het op perceels- en bedrijfsniveau ook een negatief effect hebben, omdat overbemesting leidt tot dominantie door stikstof minnende plantensoorten en een negatief effect heeft op de kwaliteit van het oppervlaktewater. In het onderzoek worden beide

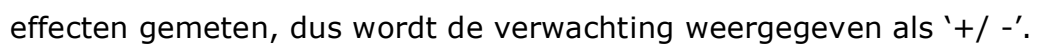

Van de $\mathrm{NH}_{3}$-emissie is bekend dat het via bijdrage aan eutrofiering en verzuring invloed heeft op natuurgebieden in de omgeving, echter er wordt geen direct of een beperkt effect (bijvoorbeeld landschapselementen op het bedrijf) verwacht op perceels- en bedrijfsniveau. Om deze reden wordt deze KPI niet betrokken in het verdere onderzoek.

Van voereiwit geproduceerd op het eigen bedrijf als \% totaal voer wordt verwacht dat het een positief effect heeft op de biodiversiteit in de gebieden waar de geïmporteerde soja wordt verbouwd. Op perceels- en bedrijfsniveau kan een hoger percentage voereiwit geproduceerd op het eigen bedrijf als $\%$ totaal voer worden bereikt door de combinatie van een lagere meetmelkproductie per ha en hogere $\mathrm{N}$-productie uit gras per ha. Daarom zijn de verwachtingen voor deze beide indicatoren apart weergegeven. Een hogere meetmelkproductie per ha gaat over het algemeen gepaard met een groter aandeel maïs in het bouwplan en met het streven naar hogere $\mathrm{N}$-opbrengsten uit gras per ha. Daarom wordt voor deze indicator een negatief effect op biodiversiteit verwacht. Voor een hogere $\mathrm{N}$-opbrengst uit gras per ha wordt hetzelfde verwacht. Wanneer deze beide indicatoren worden gecombineerd in het percentage voereiwit geproduceerd op het eigen bedrijf als \% totaal voer, blijkt dat bedrijven met een laag percentage voereiwit geproduceerd op het eigen bedrijf als $\%$ totaal voer over het algemeen intensieve bedrijven zijn met maïs in het bouwplan. Bedrijven die hoog scoren op dit kengetal zijn over het algemeen bedrijven met een lagere intensiteit en een groot aandeel gras in het bouwplan. De inschatting is dat deze laatste groep over het algemeen een hoger biodiversiteit toont op perceels- en bedrijfsniveau.

Het in dit rapport beschreven onderzoek beperkt zich tot de schaalniveaus perceel en bedrijf.

Tabel 1 Verwacht effect van KPI's op biodiversiteit op de verschillende schaalniveaus van werking

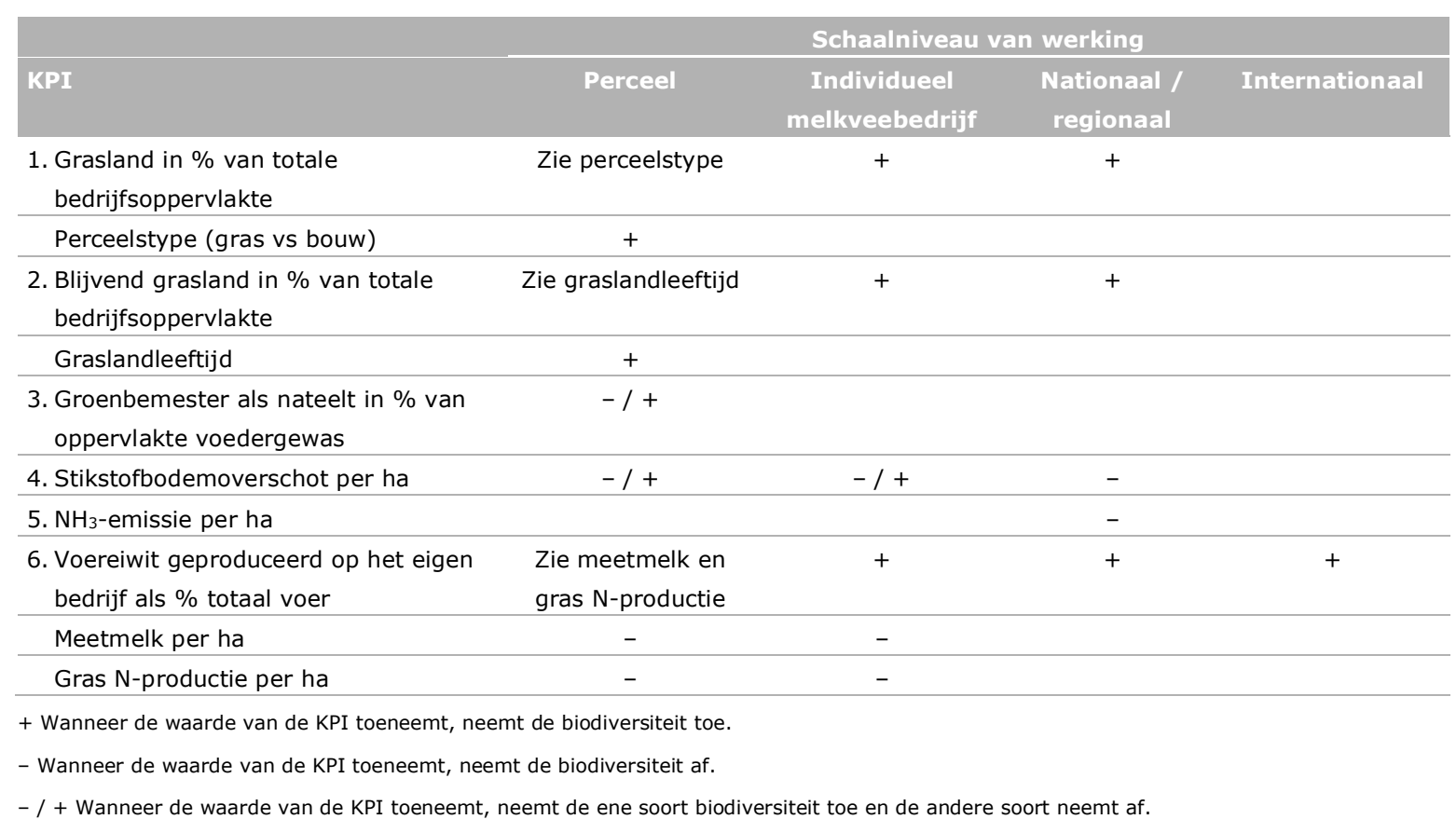




\section{$2 \quad$ Werkwijze}

\section{$2.1 \quad \mathrm{KPI}{ }^{\prime} \mathrm{s}$}

Voor dit onderzoek zijn de KPI's uit Zijlstra et al. (2017) overgenomen, aangevuld met de KPI's die relevant zijn op perceelsniveau zoals beschreven in paragraaf 1.4 .

1. Grasland in \% van totale bedrijfsoppervlakte van de totale bedrijfsoppervlakte - Perceelstype (gras- of bouwland)

2. Blijvend grasland in \% van totale bedrijfsoppervlakte van de totale bedrijfsoppervlakte - Graslandleeftijd

3. Groenbemester als nateelt in \% van oppervlakte voedergewas

4. Stikstofbodemoverschot per ha zoals berekend in de KringloopWijzer

5. $\mathrm{NH}_{3}$-emissie per ha, zoals berekend in de KringloopWijzer

6. Voereiwit geproduceerd op het eigen bedrijf als \% totaal voer

- Meetmelk per ha

- Gras N-productie per ha

\subsection{Selectie onderzoeksbedrijven}

Voor het selecteren van melkveebedrijven is gebruikgemaakt van het Bedrijveninformatienet van Wageningen Economic Research. ${ }^{4}$ In het Bedrijveninformatienet zijn de KPI's op basis van KringloopWijzer en aanvullende informatie van deze bedrijven beschikbaar. Omdat bedrijfsoverstijgende factoren in belangrijke mate bepalen wat de maximaal haalbare biodiversiteit is (zie ook Erisman et al., 2014) en op basis van advies van Zijlstra et al. (2017), is gekozen voor de stratificatie van de bedrijven op basis van:

- 3 grondsoorten (zand, klei en veen);

- 3 intensiteitsklassen (melkproductie per hectare) volgend op de spreiding in het Informatienet: $<13.000 \mathrm{~kg}$ melk per ha; $13.000-16.000 \mathrm{~kg}$ melk per ha; $>16.000 \mathrm{~kg}$ per melk per ha;

- 4 'biodiversiteitsklassen' op basis van de score op de huidige KPI's en de indeling in 4 kwadranten naar gelang de score op deze KPI's (Zijlstra et al., 2016).

Deze manier van selecteren van bedrijven is erop gericht om voldoende spreiding aan te brengen voor grondsoort, intensiteit en biodiversiteit. Op basis van de genoemde stratificatie zijn de 197 bedrijven uit het Bedrijveninformatienet in de 36 verschillende groepen ingedeeld (zie Bijlage 1, Tabel 10). Het aantal bedrijven in de groepen varieerde tussen 0 en 19. Er waren 2 groepen met 0 bedrijven. De eerste groep was veen, zeer intensief ( $>16.000 \mathrm{~kg}$ melk per ha) en met hoge score op biodiversiteit. De tweede groep was klei, matig intensief (13.000-16.000 kg melk per ha) en met lage score op biodiversiteit. Uit elk van de 34 groepen is één bedrijf telefonisch benaderd en vervolgens middels een brief met uitleg uitgenodigd om aan het onderzoek deel te nemen. Voor wat betreft de 2 groepen met 0 bedrijven, benaderden we uit de 'dichtstbijzijnde' groep een tweede bedrijf. Eén bedrijf was niet bereid om mee te doen aan het onderzoek en daarvoor in de plaats benaderden we een ander bedrijf uit dezelfde groep.

\subsection{Indicatoren voor biodiversiteit}

Het uitvoeren van een biodiversiteitsmeting op een melkveebedrijf is een tijdsintensief proces. Bij de keus van de te meten biodiversiteit, is daarom gezocht naar de balans tussen enerzijds relevantie en anderzijds financieel en organisatorisch haalbaar.

${ }^{4}$ Zie https://www.wur.nl/nl/Onderzoek-Resultaten/Onderzoeksinstituten/Data-Insights-1/Bedrijveninformatienet.htm 
Daarbij werden de volgende randvoorwaarden gehanteerd:

- De onderzoekers wilden een zo breed mogelijk aantal soorten planten en dieren meten. Biodiversiteit gaat immers over diversiteit en of er een relatie is met een KPI, kan variëren tussen soortgroepen.

- De onderzoekers wilden aansprekende soorten meten die herkenbaar zijn voor melkveehouders en consumenten.

- Het was wenselijk dat er een wetenschappelijk gevalideerde dan wel geaccepteerde methode was om de betreffende soorten te meten.

- Alle metingen op de bedrijven moesten door (steeds dezelfde) 2 daarvoor geselecteerde en getrainde experts gedaan worden om de hoeveelheid arbeid, de complexiteit van de logistiek en het aantal bezoekers op de bedrijven te beperken.

- De periode waarin het onderzoek zou plaatsvinden, moest zo kort mogelijk zijn. De manier waarop biodiversiteit zich uit (welke planten bloeien en welke insecten actief zijn) is immers deels afhankelijk van het seizoen.

Binnen deze randvoorwaarden is op basis van overleg met experts van het Louis Bolk Instituut, het Kenniscentrum voor Insecten, Smeding Advies en Coen ter Berg Advies ervoor gekozen om metingen te doen aan regenwormen, plantensoorten en kruipende en vliegende insecten op grasland (zie hieronder voor uitgebreide toelichting). Daarnaast is middels een vragenlijst gevraagd naar de aanwezigheid van bepaalde vogelsoorten (zwaluwen, mussen, weidevogels, roofvogels), hazen en reeën. Tenslotte zijn ook grondmonsters genomen om een aantal indicatoren voor bodembiodiversiteit te bepalen.

Een aantal indicatoren werd alleen onderzocht op grasland (insecten, wormen en plantensoorten), een deel op grasland én bouwland (grondmonsters voor Soil Health Index van Cornell University en bodembiologie van Eurofins) en een deel had betrekking op het hele bedrijf (vragen over vogels, hazen en reeën). Tabel 2 vat samen welke indicatoren op welk schaalniveau zijn onderzocht. De uitgebreidere beschrijving volgt daarna.

Tabel 2 Samenvatting van de gemeten indicatoren voor biodiversiteit

\begin{tabular}{|c|c|c|c|c|c|}
\hline \multicolumn{4}{|c|}{ Perceelsniveau } & \multicolumn{2}{|c|}{ Bedrijfsniveau } \\
\hline Bodemgezondheid & Regenwormen & Planten & Insecten & Vogels & Zoogdieren \\
\hline $\begin{array}{l}\text { - } \text { - Agatercapaciteit } \\
\text { - stabiliteit } \\
\text { - Eiwitindex } \\
\text { - Respiratie } \\
\text { - Organische stof } \\
\text { - Actieve koolstof } \\
\text { - Bio-index* } \\
\text { - Bodemleven } \\
\text { - Bodemstructuur } \\
\text { - Beworteling }\end{array}$ & $\begin{array}{l}\text { - Aantal wormen } \\
\text { - Aantal soorten } \\
\text { wormen } \\
\text { - Wormbiomassa } \\
\text { - Gewicht per } \\
\text { worm }\end{array}$ & $\begin{array}{l}\text { - Aantal } \\
\text { plantensoorten } \\
\text { - Aantal } \\
\text { grassoorten } \\
\text { - Aantal } \\
\text { kruidensoorten }\end{array}$ & $\begin{array}{l}\text { - Aantal } \\
\text { insectensoorten } \\
\text { zuigmethode } \\
\text { - Aantal insecten } \\
\text { zuigmethode } \\
\text { - Aantal insecten } \\
\text { plakvallen } \\
\text { - Aantal insecten } \\
\text { 4-10 mm } \\
\text { plakvallen }\end{array}$ & $\begin{array}{l}\text { - Aantal soorten } \\
\text { insecteneters } \\
\text { - Aantal soorten } \\
\text { wormeneters } \\
\text { - Aantal soorten } \\
\text { roofvogels } \\
\text { - Totaal aantal } \\
\text { soorten vogels }\end{array}$ & $\begin{array}{l}\text { - Aantal } \\
\text { hazen } \\
\text { - Aantal } \\
\text { reeën }\end{array}$ \\
\hline
\end{tabular}

* Bio-index is de combinatie van de voorgaande 6 indicatoren, allen onderdeel van de soil health index

\section{Keuze van de monsterlocaties}

Aan de melkveehouder is gevraagd om een gemiddeld perceel productiegras (gemiddeld met betrekking tot aantal plantensoorten, hierna 'gras gemiddeld' genoemd), een perceel productiegras met meer dan gemiddeld aantal plantensoorten (hierna 'gras divers' genoemd) en een perceel bouwland aan te wijzen. De graspercelen moesten productiegraspercelen zijn. Dus natuurpercelen of percelen met bijvoorbeeld uitgestelde maaidatum zijn buiten beschouwing gelaten. Het bouwland betrof altijd een snijmaisperceel.

\section{Bodemgezondheid}

Met bodemgezondheid bedoelen we het goed biologisch functioneren van de bodem, hetgeen zich uit in ziektewering, een goede productie, $\mathrm{CO}_{2}$-vastlegging en bodembiodiversiteit. Bodemgezondheid wordt bepaald door biologische, fysische en chemische kenmerken. We hebben gebruikgemaakt van 2 aanbieders van testen voor bodemgezondheid. De eerste is Cornell University uit Ithaca, New York. 
Cornell University heeft een Soil Health Index (SHI) ontwikkeld (Moebius-Clune et al., 2017). Deze SHI bevat onder andere de volgende metingen: bodemtextuur, ${ }^{5}$ watercapaciteit, ${ }^{6}$ aggregaatstabiliteit, ${ }^{7}$ organische stof, bodemeiwit, ${ }^{8}$ respiratie, ${ }^{9}$ actieve koolstof, ${ }^{10}$ de zuurgraad van de bodem $(\mathrm{pH})$ en het fosfor- en kaliumgehalte. Op basis van een aantal van de afzonderlijke metingen werden een bio-index (exclusief chemische metingen) en een totaalscore (inclusief chemische metingen) berekend. De tweede aanbieder waarvan we gebruikmaakten, is Eurofins uit Wageningen. Eurofins biedt een test 'bodembiologie' aan. Dat is de hoeveelheid potentieel anaeroob mineraliseerbare stikstof. De monstername voor de beide laboratoria ging als volgt. Per perceel (gras gemiddeld, gras divers en bouwland) zijn met een grondboor al lopend door het perceel 50 'steken' van 0-10 cm diep genomen. Deze 50 steken zijn in een emmer gemengd. Samen wogen deze 50 steken ongeveer $2 \mathrm{~kg}$. Hieruit zijn 2 monsters genomen en verstuurd naar respectievelijk Cornell en Eurofins.

De bodemstructuur is bepaald via een visuele beoordeling (Koopmans et al., 2005), aan de hand van gestandaardiseerde foto's van kluiten. Per bedrijf werden op een gemiddeld-grasperceel en op een

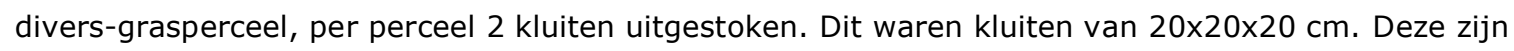
op een vuilniszak gelegd en doormidden gebroken. Hierdoor werd de structuur (het breukvlak) van de binnenzijde zichtbaar in plaats van het gladde snijvlak veroorzaakt door de spade. De kluiten zijn gefotografeerd met een liniaal in beeld. De foto's zijn ter beoordeling voorgelegd aan Marleen Zanen (bodemkundige bij het LBI). Deze gaf de kluiten een rapportcijfer voor structuur en voor beworteling.

\section{Regenwormen}

Er zijn meerdere redenen om regenwormen mee te nemen in een onderzoek naar biodiversiteit. Op een melkveebedrijf zijn regenwormen belangrijk voor de afbraak van organische stof, beschikbaar maken van nutriënten, behoud van bodemstructuur, menging van gronddeeltjes, waterinfiltratie, beworteling en uiteindelijk voor gewasopbrengst. Ook zijn wormen voedsel voor bovengrondse fauna. De aanwezigheid van regenwormen, welke soorten dat zijn en hoe groot ze zijn, is ook een weerspiegeling van de bodemkwaliteit en van het beheer door de ondernemer (Van Eekeren et al., 2014). Op 2 graslandpercelen per bedrijf (gras gemiddeld en gras divers) zijn per perceel 2 plaggen van 20x20x20 cm gestoken. Deze zijn in een vuilniszak gedaan en dezelfde dag in een koeling bewaard. De dag daarna of maximaal 4 dagen later zijn de wormen handmatig uit de plaggen gehaald, gedood en bewaard in een alcoholoplossing. Daarna werden ze gedetermineerd, gewogen en geteld. Per plag zijn de volgende gegevens verzameld en in de database opgenomen: totaal aantal wormen, aantal volwassen wormen, aantal juveniele wormen, aantal strooisel bewonende wormen, aantal bodem bewonende wormen, aantal pendelaars, aantal soorten wormen, gewicht per worm en totale wormenbiomassa.

\section{Planten}

We keken naar soorten die midden in productiegraslandpercelen aanwezig waren. Op elk van de 2 graslandpercelen (gras gemiddeld en gras divers) is op 4 plekken van 0,25 $\mathrm{m}^{2}$ gekeken welke soorten gras en andere planten er stonden. Daarvoor gebruikten we een kunststof ring die we 4 keer gooiden. Het deel binnen de ring is beoordeeld. De aanwezige soorten zijn opgeschreven. Soorten die we niet meteen herkenden of die te veel tijd kostten om in het veld te determineren, namen we mee en determineerden we later. Per perceel namen we in de database op: aantal soorten grassen, aantal soorten kruiden, aantal soorten klavers en totaal aantal soorten.

\section{Insecten}

Insecten zijn voedsel voor bijvoorbeeld weidevogelkuikens, zwaluwen en vleermuizen. Ze zijn ook een weerspiegeling van het graslandbeheer en de aanwezigheid van bepaalde vegetatietypen en landschapselementen. Insecten maten we op 2 verschillende manieren. De ene manier, met een tot insectenzuiger omgebouwde bladblazer, is afgeleid van de methode beschreven door Kuiper (2015).

\footnotetext{
5 Bodemtextuur is de verhouding tussen klei-, zand- en leemdeeltjes in de grond. Deze verhouding bepaalt onder andere hoeveel vocht en organische stof een bodem kan bevatten.

6 Watercapaciteit is de hoeveelheid water voor gebruik door planten die een grondmonster kan opslaan.

7 Aggregaatstabiliteit is een maat voor het intact blijven van gronddeeltjes (=aggregaten) als er waterdruppels op vallen.

8 Bodemeiwit is dat deel van de organische stof dat organisch gebonden stikstof (N) bevat. Deze stikstof is na mineralisatie door micro-organismen geschikt voor opname door planten.

9 Respiratie is een maat voor de metabolische activiteit van de micro-organismen.

${ }^{10}$ Actieve koolstof is een maat voor dat deel van de organische stof dat micro-organismen als voedsel kunnen gebruiken.
} 
De andere manier werkt met plakvallen en is ontwikkeld door EIS Kenniscentrum Insecten in samenwerking met Naturalis Biodiversity Centre en het Louis Bolk Instituut (Michels, 2017).

De zuigmethode pasten we toe op 2 graslandpercelen (gras gemiddeld en gras divers) en per perceel op 4 plekken. Een kunststof ring is gebruikt om telkens een oppervlak van 0,25 $\mathrm{m}^{2}$ te bemonsteren. De insecten deelden we in in de soortgroepen 'kevers', 'vliegende insecten', 'spinnen \& hooiwagens' of 'anders, $\mathrm{nl}$...'. Hun kop-staartlengte is ingeschat en ze zijn ingedeeld in één van de groottecategorieën $<4 \mathrm{~mm}, 4-7 \mathrm{~mm}, 7-12 \mathrm{~mm}$ en $>12 \mathrm{~mm}$.

De plakvalmethode is ingezet in een speciaal geplande meetweek. Het moment in het seizoen en de weersomstandigheden moesten voor alle metingen zoveel mogelijk hetzelfde zijn. We wachtten een week met droog en stabiel weer af (3-7 juli 2017), waarin we op alle 36 bedrijven op 2 graslandpercelen (gras gemiddeld en gras divers) de plakvallen plaatsten. Per perceel zijn 10 gele plakvallen geplaatst. Na 48 uur zijn de plakvallen opgehaald en in de diepvries bewaard, alvorens verdere verwerking is gedaan. De verwerking bestond uit gestandaardiseerd fotograferen van beide zijden van alle plakvallen liggend op een blauwe achtergrond. De foto's zijn opgestuurd naar Kenniscentrum EIS waar alle foto's zijn gescand met behulp van een computerprogramma. Het aantal insecten per plakval is weergegeven in de groottecategorieën: $<4 \mathrm{~mm}, 4-10 \mathrm{~mm}$ en $>10 \mathrm{~mm}$. Hierbij is onderscheid gemaakt tussen noord- en zuidzijde van de plakvallen. Deze gegevens zijn opgenomen in de database. In de rapportage is het totaal aantal insecten van de noord- en zuidzijde opgenomen. Omdat grashoogte van invloed zou kunnen zijn op de aanwezigheid van insecten, is deze bij het plaatsen gemeten en in de database gezet.

\section{Vogels}

Vogels zijn een brede, zichtbare en aansprekende groep dieren. Verschillende factoren zijn bepalend voor hun aanwezigheid. Ten eerste is het landschap bepalend voor de aanwezigheid van bepaalde soorten in het gebied. Weidevogels hebben een voorkeur voor open gebied en broeden niet in gebieden met bomen en bosjes. Ten tweede heeft de melkveehouder invloed op de aanwezigheid van weidevogels door percelen later te maaien (waarmee hij nesten spaart) of door bijvoorbeeld ruige stalmest of de dikke fractie van gescheiden drijfmest te gebruiken (gunstig om verschillende redenen, onder andere voedselbeschikbaarheid (Deru et al., 2016)). Zwaluwen zijn weer gebaat bij bepaalde kenmerken van de bebouwing en bovenal of ze, als ze er eenmaal zitten, getolereerd worden door de veehouder. $\mathrm{Er}$ is aan de melkveehouders gevraagd of bepaalde vogels aanwezig waren (ja of nee) op het bedrijf en hoeveel nesten er waren. Vogels waarnaar we vroegen, zijn de spreeuw, scholekster, kievit, grutto, tureluur en wulp (categorie: wormen etende vogels); boerenzwaluw, huiszwaluw, huismus, ringmus en gele kwikstaart (categorie: insecten etende vogels); torenvalk, kiekendief, kerkuil, steenuil en ransuil (categorie: roofvogels) en patrijs en kwartel (categorie: overig). De antwoorden zijn per categorie vogels in de database gezet: aanwezigheid van één of meer soorten uit de betreffende categorie ( $j a$ of nee) en aantal soorten aanwezig uit de betreffende categorie. Voor de uiteindelijke analyse is gerekend met het aantal soorten vogels binnen de volgende categorieën: wormeneters, insecteneters, roofvogels en totaal (som van het aantal soorten uit de drie categorieën).

\section{Zoogdieren}

We kozen voor twee makkelijk herkenbare soorten: hazen en reeën. Hun aanwezigheid wordt deels bepaald door landschapskenmerken. Reeën willen graag bosjes hebben om te schuilen. Hazen lijken gebaat bij een niet al te intensief graslandbeheer en enige variatie in het landschap en tussen percelen (Smith et al., 2004). Aan de melkveehouders is voor beide diersoorten gevraagd of ze deze wel eens op hun land zagen (ja of nee) en zo ja, in welke aantallen maximaal. De maximale aantallen van beide diersoorten zijn in de database opgenomen.

\subsection{Draaiboek inventarisatie biodiversiteit}

Voor de inventarisatie van biodiversiteit op de 36 bedrijven is een draaiboek gemaakt. Dit bestond uit afspraken voor de uitvoerende onderzoekers, de vragenlijst voor de melkveehouder, instructieformulieren, invulformulieren, afspraken over het coderen van monsters en een checklist voor de acties tijdens het bedrijfsbezoek. Op basis van het conceptdraaiboek bedrijfsbezoek 'oefenden' de onderzoekers alle metingen op een graslandperceel van een melkveehouder in Driebergen, die 
verder niet bij het onderzoek betrokken was. Het doel hiervan was om te kijken of alles duidelijk was en af te stemmen op dezelfde te hanteren werkwijze. Vervolgens bezochten de onderzoekers samen de eerste 2 bedrijven om de werkwijze nog beter te kunnen standaardiseren.

De bedrijfsbezoeken verliepen als volgt. Als eerste hielden ze een interview met de melkveehouder. In dit interview zijn de vragen uit de vragenlijst beantwoord. De melkveehouder is daarnaast gevraagd percelen te selecteren die in aanmerking komen voor de bemonstering: een gemiddeld-grasperceel, een divers-grasperceel en indien aanwezig een bouwlandperceel. Daarna zijn de metingen verricht. Na afloop zijn de grondmonsters en de wormenplaggen in de koeling gezet van het laboratorium van het Louis Bolk Instituut (LBI) in Driebergen. Het laboratorium van het LBI verzorgde de afhandeling en de verzending van de monsters naar Cornell University en Eurofins. Ook heeft het LBI-laboratorium het onderzoek naar de wormen uitgevoerd.

\subsection{Statistische analyse}

Alle resultaten zijn ingevoerd in een Excel-database: de antwoorden van de boeren op de vragen, de resultaten van de metingen in het veld, de uitslagen van de verschillende laboratoria en de bodemkundige en de KPI-gegevens uit de database van het Bedrijveninformatienet van Wageningen Economic Research. Aan de hand van ANOVA's ${ }^{11}$ is het effect van grondsoort (zand, klei en veen) en type perceel (gras gemiddeld, gras divers en bouwland) op de gemiddelde scores van de biodiversiteitsindicatoren onderzocht. Aan de hand van correlaties ${ }^{12}$ is de relatie tussen biodiversiteit, omgeving, management, bodem en KPI's onderzocht. Op basis van de ANOVA's en de correlaties is uit de veelheid aan biodiversiteitsindicatoren een aantal 'representatieve/aansprekende/herkenbare' indicatoren van de gemiddeld-graspercelen geselecteerd (Tabel 2) om te onderzoeken of ze een relatie hadden met de KPI's en zo ja, welke. Deze relaties werden berekend met regressieanalyses, ${ }^{13}$ waarbij grondsoort en omgeving als covariabele ${ }^{14}$ werden meegenomen. Afhankelijk van het niveau van de waarnemingen (perceelsniveau of bedrijfsniveau) werden de modellen aangepast. Bijvoorbeeld op bedrijfsniveau werden de KPI's grasland in \% van totale bedrijfsoppervlakte en blijvend grasland in \% van totale bedrijfsoppervlakte meegenomen in de regressieanalyse. Deze KPI's zeggen op (grasland)perceelsniveau echter niet zoveel en zijn daarom vervangen door leeftijd van het graslandperceel (= aantal jaar sinds herinzaai). Zie paragraaf 1.4 voor meer uitleg over indicatoren op bedrijfs- en perceelsniveau. Er zijn verschillende regressiemodellen geschat. Op perceelsniveau werden in regressiemodel 1 (Bijlage 4; Tabel 17) het \% lutum en \% organische stof en de interacties met de KPI's meegenomen. In regressiemodel 2 (Tabel 18) werden deze bodemparameters vervangen door de categorieën klei, zand en veen. Op bedrijfsniveau werden in regressiemodel 3 (Tabel 19) het \% van het bedrijfsoppervlak dat geclassificeerd is als veen, klei en zand (op basis van de database van het Bedrijveninformatienet) meegenomen. In regressiemodel 4 (Tabel 20) werden deze vervangen door de classificatie op bedrijfsniveau (klei, zand of veen).

De regressiemethode was de stepwise backward regressie, uitgevoerd met IBM SPSS Statistics 23. Voor deze methode is gekozen omdat uit de ANOVA's bleek dat KPI's en grondsoort sterk met elkaar samenhangen en om een set van KPI's en omgevingsfactoren te selecteren die significant bijdragen aan de verklaring van de variatie. Echter, de interpretatie van deze regressieanalyse behoeft de nodige voorzichtigheid (Woolridge, 2016). Daarom hebben we steeds de resultaten van de verschillende regressiemodellen geïnterpreteerd in samenhang met de correlaties over alle bedrijven en binnen de grondsoorten.

\footnotetext{
${ }^{11}$ Een ANOVA (ANalysis Of VAriance) is een toets die gebruikt wordt om vast te stellen of de gemiddelden van een bepaalde variabele (bijvoorbeeld aantal regenwormen) significant van elkaar verschillen, indien die in meer dan 2 'groepen' (bijvoorbeeld de grondsoorten zand, klei en veen) onderzocht is. De toets geeft alleen aan of er verschil is en geeft geen verklaring voor die verschillen.

${ }^{12}$ Een correlatie is een berekening van de mate van samenhang tussen 2 variabelen in 2 reeksen van metingen, bijvoorbeeld bodemoverschot stikstof en het aantal regenwormen.

${ }^{13}$ Met regressieanalyse probeer je de waargenomen spreiding in een afhankelijke variabele te verklaren met behulp van onafhankelijke verklarende variabelen, bijvoorbeeld om de samenhang tussen de afhankelijke variabele en één of meer verklarende variabelen te onderzoeken.

${ }^{14}$ Een covariabele is een mogelijk voorspellende variabele die het effect kan beïnvloeden van de relatie tussen een onafhankelijke en een afhankelijke variabele en die dus het inzicht in de relatie die je wilt onderzoeken, kan verstoren. Door variabelen als 'covariabele mee te nemen', worden de berekeningen zo gedaan dat het effect ervan wordt verwijderd.
} 


\section{Resultaten}

\subsection{Verschillen tussen grondsoorten}

De 36 geselecteerde melkveebedrijven lagen verspreid over Nederland, met uitzondering van de provincies Zeeland en Limburg. De Excel database bevat informatie van 525 indicatoren op bedrijfsniveau en 156 indicatoren op perceelsniveau. In Figuur 1 staan de range en het gemiddelde van de KPI's weergegeven voor alle bedrijven $(n=36)$ en per grondsoort $(n=12$ op klei; $n=13$ op veen; $n=11$ op zand). Een beperkt deel van de bedrijven had groenbemesters: $n=8$ op klei, $n=5$ op veen en $\mathrm{n}=9$ op zand. Er bleken grote verschillen tussen grondsoorten voor wat betreft het aandeel blijvend grasland, graslandleeftijd, groenbemester als nateelt in \% van oppervlakte voedergewas en stikstofbodemoverschot.

Aandeel blijvend grasland

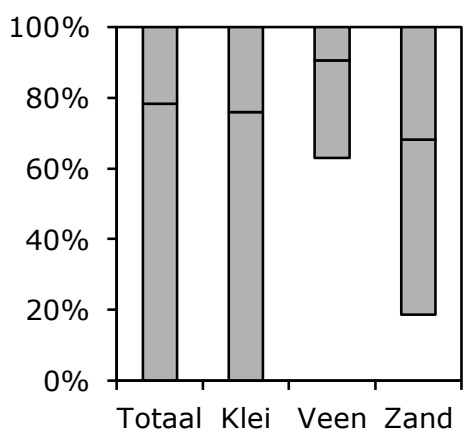

Stikstofbodemoverschot

( $k g$ per ha)

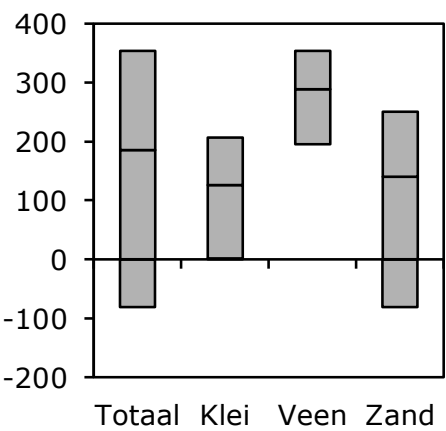

Meetmelk per ha

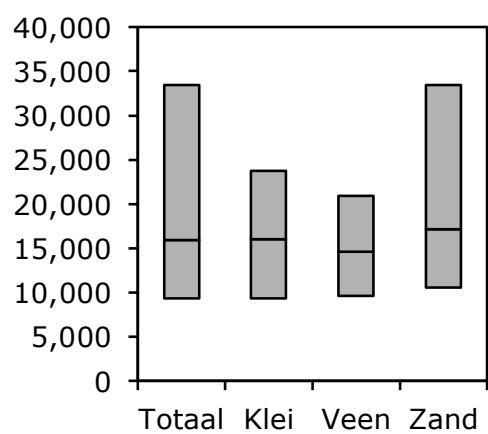

Graslandleeftijd (jaar)

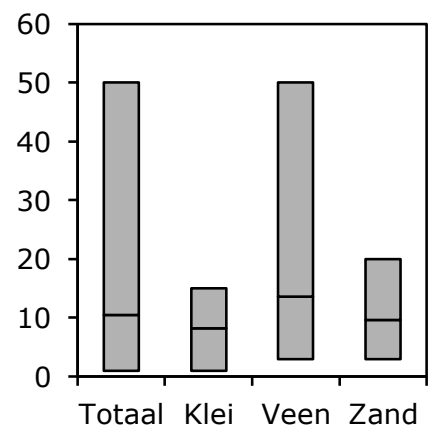

$\mathrm{NH}_{3}$-emissie

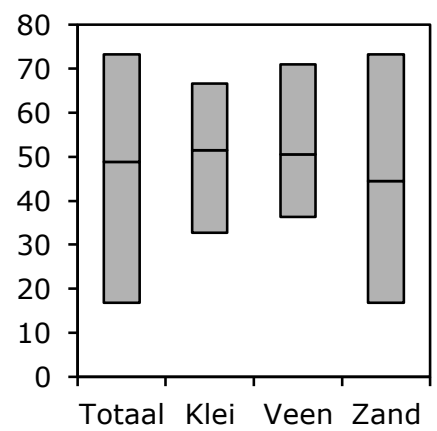

Grasopbrengst $N$ ( $k g$ per ha)

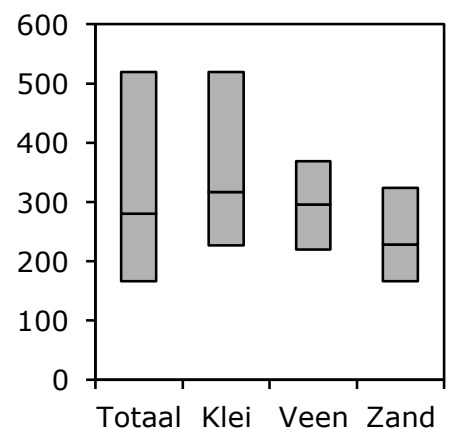

groenbemester als nateelt in \% van oppervlakte voedergewas

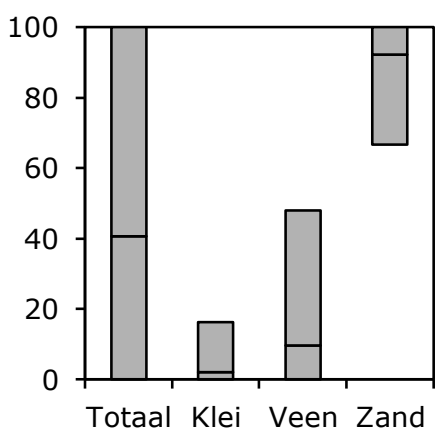

Aandeel eigen voer $N$

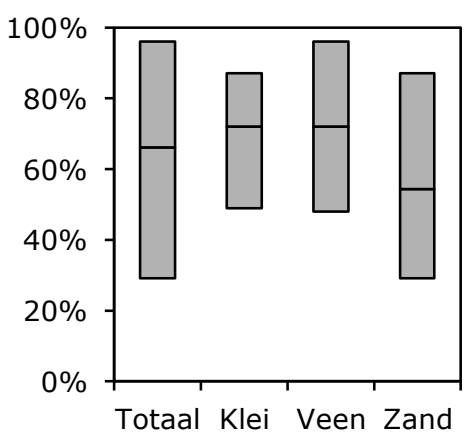

Figuur 1 Overzicht van minimum, gemiddelde (middenlijn in staven) en maximum waardes voor de KPI's over alle bedrijven $(n=36)$ en per grondsoort 


\subsection{Bodembiodiversiteit}

\subsubsection{Effect van grondsoort en perceelstype}

Voor alle bodemindicatoren met uitzondering van bodemstructuur en beworteling was er een significant effect van grondsoort en perceelstype (gras gemiddeld, gras divers of bouwland). Zie Tabel 12 in Bijlage 3, Figuur 2 en Figuur 3 voor meer details.

\section{Watercapaciteit}

De gemiddelde watercapaciteit in gram water per gram grond is het hoogst op klei $(0,28-0,35)$ en veen $(0,25-0,34)$ en het laagst op zand $(0,13-0,17)$. Kijkend naar perceelstypen is de capaciteit het hoogst op gras gemiddeld $(0,17-0,32)$ en gras divers $(0,16-0,35)$ en het laagst op bouwland $(0,13-0,28)$.

\section{Aggregaatstabiliteit}

De aggregaatstabiliteit (in \%) is het hoogst op klei (49-82) en veen (73-95) en het laagst op zand (36-73). Kijkend naar perceelstypen is hij het hoogst op gras gemiddeld (71-92) en gras divers (68-95) en het laagst op bouwland (33-73).

\section{Eiwitindex}

De eiwitindex (in mg per g droge stof) is het hoogst op veen (31-39) en het laagst op klei (8-17) en zand (12-19). Kijkend naar perceelstypen is hij het hoogst op gras gemiddeld (16-35) en gras divers (15-40) en het laagst op bouwland (4-31).

\section{Respiratie}

De respiratie (in $\mathrm{mg} \mathrm{CO} 2$ per $\mathrm{g}$ droge stof) is het hoogst op klei $(0,8-1,9)$ en veen $(0,9-1,7)$ en het laagst op zand $(0,4-1,0)$. Kijkend naar perceelstypen is hij het hoogst op gras gemiddeld $(1,0-1,7$ en gras divers $(0,9-1,9)$ en het laagst op bouwland $0,4-0,9)$.

\section{Organische stof}

Het organische-stofgehalte (in \%) is het hoogst op veen (18-22), gevolgd door klei (6-10) en het laagst op zand (3-5). Kijkend naar perceelstypen is hij het hoogst op gras gemiddeld (5-22) en gras divers (4-22) en het laagst op bouwland (3-18).

\section{Actieve koolstof}

De actieve koolstof (in ppm) is het hoogst in klei (665-1027) en veen (994-1075) en het laagst in zand (510-761). Kijkend naar perceelstypen is hij het hoogst in gras gemiddeld (690-1046) en gras divers (761-1075) en het laagst in bouwland (510-994).

\section{Bio-index}

De bio-index, een geïndexeerde score (variërend van 0-100) op basis van bovenstaande 6 indicatoren, is het hoogst op klei (72-98) en veen (89-97) en het laagst op zand 54-82). Kijkend naar perceelstypen, is hij het hoogst op gras gemiddeld (82-97) en gras divers (82-98) en het laagst op bouwland (54-89).

\section{Eurofins bodemleven}

De Eurofins bodemlevenindicator (potentieel anaeroob mineraliseerbare $\mathrm{N}$ in $\mathrm{mg}$ per $\mathrm{kg}$ ) is het hoogst in klei (80-195) en veen (167-322) en het laagst in zand (52-133). Kijkend naar perceelstypen is hij het hoogst in gras divers (133-322), gevolgd door gras gemiddeld (127-310) en het laagst in bouwland (52-167). 


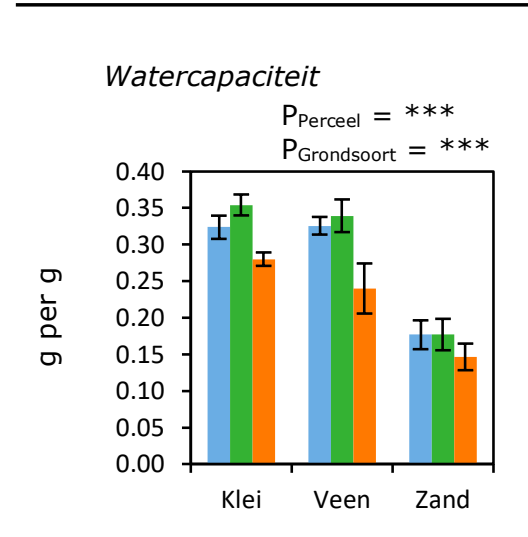

Aggregaatstabiliteit

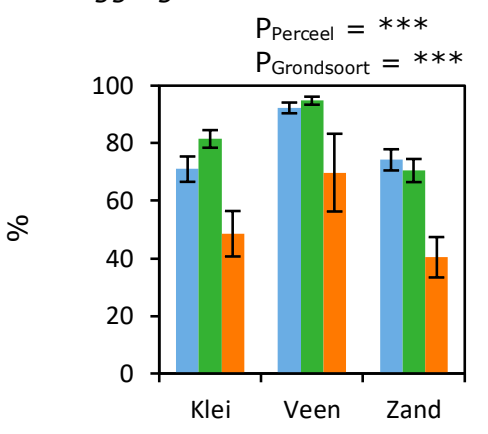

Organische stof

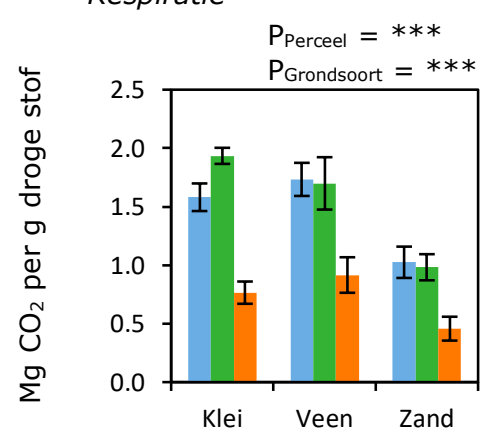

Bio-index

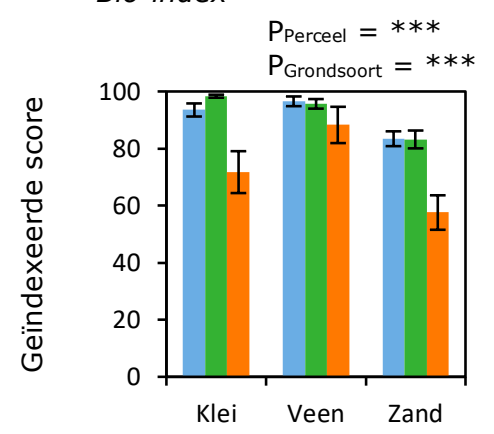

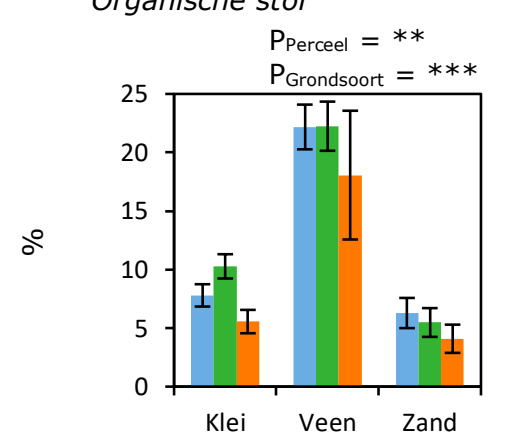

Eurofins bodemleven

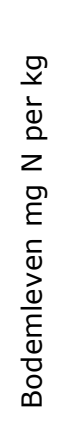

Eiwitindex

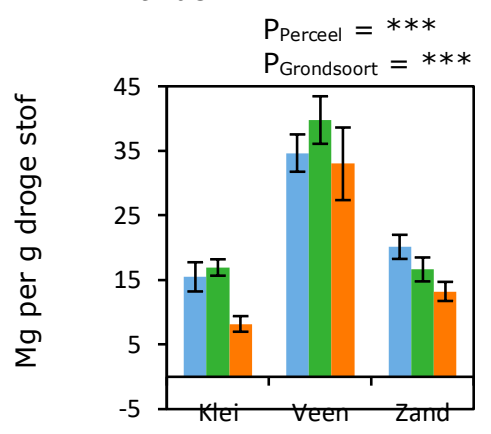

Actieve koolstof

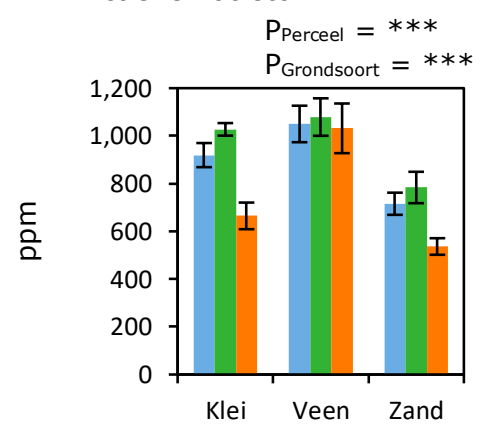

Figuur 2 Grafische weergave van de verschillen tussen grondsoorten en perceelstypen voor 6 afzonderlijke fysische en biologische indicatoren uit de Soil Health Index, de bio-index en Eurofins bodemleven 


\section{Bodemstructuur}

De gemiddelde bodemstructuur, uitgedrukt in een score per rapportcijfer (1-10) lijkt beter op klei $(7,0-7,1)$ en veen $(7,3-7,6)$ dan op zand $(6,4-7,1)$, maar de verschillen zijn niet significant. Ook de ogenschijnlijke verschillen tussen gras gemiddeld $(7,0-7,6)$ en gras divers $(6,4-7,3)$ zijn niet significant. Deze indicator is niet beoordeeld op bouwland.

\section{Beworteling}

De gemiddelde beworteling, uitgedrukt in een score per rapportcijfer (1-10) lijkt beter op veen $(7,3-7,6)$ dan op klei $(7,1)$ en zand $(6,9-7,1)$, maar de verschillen zijn niet significant. Ook de ogenschijnlijke verschillen tussen gras gemiddeld $(7,1-7,6)$ en gras divers $(6,9-7,3)$ zijn niet significant. Deze indicator is niet beoordeeld voor bouwland.

Bodemstructuur $0-20 \mathrm{~cm}$

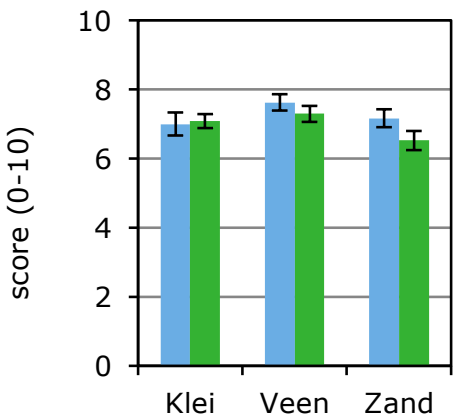

Beworteling 0-20 cm

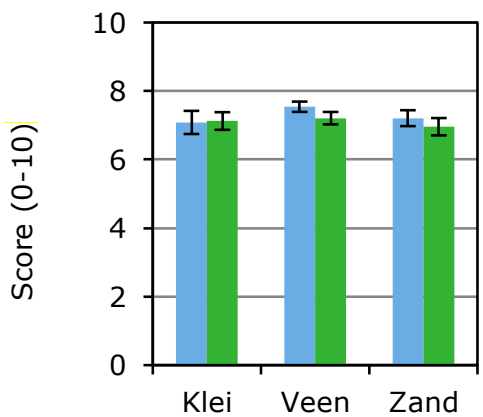

- Gras-gem

Gras-divers

Figuur 3 Grafische weergave van de bodemstructuur en de beworteling in de bovenste $20 \mathrm{~cm}$ van de bodem

\subsubsection{Verbanden met KPI's}

In Tabel 3 staan de relaties tussen de KPI's en de bodembiodiversiteitsindicatoren op basis van de correlaties samengevat. Voor meer informatie zie Bijlage 3. Er was een overwegend positief verband met de graslandleeftijd, stikstofbodemoverschot en de grasopbrengst. Er zijn geen significante verbanden met meetmelk per ha.

\section{Tabel 3 Samenvatting van de relaties tussen KPI's en bodembiodiversiteit}

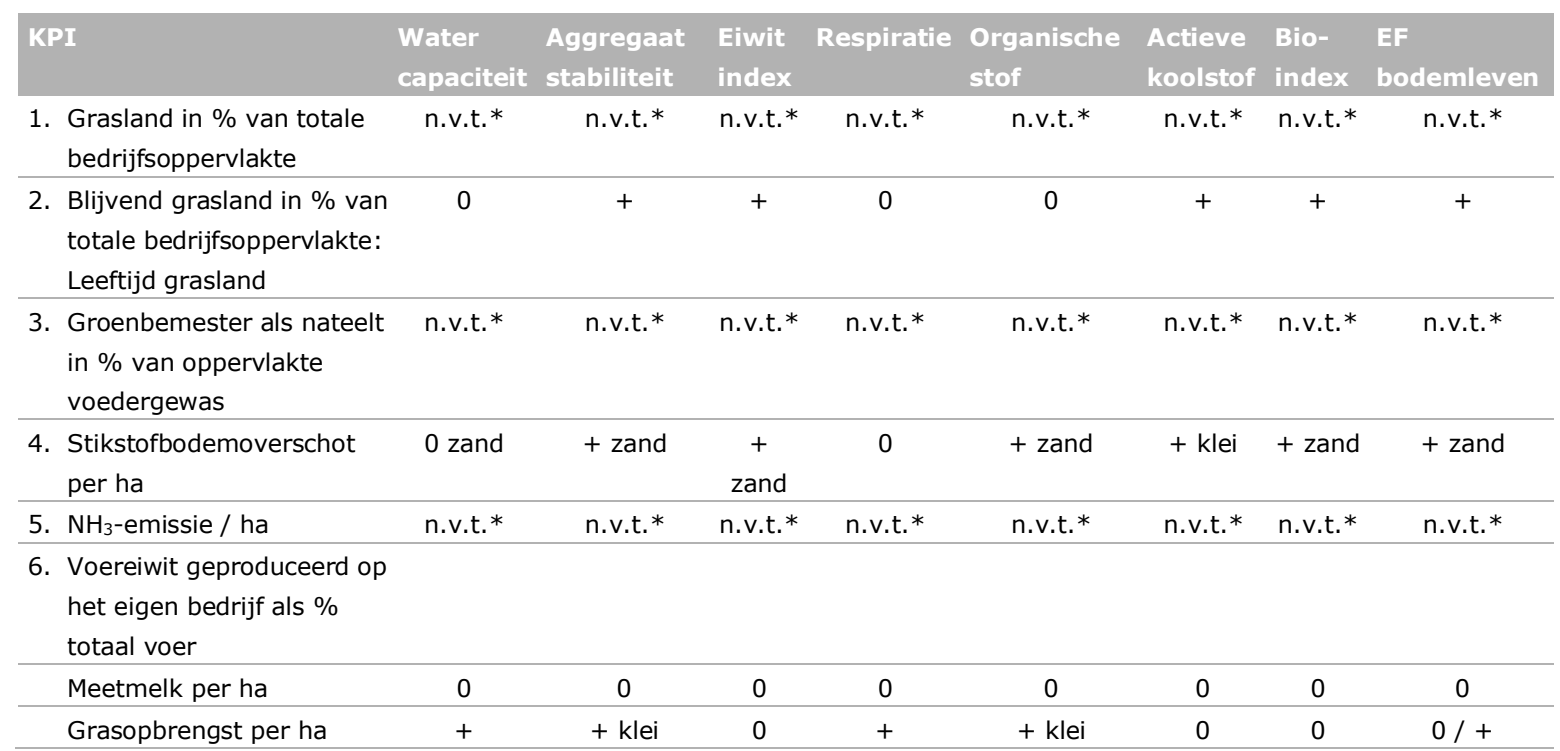

* niet van toepassing: bij de correlatieanalyse is alleen gekeken naar verbanden met de KPI's of afgeleide KPI's op de relevante schaal van de indicatoren, in dit geval perceelsniveau (zie ook Tabel 1).

$+\mathrm{Er}$ is positief verband; - Er is negatief verband; $0 \mathrm{Er}$ is geen verband. 


\subsection{Regenwormen}

\subsubsection{Effect van grondsoort en perceelstype}

In Bijlage 3 (Tabel 11) staan de details met betrekking tot het aantal wormen, het aantal soorten wormen, de hoeveelheid wormbiomassa en het gewicht per worm. Figuur 4 laat zien dat er voor het merendeel van de indicatoren geen significante verschillen zijn tussen perceelstypen of grondsoorten.

Aantal wormen

Er was een trend $(P=0,16)$ dat in de divers-graspercelen (354-799) meer wormen werden geteld dan in de gemiddeld-graspercelen (411-627). Het aantal wormen per $\mathrm{m}^{2}$ was het hoogste op veen

(627-799), gevolgd door klei (411-521) en zand 354-355).

\section{Aantal soorten wormen}

Het aantal soorten wormen verschilde niet significant tussen de grondsoorten en niet tussen de perceelstypen. Gemiddeld werden tussen de 3,3 en 4,5 soorten wormen geteld.

\section{Wormenbiomassa}

De gemiddelde wormenbiomassa ( $\mathrm{g}$ per $\mathrm{m}^{2}$ ) verschilde niet significant tussen de grondsoorten en niet tussen de perceelstypen. Gemiddeld werden tussen de 87 en 143 gram wormen per m² geteld.

\section{Wormgewicht}

Het gemiddelde gewicht per worm verschilde significant tussen de grondsoorten: op zand waren de wormen het zwaarst $(0,26-0,29$ gram), gevolgd door klei $(0,22-0,24$ gram) en veen $(0,18-0,19)$. Er waren geen verschillen tussen perceelstypen.

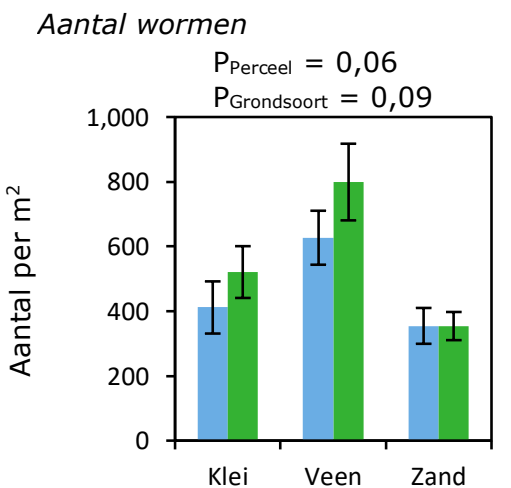

Aantal soorten wormen

Wormenbiomassa

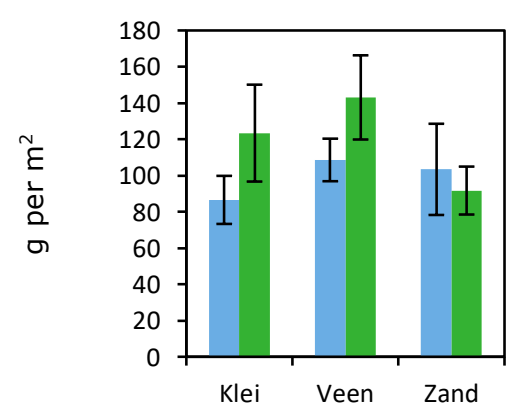

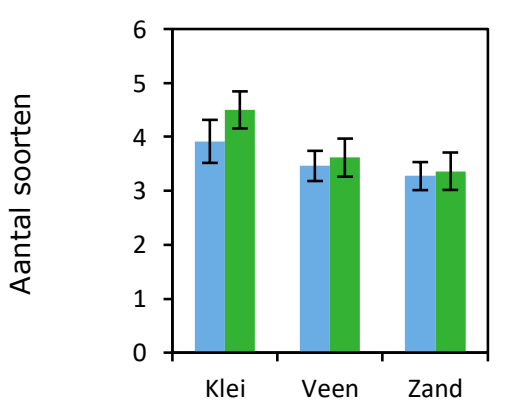

Wormgewicht

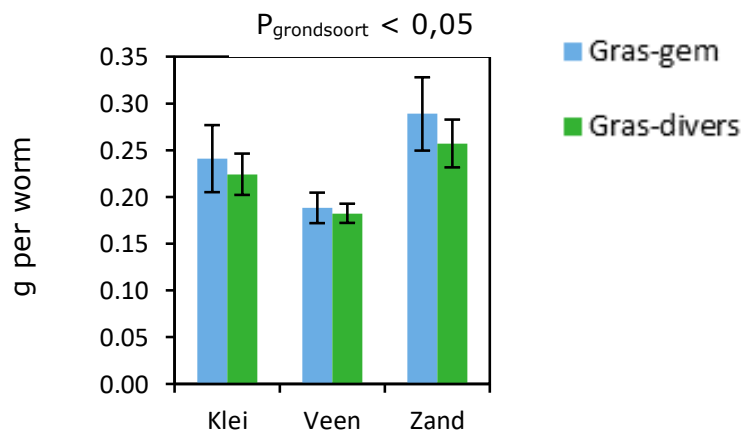

Figuur 4 Het effect van perceelstype en grondsoort op de wormenindicatoren 


\subsubsection{Verbanden met KPI's}

In Tabel 4 zijn de relaties tussen de KPI's en de wormenindicatoren samengevat op basis van de correlaties en de regressieanalyses (voor details zie Bijlage 3, 4 en 5). Er was een overwegend positief verband tussen graslandleeftijd en het aantal wormen, het aantal soorten wormen en het gewicht per worm. Stikstofbodemoverschot liet alleen een positief verband zien met het gewicht per worm. Met de andere wormenindicatoren was er geen of een negatief verband. Het verband tussen meetmelk per ha en de wormenindicatoren was niet consistent. Grasopbrengst per ha liet wel een aantal positieve verbanden met wormenindicatoren zien.

Tabel 4 Samenvatting van de relaties tussen KPI's en biodiversiteit uitgedrukt in wormen indicatoren

\begin{tabular}{|c|c|c|c|c|}
\hline KPI & $\begin{array}{l}\text { Aantal } \\
\text { wormen }\end{array}$ & $\begin{array}{l}\text { Aantal soorten } \\
\text { wormen }\end{array}$ & Wormbiomassa & $\begin{array}{l}\text { Gewicht per } \\
\text { worm }\end{array}$ \\
\hline $\begin{array}{l}\text { 1. Grasland in \% van totale } \\
\text { bedrijfsoppervlakte }\end{array}$ & n.v.t.* & n.v.t.* & n.v.t.* & n.v.t.* \\
\hline $\begin{array}{l}2 \text { Blijvend grasland in \% van totale } \\
\text { bedrijfsoppervlakte: } \\
\text { Leeftijd grasland }\end{array}$ & + & + & 0 & + \\
\hline $\begin{array}{l}\text { 3. Groenbemester als nateelt in \% van } \\
\text { oppervlakte voedergewas }\end{array}$ & n.v.t. $*$ & n.v.t.* & n.v.t.* & n.v.t.* \\
\hline 4. Stikstofbodemoverschot per ha & 0 & $0 /-$ & $0 /-$ & + \\
\hline 5. $\mathrm{NH}_{3}$-emissie/ha & n.v.t.* & n.v.t.* & n.v.t.* & n.v.t.* \\
\hline \multicolumn{5}{|l|}{$\begin{array}{l}\text { 6. Voereiwit geproduceerd op het eigen } \\
\text { bedrijf als \% totaal voer }\end{array}$} \\
\hline Meetmelk per ha & + & inconsistent & $\begin{array}{l}\text { + zand } \\
\text { - veen }\end{array}$ & $\begin{array}{c}+ \text { veen } \\
\text { - zand en klei }\end{array}$ \\
\hline Grasopbrengst per ha & 0 & + zand en klei & + & + zand \\
\hline
\end{tabular}

\subsection{Graslandplanten}

\subsubsection{Effect van grondsoort en perceelstype}

De detailinformatie met betrekking tot graslandplanten staat in Bijlage 2 (Tabel 11). De resultaten worden geïllustreerd in Figuur 5. In de divers-graspercelen zagen we significant meer soorten planten (5,9-8,6 soorten) dan in gemiddeld-graspercelen (5,2-6,1 soorten). De verschillen tussen grondsoorten waren ook significant: op zand zagen we de meeste soorten (6,1-8,6 soorten), gevolgd door veen (5,2-6,3 soorten) en klei (5,3-5,9 soorten). Overigens was de gemiddelde leeftijd van de gemiddeld-graspercelen 10 jaar en de gemiddelde leeftijd van de divers-graspercelen 21 jaar. Voor het aantal soorten grassen (gemiddeld 3,5-4,5) vonden we geen verschillen tussen grondsoorten en perceelstypen. Het aantal soorten kruiden was het hoogst op zand (2,3-3,6 soorten), lager op veen (1,3-1,8 soorten) en het laagst op klei ( $0,8-1,4$ soorten). 

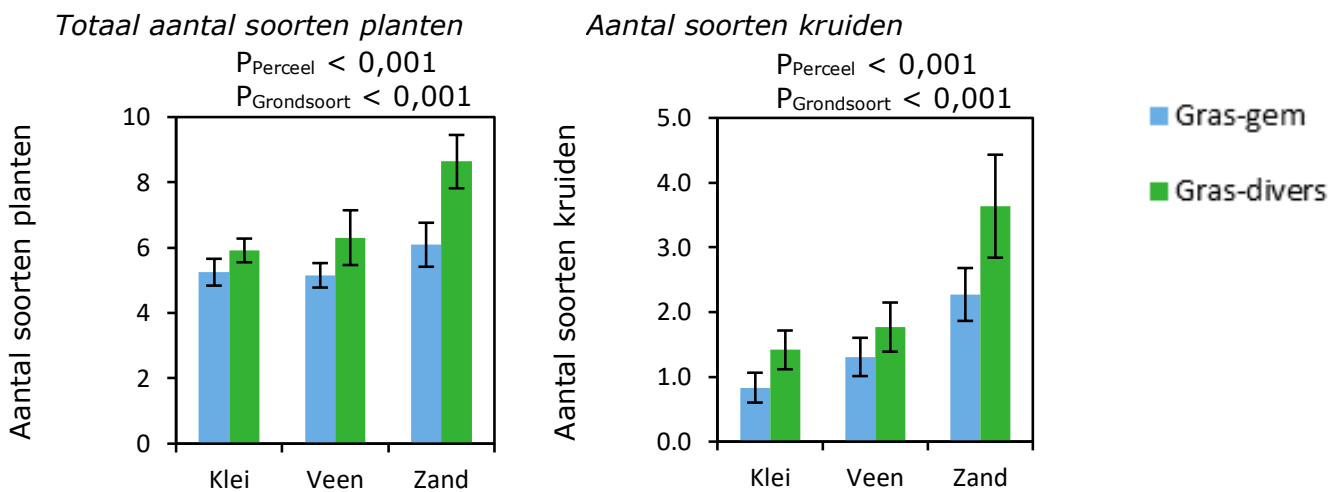

Figuur 5 Het effect van perceelstype en grondsoort op het totaal aantal soorten planten en op het aantal soorten kruiden

\subsubsection{Verbanden met KPI's}

In Tabel 5 staan de relaties tussen de KPI's en de plantenindicatoren op basis van de regressie- en correlatieanalyses (voor details zie Bijlage 3,4 en 5). Er was een positief verband tussen graslandleeftijd en totaal aantal plantensoorten en aantal kruidensoorten. Het stikstofbodemoverschot liet geen (Totaal aantal plantensoorten en Aantal grassoorten) of een tegengesteld (Aantal kruidensoorten negatief voor klei en zand, en positief voor veen) verband zien met de plantenindicatoren. Meetmelk per hectare liet alleen op veen een positief verband zien met het aantal kruidensoorten. Grasopbrengst per hectare liet alleen op veen een negatief verband zien met het aantal kruidensoorten.

Tabel 5 Samenvatting van de relaties tussen KPI's en biodiversiteit uitgedrukt in plantensoorten

\begin{tabular}{|c|c|c|c|}
\hline KPI & Totaal aantal plantensoorten & Aantal grassoorten & Aantal kruidensoorten \\
\hline $\begin{array}{l}\text { 1. Grasland in \% van totale } \\
\text { bedrijfsoppervlakte }\end{array}$ & n.v.t.* & n.v.t. $*$ & n.v.t. $*$ \\
\hline \multicolumn{4}{|l|}{ 2. Blijvend grasland in $\%$ van totale } \\
\hline bedrijfsoppervlakte: & + zand & 0 & + zand \\
\hline \multicolumn{4}{|l|}{ Leeftijd grasland } \\
\hline \multicolumn{4}{|l|}{ van oppervlakte voedergewas } \\
\hline 4. Stikstofbodemoverschot per ha & 0 & 0 & - klei en zand \\
\hline & & & + veen \\
\hline 5. $\mathrm{NH}_{3}$-emissie/ha & n.v.t.* & n.v.t.* & n.v.t.* \\
\hline \multicolumn{4}{|l|}{$\begin{array}{l}\text { 6. Voereiwit geproduceerd op het } \\
\text { eigen bedrijf als } \% \text { totaal voer }\end{array}$} \\
\hline
\end{tabular}




\subsection{Insecten}

\subsubsection{Effect van grondsoort en perceelstype}

De detailinformatie met betrekking tot de insecten staat in Bijlage 3 (Tabel 11). De resultaten staan geïllustreerd in Figuur 6. Bij gebruik van de zuigmethode zagen we geen verschillen in aantallen insecten tussen grondsoort, maar wel tussen perceelstypen: in divers-graspercelen zagen we meer insecten $(6,0-8,2)$ dan in de gemiddeld-graspercelen $(4,5-6,6)$. Voor wat betreft het aantal soorten insecten, troffen we bij gebruik van de zuigmethode gemiddeld 1,9-2,9 soorten aan en waren er geen significante verschillen tussen grondsoorten of perceelstypen.

Bij gebruik van de plakvalmethode zagen we geen verschillen in aantal insecten tussen de grondsoorten, maar wel tussen de perceelstypen: meer insecten in divers-graspercelen (819-1008) dan in gemiddeldgraspercelen (829-900). Het aantal insecten van 4-10 mm groot, verschilde significant tussen de verschillende grondsoorten: de meeste insecten van 4-10 mm werden gevangen op veen.

Aantal insecten zuigmethode

Perceel $<0,05$

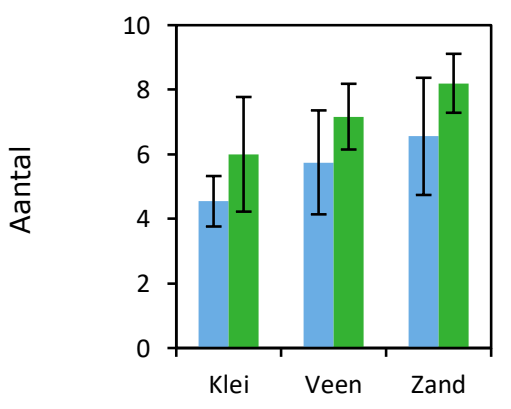

Aantal insecten plakvallen (noorden zuidzijde opgeteld)

$$
\text { Perceel }<0,05
$$

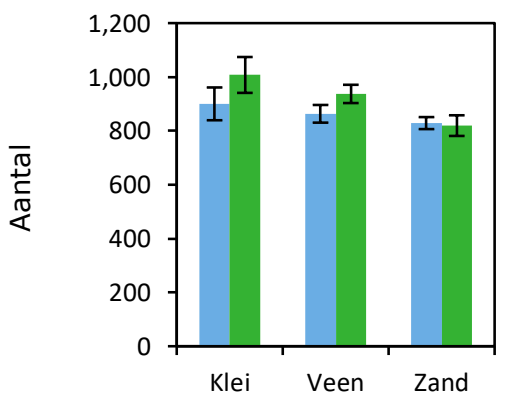

Aantal soorten insecten zuigmethode

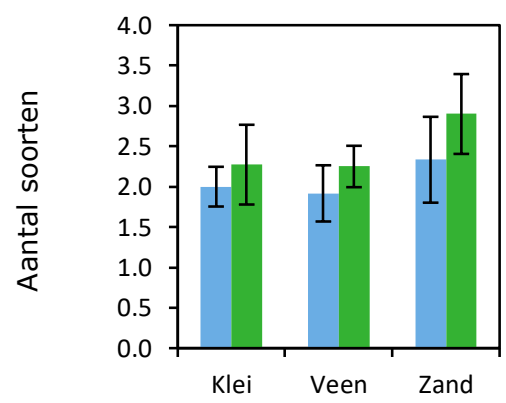

Aantal insecten 4-10mm plakvallen

(noord- en zuidzijde opgeteld)

PGrondsoort $<0,05$

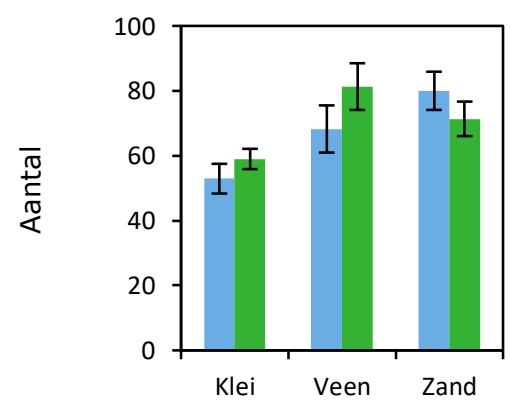

nras-gem

Gras-divers

Figuur 6 Het effect van perceelstype en grondsoort op het aantal insecten en het aantal soorten insecten

\subsubsection{Verbanden met KPI's}

InTabel 6 staan de relaties tussen de KPI's en de insectenindicatoren op basis van de regressie- en correlatieanalyses (voor details zie Bijlagen 3, 4 en 5). De verbanden tussen graslandleeftijd en de insectenindicatoren waren inconsistent. De verbanden tussen het stikstofbodemoverschot en de insectenindicatoren waren ook inconsistent. De verbanden tussen meetmelk per hectare en de insectenindicatoren waren inconsistent. Grasopbrengst per hectare liet geen of een negatief verband zien met een enkele insectenindicator. We hebben gekeken naar of een verband gelegd kon worden tussen aantal typen natuur in de omgeving van het bedrijf en de insectenindicatoren, maar hier zagen we geen consistent verband. 


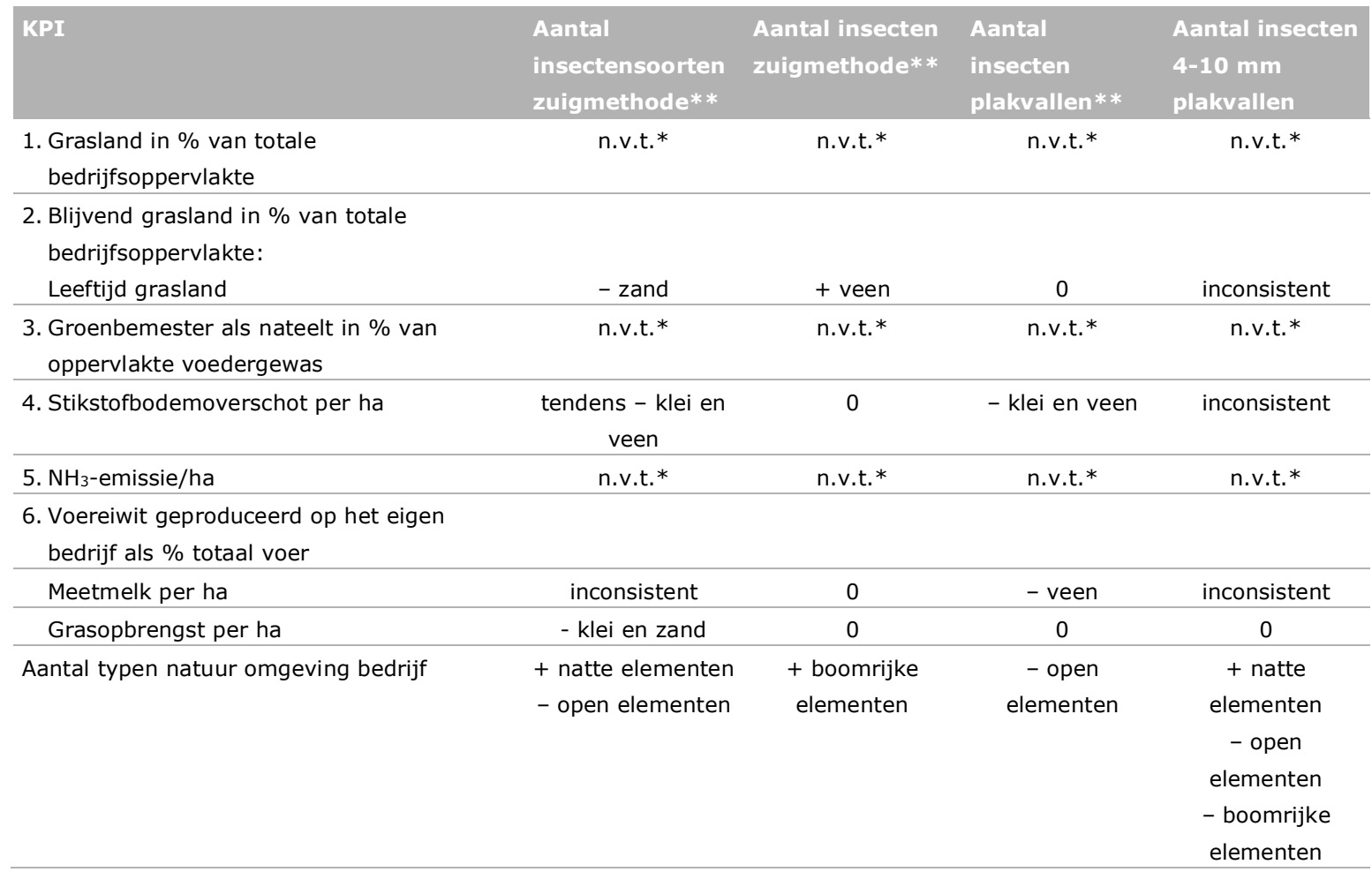

* niet van toepassing: bij de correlatie- en regressieanalyse is alleen gekeken naar verbanden met de KPI's of afgeleide KPI's op de relevante schaal van de indicatoren, in dit geval perceelsniveau (zie ook Tabel 1).

$+\mathrm{Er}$ is positief verband; - $\mathrm{Er}$ is negatief verband; $\mathrm{O} \mathrm{Er}$ is geen verband.

\subsection{Vogels}

\subsubsection{Effect van grondsoort}

In Bijlage 2 (Tabel 13) staan de resultaten van de vogels samengevat in relatie tot grondsoort. In Figuur 7 worden de resultaten geïllustreerd. Het aantal soorten insecteneters (zwaluw, mus en gele kwikstaart) verschilt niet significant tussen de grondsoorten (1,9-2,2 soorten). Er is wel een significant verschil in het aantal soorten wormeneters (spreeuw, scholekster, kievit, grutto, tureluur en wulp): 3,8 soorten op veen, 3,5 op klei en 3,3 op zand. Het aantal soorten roofvogels (torenvalk, kiekendief, kerkuil, steenuil en ransuil) $(1,1-1,7)$ verschilt niet tussen de grondsoorten. Als we alle vogelsoorten bij elkaar optellen, is er ook geen verschil tussen de grondsoorten.
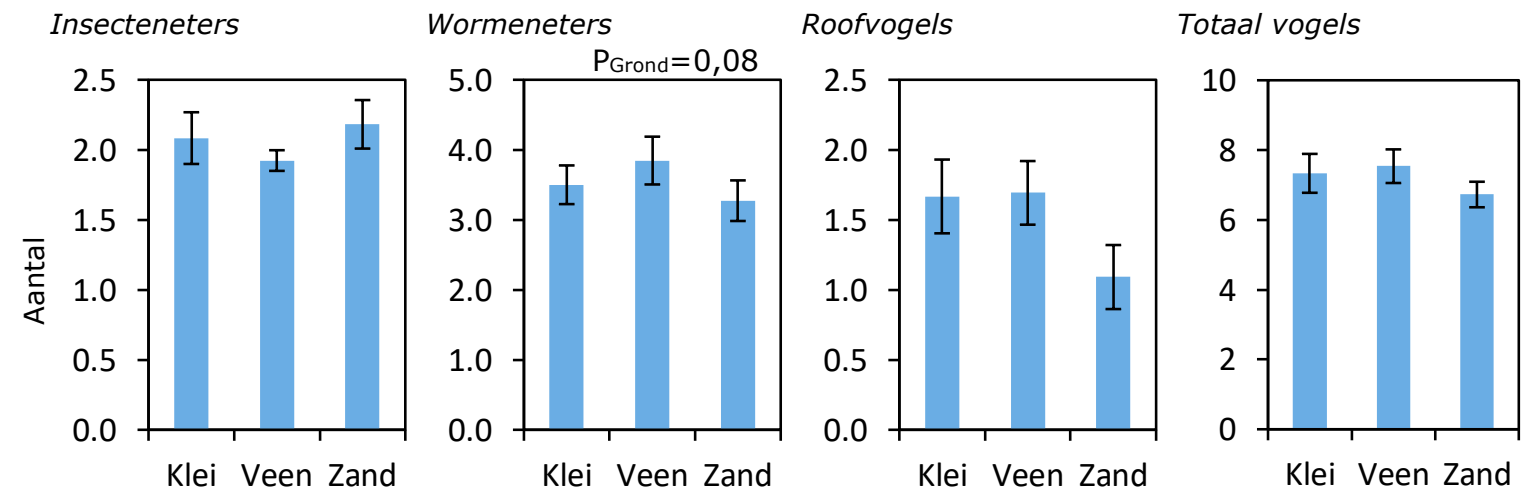

Figur 7 Gemiddeld aantal soorten vogels per bedrijf op klei, veen en zandgrond 


\subsubsection{Verbanden met KPI's}

In Tabel 7 staan de relaties tussen de KPI's en de verschillende vogelsoorten op basis van de correlaties en de regressieanalyses (zie Bijlage 3-5 voor meer details). Het grasland in \% van totale bedrijfsoppervlakte liet per categorie vogels een ander verband zien: negatief met het aantal soorten insecteneters en positief met het aantal soorten wormeneters en het aantal soorten roofvogels op veen. Het percentage blijvend grasland liet met het aantal soorten wormeneters een positief verband zien, maar geen of een negatief verband met de andere vogelindicatoren. Het stikstofbodemoverschot liet een positief verband zien met het aantal soorten wormeneters. Meetmelk per hectare liet geen verband zien met vogelindicatoren. De grasopbrengst per hectare liet een positief verband zien met het aantal soorten wormeneters en een negatief verband met het aantal soorten roofvogels. Met betrekking tot het aantal typen natuur in de omgeving van het bedrijf vonden we alleen voor het aantal soorten wormeneters een negatief verband met boomrijke elementen.

Tabel 7 Samenvatting van de relaties tussen KPI's en biodiversiteit uitgedrukt in vogelindicatoren

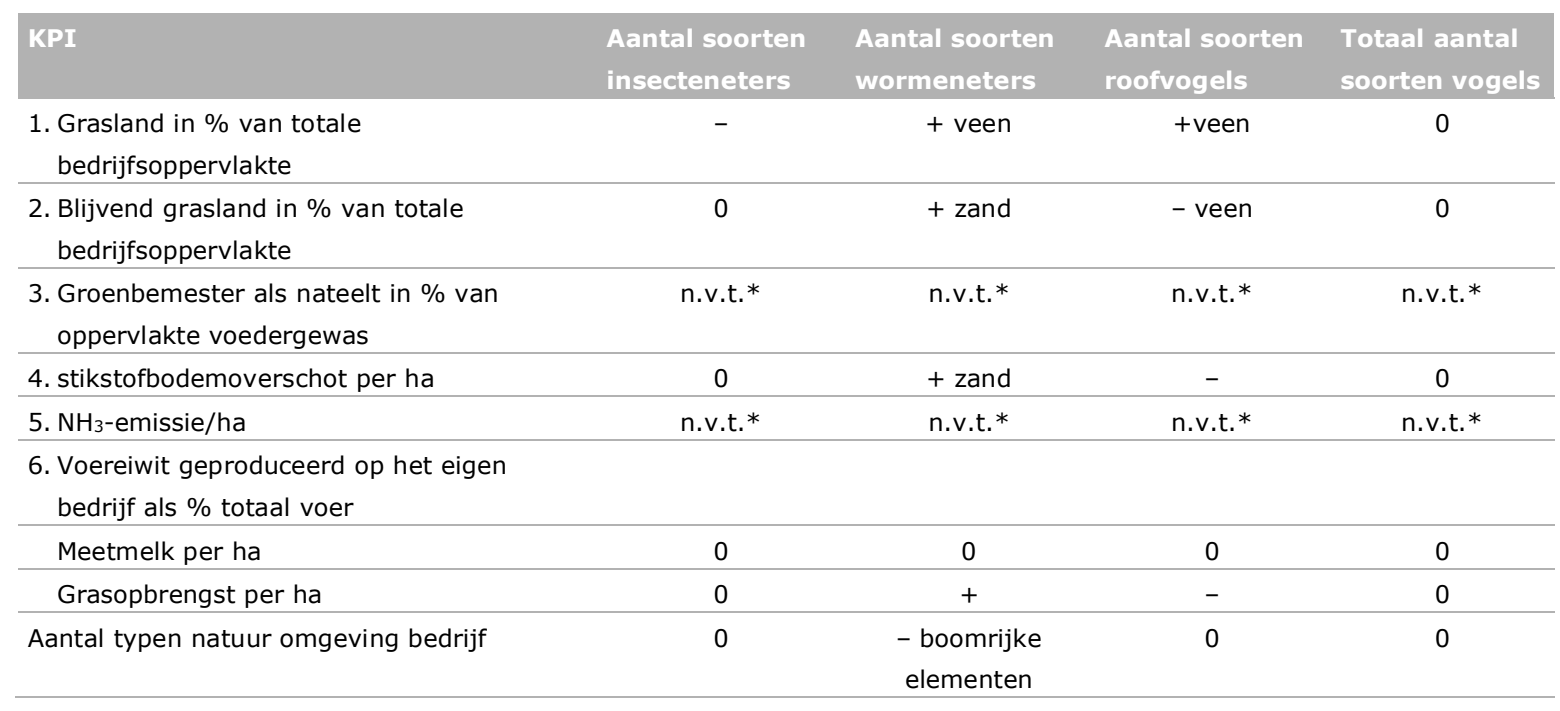

* niet van toepassing: bij de correlatie- en regressieanalyse is alleen gekeken naar verbanden met de KPI's of afgeleide KPI's op de relevante schaal van de indicatoren, in dit geval bedrijfsniveau (zie ook Tabel 1).

$+\mathrm{Er}$ is positief verband; - $\mathrm{Er}$ is negatief verband; $0 \mathrm{Er}$ is geen verband. 


\subsection{Zoogdieren}

\subsubsection{Effect van grondsoort}

In Figuur 8 en in Bijlage 2 (Tabel 13) staat de informatie van de aantallen hazen en reeën in relatie tot grondsoort. Gemiddeld werden 6,4-9,6 hazen gezien en 4,2-8,4 reeën. Er waren geen verschillen tussen de grondsoorten.
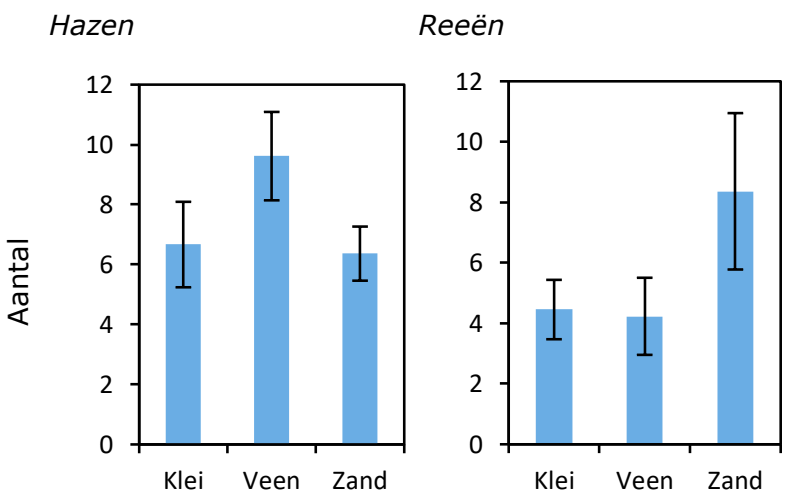

Figuur $8 \quad$ Gemiddeld aantal hazen en reeën per bedrijf en per grondsoort

\subsubsection{Verbanden met KPI's}

In Tabel 8 staan de relaties tussen de KPI's en de zoogdieren op basis van de correlaties en regressieanalyses (voor details zie Bijlage 3-5). Hoewel er geen significante verschillen zijn tussen de grondsoorten (zie 3.7.1), laten de regressieanalyses soms wel een verband zien. Het is eigenlijk niet mogelijk om iets zinnigs te zeggen over hoe de KPI's zich verhouden tot de aantallen hazen en reeën.

\section{Tabel 8 Samenvatting van de relaties tussen KPI's en biodiversiteit uitgedrukt in zoogdieren}

\begin{tabular}{|c|c|c|}
\hline KPI & Hazen & Reeën \\
\hline 2. Blijvend grasland in $\%$ van totale bedrijfsoppervlakte & + op zand & - veen \\
\hline $\begin{array}{l}\text { 3. Groenbemester als nateelt in \% van oppervlakte } \\
\text { voedergewas }\end{array}$ & n.v.t.* & n.v.t.* \\
\hline 4. Stikstofbodemoverschot per ha & $+($ veen $) /-($ zand $)$ & - \\
\hline \multicolumn{3}{|l|}{$\begin{array}{l}\text { 6. Voereiwit geproduceerd op het eigen bedrijf als \% } \\
\text { totaal voer }\end{array}$} \\
\hline Meetmelk per ha & 0 & inconsistent \\
\hline Grasopbrengst per ha & $+($ veen $)$ & - (veen) \\
\hline
\end{tabular}

* niet van toepassing: bij de correlatie- en regressieanalyse is alleen gekeken naar verbanden met de KPI's of afgeleide KPI's op de relevante schaal van de indicatoren, in dit geval bedrijfsniveau (zie ook Tabel 1).

$+\mathrm{Er}$ is positief verband; - Er is negatief verband; $0 \mathrm{Er}$ is geen verband; inconsistent: zowel negatieve als positieve verbanden. 


\subsection{Synthese}

In de paragrafen 3.1 tot en met 3.7 keken we per categorie bij elkaar horende biodiversiteitsindicatoren tot in detail naar mogelijke verbanden. In deze paragraaf (Tabel 9) zoomen we uit en proberen we per KPI te kijken hoe deze zich verhoudt tot de overkoepelende biodiversiteitscategorieën.

Op perceelsniveau had het grasland in \% van totale bedrijfsoppervlakte (of: gras in vergelijking met bouwland) een positief verband met meerdere biodiversiteitscategorieën. Op bedrijfsniveau echter, was het verband met grasland in \% van totale bedrijfsoppervlakte (soorten vogels en aantal zoogdieren) sterk wisselend of inconsistent.

Graslandleeftijd had op perceelsniveau een positief verband met meerdere biodiversiteitscategorieën. Het aandeel blijvend grasland had een wisselend effect op vogels en zoogdieren op bedrijfsniveau.

Voor groenbemester als nateelt in \% van oppervlakte voedergewas hebben we geen verbanden kunnen vaststellen.

Het stikstofbodemoverschot liet een sterk wisselend verband zien met de verschillende biodiversiteitscategorieën.

Meetmelk per hectare vertoonde nauwelijks verbanden met de biodiversiteitscategorieën.

Grasopbrengst per hectare vertoonde ook sterk wisselende verbanden met biodiversiteitscategorieën, variërend van sterk positief met bodemgezondheid en wormen tot neutraal voor planten en insecten en sterk wisselend op bedrijfsniveau.

De resultaten laten ook een duidelijke invloed zien van grondsoort en van het aantal typen natuur in de omgeving van het bedrijf: deze effecten kunnen zowel negatief als positief zijn, afhankelijk van de biodiversiteitsindicator. Divers grasland had in vergelijking met gemiddeld grasland op perceelsniveau met meerdere biodiversiteitscategorieën een positief verband.

Tabel 9 Samenvatting van de relaties tussen KPI's en gemeten biodiversiteit

\begin{tabular}{|c|c|c|c|c|c|c|}
\hline \multirow[b]{2}{*}{ KPI } & \multicolumn{4}{|c|}{ Perceelsniveau } & \multicolumn{2}{|c|}{ Bedrijfsniveau } \\
\hline & Bodem & Wormen & Planten & Insecten & Vogels & Zoogdieren \\
\hline $\begin{array}{l}\text { 1. Grasland in \% van totale } \\
\text { bedrijfsoppervlakte }\end{array}$ & n.v.t. & n.v.t. & n.v.t. & n.v.t. & wisselend & inconsistent \\
\hline Perceel (gras vs bouw) & + & & & & & \\
\hline $\begin{array}{l}\text { 2. Blijvend grasland in \% van totale } \\
\text { bedrijfsoppervlakte }\end{array}$ & n.v.t. & n.v.t. & n.v.t. & n.v.t. & wisselend & wisselend \\
\hline Graslandleeftijd & meestal + & meestal + & meestal + & inconsistent & n.v.t. & n.v.t. \\
\hline $\begin{array}{l}\text { 3. Groenbemester als nateelt in \% van } \\
\text { oppervlakte voedergewas }\end{array}$ & n.v.t. & n.v.t. & n.v.t. & n.v.t. & n.v.t. & n.v.t. \\
\hline 4. Bodemoverschot stikstof & meestal + & $\begin{array}{l}\text { gewicht per worm + } \\
\text { overige } 0 /-\end{array}$ & $\begin{array}{c}\text { meestal } 0 \\
/-\end{array}$ & inconsistent & wisselend & wisselend \\
\hline 5. $\mathrm{NH}_{3}$-emissie/ha & n.v.t. & n.v.t. & n.v.t. & n.v.t. & n.v.t. & n.v.t. \\
\hline \multicolumn{7}{|l|}{$\begin{array}{l}\text { 6. Voereiwit geproduceerd op het eigen } \\
\text { bedrijf als \% totaal voer }\end{array}$} \\
\hline Meetmelk per ha & 0 & $+1-$ & Meestal 0 & inconsistent & 0 & 0 \\
\hline Grasopbrengst per ha & meestal + & meestal + & meestal 0 & meestal 0 & wisselend & wisselend \\
\hline Grondsoort & $V \geq K>Z$ & wisselend & $\mathrm{Z}>\mathrm{V} \geq \mathrm{K}$ & wisselend & wisselend & wisselend \\
\hline $\begin{array}{l}\text { Divers grasland (ipv gemiddeld } \\
\text { grasland) }\end{array}$ & tendens + & tendens + & + & tendens + & n.v.t. & n.v.t. \\
\hline Aantal typen natuur omgeving bedrijf & n.v.t. & n.v.t. & n.v.t. & $\begin{array}{l}\text { + nat } \\
\text { - open }\end{array}$ & wisselend & wisselend \\
\hline
\end{tabular}

${ }^{*}$ Niet gemeten Inconsistent: resultaten van correlatie- en regressieanalyses laten tegenstrijdige verbanden zien.

Wisselend: verband met KPI is anders voor verschillende indicatoren binnen een categorie (bodem, wormen, enzovoort).

Grondsoort: V=veen; K=klei; $Z=$ zand. 


\section{Discussie}

\subsection{Steekproefgrootte}

De steekproef bestond uit 36 melkveebedrijven. Deze zijn geselecteerd uit 197 bedrijven die verdeeld zijn over 3 grondsoorten, 3 intensiteitsklassen en 4 klassen voor biodiversiteit. Binnen deze groepen zijn de bedrijven random geselecteerd. Met name grondsoort bleek bepalend te zijn voor een aanzienlijk deel van de verschillen in biodiversiteit. Dit werd vooraf weliswaar reeds verwacht en om meer inzicht te krijgen in de verschillen tussen grondsoorten is daarom bewust gekozen voor onderzoek op 3 grondsoorten. Immers, de biodiversiteitsmonitor wordt ontwikkeld voor melkveebedrijven op alle grondsoorten. Bij een grotere steekproef zouden we meer, sterker significante en wellicht ook eenduidiger verbanden tussen KPI's en gemeten biodiversiteit kunnen verwachten. Een grotere steekproef was echter binnen de financiële kaders van deze studie niet mogelijk. Ook maakten we binnen het onderzoek gebruik van de menselijke maat door de melkveehouder vragen te stellen over vogels en andere fauna. Binnen de financiële kaders van deze studie was dit niet op een andere manier in te vullen, maar dit heeft mogelijk wel consequenties gehad voor de resultaten.

\subsection{Evaluatie biodiversiteitsindicatoren}

In deze paragraaf beschrijven we in hoeverre we, op basis van onze ervaringen en resultaten, de gebruikte biodiversiteitindicatoren geschikt vinden voor de beoordeling van de KPI's. Daarnaast duiden we aan in hoeverre de biodiversiteitsindicatoren in de toekomst bruikbaar zouden zijn om biodiversiteit te meten op grote aantallen melkveebedrijven.

\subsubsection{Bodemindicatoren}

De analyses door Cornell University (Soil Health Index) staan goed aangeschreven en leveren nauwkeurige getallen op, maar streefwaarden zijn gebaseerd op de omstandigheden in de VS. De indicatoren zijn met enige uitleg geschikt om het belang van werken aan een goede bodemgezondheid te ondersteunen. De monsters zijn niet heel moeilijk te nemen, maar het feit dat ze naar de Verenigde Staten opgestuurd moeten worden en persoonlijk contact over de bevindingen niet mogelijk is, maakt deze wijze van meten van biodiversiteit nogal bewerkelijk en vergt het veel tijd. Voor de analyses door Eurofins geldt dat de werkwijze bekend is en de bepalingen snel en volgens in Nederland bekende protocollen worden uitgevoerd. Deze soort van biodiversiteit is dus goed te meten en is een zinvol onderdeel van onderzoek naar biodiversiteit op melkveebedrijven.

\subsubsection{Wormen}

Regenwormen zijn algemeen erkend als indicator voor bodembiodiversiteit. Het feit dat iedereen ze herkent en dat ze bij wijze van spreken met een beetje moeite overal zichtbaar zijn, helpt in de communicatie over biodiversiteit. Aantallen en gewicht per $\mathrm{m}^{2}$ geven informatie over hun rol als voedselbron voor bijvoorbeeld weidevogels, waarbij ook de soort worm belangrijk is. Het gewicht per worm geeft een indruk van de geschiktheid als voedsel; voor weidevogels zijn grote wormen meer geschikt als voedsel dan kleine wormen. Het aantal soorten wormen weerspiegelt de biodiversiteit. Het verzamelen van regenwormen voor onderzoek is echter alleen zinvol in het juiste seizoen. Het beste tijdstip om regenwormen te onderzoeken (najaar en vroege voorjaar) valt niet samen met het onderzoeken van andere vormen van bovengrondse biodiversiteit. Verzamelen en verwerken van de monsters (plaggen steken en de wormen daar handmatig uit peuteren) is zeer bewerkelijk. Determineren op soortniveau is specialistisch werk. Naast seizoen kunnen ook weersinvloeden (regenval, droogte, temperatuur) en gevolgen daarvan (grondwaterstand) een rol spelen. Een 
afgeleide van droogte van de bodem (\% droge stof) kan redelijk makkelijk meegenomen worden wanneer ook grondanalyses gedaan worden. Die kunnen dan corrigeren voor bemonsteringstijdstip (hoe droger de gronden, des te minder wormen), maar ook als maat dienen voor de beschikbaarheid voor wormen voor de weidevogels. Immers, hoe droger de grond, des te hoger de indringingsweerstand en hoe moeilijker de vogel met zijn snavel in de grond kan. Voor onderzoek naar biodiversiteit op een groot aantal bedrijven is onderzoek naar wormen als indicator voor biodiversiteit minder geschikt.

\subsubsection{Planten}

Diversiteit aan planten is algemeen erkend als indicator voor biodiversiteit. Het gemak waarmee afzonderlijke soorten daadwerkelijk te vinden zijn, hangt af van het seizoen (bloeiwijze maakt ze herkenbaar) en wanneer voor het laatst gemaaid of geweid is. Herkennen van de soorten is redelijk specialistisch werk, vooral als het om grassoorten gaat. Vanaf wanneer is sprake van biodiversiteit: vanaf een minimaal aantal soorten grassen of kruiden? Of bij aanwezigheid van specifieke soorten? Overigens zijn sommige soorten gewoon in te zaaien. Dus in hoeverre is de gevonden biodiversiteit dan de kroon op het werk van de veehouder als natuurbeheerder of gewoon een maatregel? We hebben opzettelijk gemeten aan diversiteit in productiepercelen: die zijn op elk bedrijf aanwezig. Ook de divers-graspercelen waren 'gewone' productiepercelen. Onze indeling staat dus los van eventuele definities van kruidenrijk grasland, zoals gehanteerd ten behoeve van beheerspakketten. Onze indeling staat ook los van eventuele functies van kruidenrijk grasland, namelijk biodiversiteit in de vorm van meer soorten planten, of als randvoorwaarde voor meer soorten insecten die voedsel kunnen zijn voor vogels. De diversiteit van planten is daarentegen beperkt geschikt als indicator voor biodiversiteit op bedrijfsniveau. Tenslotte waren de gemiddeld-graspercelen gemiddeld 10 jaar en de divers-graspercelen gemiddeld 21 jaar oud. Graslandleeftijd heeft een rol gespeeld in de gevonden verschillen tussen de percelen en is wat dat betreft een belangrijke indicator voor biodiversiteit. De exacte leeftijd van de oudere percelen is echter niet bekend, de geïnterviewde ondernemers konden vaak hooguit een schatting geven in de trant van 'na de oorlog' of '40 tot 50 jaar geleden was het ook al gras'. Wellicht kan een indeling in leeftijdscategorieën hier uitkomst bieden, waarbij de oudste categorie bijvoorbeeld 'ouder dan 40 jaar' is.

\subsubsection{Insecten}

Diversiteit aan insecten is algemeen erkend als indicator voor biodiversiteit. Het gemak waarmee ze te vinden zijn, hangt af van of ze er überhaupt zijn, van de grashoogte (recent gemaaid of beweid), het aantal soorten planten en ook de aanwezigheid van specifieke plantensoorten. Insecten zijn als zodanig biodiversiteit, maar ze zijn ook randvoorwaarde voor andere vormen van biodiversiteit, doordat ze als voedsel dienen. We hebben twee meetmethodes gebruikt. De zuigmethode met een omgebouwde bladblazer, waarmee overdag insecten gevangen worden, is waarschijnlijk meer geschikt voor gebruik in langere vegetatie. De gewashoogte op productiegraspercelen is mogelijk al snel te laag voor deze methode. De soorten insecten die met deze methode gevangen worden, zijn mogelijk vooral de categorieën die als voedsel kunnen dienen. Met de tweede vangmethode, de plakvalmethode, werden veel meer insecten en veel meer soorten gevangen. Bovendien werden de insecten over een langere periode gevangen ( 2 etmalen) en was er geen verstoring. De resultaten van de plakvalmethode zijn echter sterk weersafhankelijk, moeten op verschillende locaties tegelijkertijd plaatsvinden en vergen daardoor een uitgekiende logistiek. Plaatsen en ophalen van de plakvallen is arbeidsintensief. De vallen kunnen automatisch geteld worden en dat geeft, als het om aantallen insecten in bepaalde groottecategorieën gaat, nauwkeurige resultaten. Visueel beoordelen door een deskundige, waarbij hij ook soort(groep)en kan meenemen, vergt vakkennis en is arbeidsintensief. De plakvalmethode is dus bewerkelijk, maar helpt wel om biodiversiteit zichtbaar te maken. Op basis van onze ervaringen met beide methoden kunnen we zeggen dat afhankelijk van het doel (insecten als biodiversiteit, insecten als voedsel), de ene of de andere methode meer geschikt is. Voor een snelle indicatie van biodiversiteit op een groot aantal bedrijven zijn beide methoden echter minder geschikt. 


\subsubsection{Vogels}

De aanwezigheid van bepaalde categorieën vogels (bijvoorbeeld weidevogels, zwaluwen, ooievaars) erkennen we algemeen als biodiversiteit. Andere categorieën (bijvoorbeeld ganzen, spreeuwen in de stal) zien veehouders eerder als een plaag. Betekenisvolle metingen doen aan vogels is vrij specialistisch werk, arbeidsintensief en moet bij voorkeur op specifieke momenten in het juiste seizoen gedaan worden. Ook is de aanwezigheid van bepaalde soorten op een bedrijf slechts ten dele gerelateerd aan de inspanningen van het bedrijf zelf. Tenslotte zullen in open gebieden weidevogels meer te verwachten zijn dan in landschappen met houtwallen en andere vormen van begroeiing. Dit laatste bleek ook uit onze resultaten. Niet alle melkveehouders zijn 'af te rekenen' op de aanwezigheid van bijvoorbeeld grutto's. Dit alles maakt echter dat vogels weliswaar een aansprekende categorie biodiversiteit vormen, maar dat het in het kader van een snel onderzoek een lastige categorie is om op zinvolle wijze mee te nemen. Verzamelen van vogeldata door de melkveehouder te vragen naar de aanwezigheid van soorten en de wijze waarop wij die ingedeeld hebben, kunnen we zonder nader onderzoek naar mogelijke verbeteringen niet aanbevelen.

\subsubsection{Zoogdieren}

Voor zoogdieren geldt net als bij vogels dat we de aanwezigheid van bepaalde categorieën beschouwen als biodiversiteit (bijvoorbeeld das), terwijl we andere soorten (muizen en ratten) of soms zelfs dezelfde soorten (hazen), als ongewenst of schadelijk beschouwen. Net als bij vogels geldt dat betekenisvolle metingen doen vrij specialistisch en arbeidsintensief is en op het juiste moment moet gebeuren. Ook geldt dat sommige diersoorten meer voorkomen in open gebieden (hazen) en andere meer in gebieden met landschapselementen of zelfs bossen (reeën, dassen). Verzamelen van zoogdierdata door de melkveehouder te vragen naar de aanwezigheid van soorten geeft slechts een zeer ruwe indicatie van deze vorm van biodiversiteit.

\subsection{Relatie tussen KPI's en biodiversiteit}

Een aanname bij het relateren van KPI's aan biodiversiteit, is dat het effect van een KPI op de gemeten biodiversiteit zichtbaar of meetbaar is. Echter, sommige effecten hebben tijd nodig. Bodembiologie en organischestofgehalte bijvoorbeeld, worden niet zozeer bepaald door de huidige score op de KPI's, maar vooral door hoe de score was in de afgelopen jaren. Een bedrijf kan heel hoog scoren op kruidenrijk grasland, maar als dat grasland pas net is omgezet, vind je nog weinig ecologisch effect in de bodem. In zo'n geval zegt de huidige KPI weinig over het niveau van de biodiversiteit en kan het zelfs een verkeerd beeld schetsen.

Zoals gesteld in de hypotheses (Tabel 1 ) zijn niet alle KPI's toepasbaar als indicator voor biodiversiteit op individuele melkveebedrijven. Het stikstofbodemoverschot heeft bijvoorbeeld gevolgen voor de biodiversiteit op regionaal niveau, maar niet direct of slechts zeer beperkt op de percelen van het bedrijf waar het wordt geproduceerd. In de volgende paragraaf gaan we hier nader op in voor de KPI's die - direct of indirect - zijn beoogd voor gebruik binnen de biodiversiteitsmonitor.

\subsubsection{Percentage grasland en perceelstype}

\section{Perceelsniveau}

Op perceelsniveau wordt het grasland in \% van totale bedrijfsoppervlakte weergegeven door het verschil tussen bouwland en grasland. Zoals verwacht was de bodembiodiversiteit (Soil Health Index, bodemleven) hoger op grasland dan op bouwland. De overige biodiversiteitscategorieën op perceelsniveau (wormen en planten) hebben we niet gemeten op bouwland. Uit eerder onderzoek bleek wel een positief effect van grasland in vergelijking met bouwland (Van Eekeren et al., 2008).

\section{Bedrijfsniveau}

Op bedrijfsniveau was het verband tussen grasland in \% van totale bedrijfsoppervlakte en de afzonderlijke biodiversiteitsindicatoren sterk wisselend. Er was een negatief verband met het aantal soorten insecten etende vogels en op veen was er een positief verband met het aantal soorten 
wormeneters en roofvogels. Het negatieve verband tussen grasland in \% van totale bedrijfsoppervlakte en de categorie insecteneters wordt mogelijk verklaard door de diversiteit binnen de categorie insecteneters. De gele kwikstaart broedt bijvoorbeeld vaak op bouwland en een hoger percentage grasland in \% van totale bedrijfsoppervlakte gaat gepaard met een lager \% bouwland. Huismussen zijn voor broedgelegenheid en voedsel sterk verbonden aan bebouwing en groen op en rond het erf. Hier verwachten we dus geen positieve relatie met grasland in \% van totale bedrijfsoppervlakte. Hoewel zwaluwen en gele kwikstaart hun voedsel wel boven grasland zoeken, is de kwaliteit van het grasland voor hen wellicht belangrijker dan de kwantiteit. De kwaliteit wordt bepaald door beweiding (aanwezigheid van mestflatten) en maaifrequentie (grashoogte). Voor wormeneters is weide aantrekkelijk in verband met de grote voedselbeschikbaarheid (meer wormen onder grasland in vergelijking tot bouwland), mogelijk in combinatie met een meer open landschap. $\mathrm{Er}$ waren geen consistente verbanden met het aantal reeën en hazen. Mogelijk worden deze soorten meer beïnvloed door de omgeving en grondsoort dan door het specifieke beheer op het bedrijf zelf.

\subsubsection{Percentage blijvend grasland en leeftijd van grasland}

\section{Perceelsniveau}

Over het algemeen was er een positief verband tussen de graslandleeftijd en bodembiodiversiteit. Deze effecten waren het sterkst op zand en klei. Het is algemeen bekend dat het organischestofgehalte en daarmee samenhangend de waterbergingscapaciteit, aggregaatstabiliteit en bodemleven toenemen bij hogere graslandleeftijd (Van Eekeren et al., 2008; Iepema et al., in voorbereiding). Er was een positief verband tussen graslandleeftijd en de wormenindicatoren (aantal, aantal soorten en gewicht per worm). Ook dit komt overeen met verwachtingen. Met name op zand was er een positief verband tussen de graslandleeftijd en het totaal aantal plantensoorten en het aantal kruidensoorten. Op ouder grasland is de botanische samenstelling over het algemeen het meest divers. Dit geldt vooral op zandgrond, waar het snelst droogte optreedt, waardoor andere dan productiesoorten een kans krijgen. Op klei daarentegen, verandert de botanische samenstelling vaak langzaam doordat Engels raaigras hier het best floreert en de soortensamenstelling domineert. Met betrekking tot insectenindicatoren was het verband met graslandleeftijd zeer wisselend, zowel per grondsoort als per methode en komt er geen duidelijke lijn naar voren. Wellicht waren andere factoren van grotere betekenis, bijvoorbeeld de lengte van het gras. Met de zuigmethode werden in hoger gras meer insecten gevangen dan in recent gemaaid gras. Daarnaast is bij de plakvallen alleen gekeken naar het aantal insecten (binnen grootteklassen), maar niet naar verschillende soorten. Verdere identificatie van de soorten levert mogelijk nog andere inzichten op.

\section{Bedrijfsniveau}

Voor vogels zagen we positieve en negatieve verbanden bij een hoger aandeel blijvend grasland; er waren met name op zand meer wormeneters bij een hoger aandeel blijvend grasland. Dit is mogelijk gerelateerd aan de grotere beschikbaarheid van voedsel (wormen) op ouder grasland.

De verbanden met het aantal hazen en reeën waren zeer wisselend en moeilijk te verklaren.

\subsubsection{Percentage toepassing groenbemester}

Deze KPI hebben we in dit onderzoek niet verder uitgewerkt. Gebruik van groenbemester is soms verplicht, bijvoorbeeld op zand. Groenbemester als nateelt in \% van oppervlakte voedergewas bleek sterk verweven met grondsoort (Figuur 1), maar dat zegt dan weinig. Bovendien heeft deze KPI voornamelijk betrekking op bouwland en daar is alleen bodembiodiversiteit gemeten. Tenslotte was er op een beperkt aantal bedrijven bouwland aanwezig: 8, 5 en 9 bedrijven op respectievelijk klei, veen en zand. Dit alles leidde ertoe dat er geen zinvolle en geen sterke relaties verwacht werden voor deze KPI. In beperkte mate draagt een vanggewas of groenbemester bij aan de organische-stofaanvoer (Van Schooten et al., 2005). Voor specifieke soorten zoals zaden etende vogels is vooral een stoppelgewas interessant. Begroeid bouwland biedt weinig voedselbronnen voor vogels in de winter, doordat de gewasresten ondergewerkt zijn (Holland, 2004). Let wel, grasland heeft de voorkeur boven bouwland voor functionele biodiversiteit op een melkveebedrijf (Reidsma et al., 2006), dus deze KPI valt in rangorde onder de KPI aandeel grasland van het totale areaal. 


\subsubsection{Stikstofbodemoverschot per ha}

\section{Perceelsniveau}

Het stikstofbodemoverschot was over het algemeen positief gerelateerd aan bodembiodiversiteit (Soil Health Index en Eurofins bodemleven). Echter, dit effect was sterk gecorreleerd met grondsoort: over het algemeen was de bodembiodiversiteit het hoogst op veen gevolgd door klei en zand. Hetzelfde patroon is zichtbaar voor stikstofbodemoverschot, welke door de hoge $\mathrm{N}$-levering uit veengrond ook afneemt van veen naar zand (Figuur 1). Binnen de grondsoorten was er nauwelijks een verband met $\mathrm{N}$ bodemoverschot, met uitzondering van zand, waar er wel een positieve tendens was. Er was weinig tot geen effect van $\mathrm{N}$ bodemoverschot op de wormenindicatoren. Alleen het gewicht per worm was hoger bij een hoger stikstofbodemoverschot, terwijl het aantal soorten en de totale wormbiomassa juist een negatieve tendens vertoonden. Op zand en klei was er een negatief verband tussen stikstofstikstofbodemoverschot en het aantal soorten kruiden. Dit is in lijn met verwachtingen, aangezien de concurrentiekracht van met name Engels raaigras toeneemt bij hogere bemestingsniveaus en er dus minder ruimte is voor de ontwikkeling van kruiden. Er waren nauwelijks significante verbanden tussen stikstofbodemoverschot en de insectenindicatoren.

\section{Bedrijfsniveau}

Het aantal soorten wormen etende vogels was positief gerelateerd aan het $\mathrm{N}$ bodemoverschot, met name op zand. Mogelijk is dit gerelateerd aan de beschikbaarheid van grote wormen. Het aantal soorten roofvogels was juist negatief gerelateerd en er was geen verband met het totaal aantal soorten vogels.

\subsubsection{Ammoniakemissie per hectare}

Het verwachte effect van deze KPI ligt voornamelijk op regionaal of nationaal niveau en niet op perceels- en bedrijfsniveau. Hij wordt daarom hier verder niet uitgewerkt.

\subsubsection{Percentage voereiwit eigen bedrijf}

\section{Perceelsniveau}

We zagen weinig relatie tussen intensiteit (hier gedefinieerd als meetmelk per ha) en biodiversiteit. Er waren geen significante correlaties met bodemindicatoren. Het effect op de wormenindicatoren was zeer wisselend en sterk afhankelijk van grondsoort. Er was een positief verband tussen meetmelk per ha en het aantal wormen, de wormbiomassa op zand en het wormgewicht op veen. Mogelijk hangt dit samen met het gebruik van drijfmest of hogere mestgift. Het aantal wormen reageren over het algemeen positief op een hoge mestgift (Andersen, 1983). Het aantal wormen en de wormenbiomassa per $\mathrm{m}^{2}$ zijn weliswaar belangrijk voor het voedselweb, maar het soort worm is ook belangrijk. Strooiselbewoners zijn voedsel voor weidevogels. Een hogere wormenbiomassa lijkt dus een goede indicatie voor biodiversiteit, maar is dat slechts ten dele. Er was geen consistent verband met het aantal kruidensoorten, hooguit een licht positief effect op veen en ook de insectenindicatoren vertoonden geen consistente verbanden met de meetmelk per ha.

\section{Bedrijfsniveau}

Er was geen verband tussen meetmelk per ha en het aantal vogelsoorten en het aantal zoogdieren.

\subsubsection{Grasopbrengst per ha}

\section{Perceelsniveau}

Grasproductie uitgedrukt in stikstof, was over het algemeen positief gerelateerd aan de bodembiodiversiteit. Het lijkt waarschijnlijk dat de hogere grasproductie $\mathrm{N}$ niet de oorzaak is van de betere bodembiodiversiteit, maar juist andersom. Dus dat de betere bodembiodiversiteit resulteert in een betere grasproductie. Dit positieve verband tussen bodembiodiversiteit en grasopbrengst is in proeven op zand, klei en veen aangetoond (Van Eekeren et al., 2010; Iepema et al., in voorbereiding; Pijlman et al., in voorbereiding). Er was ook een overwegend positief verband tussen grasopbrengst en de wormindicatoren, met name op zand en klei. De bevinding dat bodembiodiversiteit gepaard kan gaan met hogere grasproductie, is iets dat in de communicatie met veehouders gebruikt zou kunnen 
worden; dit aspect zal naar verwachting veel invloed hebben op het draagvlak om te werken aan biodiversiteit op melkveebedrijven. Er was duidelijk verband met het totaal aantal plantensoorten, met uitzondering van het aantal kruiden op veen, dat afnam bij toenemende graslandopbrengst. Over het algemeen is Engels raaigras de meest productieve soort met de hoogste voederwaarde en zou een hogere botanische soortenrijkdom kunnen leiden tot een lagere graslandopbrengst. Echter: zeker bij lagere bemestingsniveaus hoeft de graslandproductie niet erg te lijden en kan hogere soortenrijkdom ook voordelen opleveren. Bijvoorbeeld doordat er soorten tussen zitten met diepere beworteling en een hogere droogteresistentie, of klavers die stikstof binden (De Wit et al., 2013). Het aantal soorten insecten vertoonde een negatief verband met de grasopbrengst op klei en zand, maar er was geen verband met de overige insectenindicatoren.

\section{Bedrijfsniveau}

Er waren zowel positieve als negatieve effecten gezien op aantallen vogelsoorten en aantal hazen en reeën.

\subsubsection{Bruikbaarheid van de KPI's als indicator voor biodiversiteit}

We vonden veel significante relaties tussen de KPI's en de verschillende biodiversiteitsindicatoren. Echter, de interpretatie van deze verbanden behoeft enige nuancering. De analyses laten zien dat de relatie tussen de KPI's en biodiversiteit sterk verweven is met grondsoort. De relaties kunnen zelfs tegengesteld zijn voor de verschillende grondsoorten. Doordat per grondsoort van slechts 11 tot 13 bedrijven gegevens zijn, maakt dit het karakter van de uitkomsten exploratief.

De relaties tussen de KPI's en de verschillende biodiversiteitscategorieën (bijvoorbeeld bodem- en plantensoorten) waren soms ook tegengesteld. Zelfs binnen een biodiversiteitscategorie kon de relatie met KPI's verschillen. Het aantal soorten wormen etende vogels vertoonde bijvoorbeeld vaak een tegengestelde relatie ten opzichte van het aantal soorten insecten etende vogels. Als gevolg daarvan is er geen verband tussen het totaal aantal soorten vogels en de KPI's.

Het bovenstaande bevestigt de noodzaak om doelen op het gebied van biodiversiteit (bijvoorbeeld algemeen aantal soorten vogels of specifiek weidevogels) helder te benoemen, en daarmee de keuze van KPI's die worden opgenomen in de biodiversiteitsmonitor. De doelen moeten aansluiten bij de gewenste biodiversiteitsimpact en daarmee ook bij bijvoorbeeld regiospecifieke natuurdoelen die rekening houden met grondsoorten.

Op basis van het voorgaande in paragraaf 4.3 vatten we onze bevindingen samen in relatie tot de bruikbaarheid van de KPI's als indicator voor biodiversiteit op melkveebedrijven:

- Grasland in \% van totale bedrijfsoppervlakte op bedrijfsniveau en op perceelsniveau is positief gerelateerd aan meerdere (maar niet alle) biodiversiteitscategorieën. Deze KPI is bruikbaar als indicator voor waarneembare biodiversiteit.

- Blijvend grasland in \% van totale bedrijfsoppervlakte is ook positief gerelateerd aan meerdere soorten (maar niet alle) biodiversiteit. Ook deze KPI is bruikbaar. Een aanscherping van deze KPI in de vorm van de leeftijd van het grasland zou waardevol kunnen zijn, maar de huidige registratie omtrent leeftijd van grasland is te beperkt. RVO hanteert weliswaar het onderscheid van 5 jaar tussen tijdelijk en blijvend grasland, maar zodra grasland ouder wordt dan een zekere leeftijd, ontbreekt de leeftijd in de registratie.

- Voor groenbemester als nateelt in \% van oppervlakte voedergewas konden we binnen dit onderzoek geen zinvolle relaties met biodiversiteit berekenen. Op basis van onze bevindingen kunnen we dus niets zeggen over de bruikbaarheid ervan voor melkveebedrijven.

- Het stikstofbodemoverschot gaf op de verschillende grondsoorten op zowel perceels- als bedrijfsniveau heel wisselende resultaten, en geeft aan dat deze KPI minder bruikbaar is of heel specifiek per grondsoort moet worden toegepast. 
- Het percentage voereiwit geproduceerd op het eigen bedrijf als \% totaal voer is bekeken aan de hand van 2 afgeleide indicatoren: meetmelk per ha en grasopbrengst per ha. Meetmelk per ha bleek vrijwel nooit een relatie te hebben met biodiversiteit. Deze is dus op zichzelf niet bruikbaar als KPI maar geeft wel aan dat zowel extensieve als intensieve bedrijven goed kunnen scoren op biodiversiteit. De grasopbrengst per ha liet positieve relaties zien met bodem- en wormenindicatoren, maar geen of inconsistente relaties met de andere biodiversiteitscategorieën. Bij gebrek aan eenduidigheid is deze indicator daarom minder bruikbaar voor biodiversiteit op perceelsniveau maar kan, omdat er wel een relatie is met grasland in \% van totale bedrijfsoppervlakte, wel iets zeggen over biodiversiteit op bedrijfsniveau. De gevonden relaties suggereren wel dat meer biodiversiteit niet automatisch gerelateerd is aan een lagere productie, wat betekent dat ook met een hoge grasproductie de biodiversiteit goed kan zijn of zelfs dat een hoge biodiversiteit zorgt voor een hoge grasproductie.

De hier beschreven resultaten over de bruikbaarheid van de KPI's als indicator voor de gemeten biodiversiteit op melkveebedrijven zijn samengevat in Tabel 10 in hoofdstuk 5 . 


\section{$5 \quad$ Conclusies en aanbevelingen}

Het onderzoek toont relaties aan tussen KPI's en verschillende vormen van biodiversiteit. Deze relaties verschillen tussen grondsoorten en perceelstypen. Er is een trade-off tussen het stimuleren van de ene soort biodiversiteit ten opzichte van het stimuleren van een andere soort biodiversiteit. De relaties tussen KPI's en biodiversiteit blijken complex. Biodiversiteit is niet zwart-wit, maar kleurrijk. Het stimuleren van bedrijven om biodiversiteit te bevorderen, vergt maatwerk.

\subsection{Bruikbaarheid van KPI's als indicator voor biodiversiteit}

In onderstaande Tabel 10 staat op welke schaal de KPI's invloed hebben op de biodiversiteit en hoe we de bruikbaarheid van de KPI's op basis hiervan als indicator voor biodiversiteit op melkveebedrijven inschatten. Er is gekeken naar of significante relaties werden gevonden en of ze eenduidig zijn.

Tabel 10 Het verband tussen KPI's en biodiversiteit op perceels- en bedrijfsniveau ( + is een significant positief verband, - is een significant negatief verband en $+/$ - is een niet eenduidig verband, 0 is geen significant verband, een leeg vakje betekent niet onderzocht)

\begin{tabular}{|c|c|c|c|}
\hline \multirow[b]{2}{*}{ KPI } & \multicolumn{2}{|c|}{ Schaalniveau van werking } & \multirow{2}{*}{$\begin{array}{l}\text { Conclusie relatie tussen } \\
\text { KPI en biodiversiteit op } \\
\text { perceel per bedrijf }\end{array}$} \\
\hline & Perceel & Bedrijf & \\
\hline $\begin{array}{l}\text { 1. Grasland in } \% \text { van totale } \\
\text { bedrijfsoppervlakte }\end{array}$ & +1 & + & Ja, eenduidig. \\
\hline $\begin{array}{l}\text { 2. Blijvend grasland in } \% \text { van totale } \\
\text { bedrijfsoppervlakte }\end{array}$ & $++^{1}$ & + & Ja, eenduidig. \\
\hline $\begin{array}{l}\text { 3. Groenbemester als nateelt in \% van } \\
\text { oppervlakte voedergewas }\end{array}$ & $-1+$ & & $\begin{array}{c}\text { Nee, slechts beperkte relatie } \\
\text { met bodembiodiversiteit en } \\
\text { niet eenduidig. }\end{array}$ \\
\hline 4. Stikstofbodemoverschot per ha & $-1+$ & 0 & $\begin{array}{l}\text { Nee, geen eenduidige relatie } \\
\text { met biodiversiteit of niet } \\
\text { significant. }\end{array}$ \\
\hline 5. $\mathrm{NH}_{3}$-emissie per ha & \multicolumn{3}{|c|}{$\begin{array}{l}\text { Niet meegenomen in onderzoek vanwege verondersteld verwaarloosbaar } \\
\text { effect op bedrijfsniveau. }\end{array}$} \\
\hline $\begin{array}{l}\text { 6. Voereiwit geproduceerd op het eigen } \\
\text { bedrijf als } \% \text { totaal voer }\end{array}$ & & & $\begin{array}{c}\text { Nee op basis van } \\
2 \text { onderliggende indicatoren. }\end{array}$ \\
\hline Meetmelk per ha & $\begin{array}{l}0,-/+ \text { of niet } \\
\text { eenduidig }\end{array}$ & 0 & $\begin{array}{c}\text { Nee, meestal geen } \\
\text { significante relatie, niet } \\
\text { eenduidig. }\end{array}$ \\
\hline Gras N-productie per ha & $0 /+$ & $-1+$ & $\begin{array}{l}\text { Nee, meestal geen } \\
\text { significante relatie, soms } \\
\text { positief, niet eenduidig. }\end{array}$ \\
\hline
\end{tabular}

${ }^{1}$ Grasland ten opzichte van bouwland.

Het percentage grasland en het percentage blijvend grasland zijn bruikbaar als KPI voor biodiversiteit op bedrijfsniveau. Ze vertonen consistente en significante relaties met meerdere biodiversiteitscategorieën. Met name de leeftijd van grasland is bepalend voor de effecten op biodiversiteit: hoe ouder, hoe meer biodiversiteit. Het percentage groenbemester hebben we alleen onderzocht voor bodemdiversiteit. Daarvoor vonden we geen relaties. Het stikstofbodemoverschot bleek op perceels- en bedrijfsniveau onvoldoende consistente relaties met biodiversiteit te hebben. Op 
die niveaus is deze KPI dus niet bruikbaar. Hetzelfde geldt voor het percentage voereiwit van eigen bedrijf als indicator van biodiversiteit op perceels- of bedrijfsniveau. Er is nog onderzocht of meetmelk per hectare en grasproductie per hectare als alternatief konden dienen voor percentage voereiwit van eigen bedrijf. Er werden echter geen eenduidige relaties gevonden tussen deze alternatieve KPI's en de biodiversiteit op bedrijfsniveau. Voor de KPI's 4 en 6 is meer maatwerk nodig op perceels- en bedrijfsniveau ten aanzien van type biodiversiteit en grondsoort. Afhankelijk van de doelstelling rond biodiversiteit kunnen deze KPI's al dan niet worden ingezet. Er bleken meerdere 'trade-offs' tussen het effect van een KPI op de ene soort biodiversiteit (bijvoorbeeld wormen etende vogels) ten opzichte van een andere soort biodiversiteit (bijvoorbeeld insecten etende vogels). Stimuleren van bedrijven vergt dus maatwerk en keuzes ten aanzien van de soorten biodiversiteit, grondsoort en perceelstypen.

Overigens is het belangrijk om in gedachten te houden dat de huidige biodiversiteit het resultaat is van historisch gebruik. Biodiversiteit is onder andere gerelateerd aan het organischestofgehalte van de bodem. Een hoog gehalte geeft aan dat de grondgebruiker al jaren op een bepaalde manier de grond beheert en niet (alleen) ten tijde van het onderzoek. De lange tijd die nodig is om effecten op biodiversiteit zichtbaar te maken, betekent ook dat wanneer melkveehouders hun beheer aanpassen, de positieve effecten daarvan wellicht pas over 4 tot 5 jaar of nog later zichtbaar worden.

\subsection{Grondsoort en biodiversiteit}

Uit de resultaten van dit onderzoek blijkt dat de biodiversiteit op melkveebedrijven sterk afhankelijk is van grondsoort. Op basis hiervan adviseren we bij het vaststellen van doelen voor KPI's rekening met grondsoort te houden.

\subsection{Aanbevelingen voor communicatie en vervolgactiviteiten}

De bevindingen dat bodembiodiversiteit gepaard kan gaan met een hoge opbrengst, sterker nog, dat er een causaal verband is tussen bodembiodiversiteit en opbrengst, kan gebruikt worden in de communicatie over biodiversiteit met melkveehouders.

Behoud van grasland is belangrijk voor de biodiversiteit. De melkveehouderij kan naast biodiversiteit verzorgen op het eigen bedrijf ook biodiversiteit leveren aan de akkerbouw wanneer tijdelijk grasland wordt opgenomen in het bouwplan van de akkerbouwer. Met name blijvend grasland en zeker ouder blijvend grasland heeft een grote potentie als het gaat om bieden van biodiversiteit. Een vuistregel die heel goed in de communicatie past, is voor bedrijven met derogatie ( $80 \%$ grasland van totale bedrijfsoppervlakte en 20\% bouwland) om op minerale gronden het 60:20:20-principe toe te passen: $60 \%$ van het areaal van een melkveebedrijf bestaat uit blijvend grasland, $20 \%$ bestaat uit tijdelijk grasland met gras, rode en witte klaver en $20 \%$ bestaat uit bouwland, waarbij tijdelijk grasland en bouwland iedere drie jaar roteren.

Meetmelk per ha bleek vrijwel nooit een relatie te hebben met biodiversiteit. Deze is dus op zichzelf niet bruikbaar als KPI maar geeft wel aan dat zowel extensieve als intensieve bedrijven goed kunnen scoren op biodiversiteit op hun bedrijf.

Relaties met biodiversiteit buiten het bedrijf zijn niet onderzocht. Zijlstra et al. (2017) laten op basis van literatuurstudie zien dat de KPI's 4 tot en met 6 bruikbaar zijn voor het bevorderen van biodiversiteit vanwege de veronderstelde impact op biodiversiteit buiten het bedrijf. Ammoniak per hectare zoals berekend in de KringloopWijzer is daarom niet meegenomen. De impact op biodiversiteit van ammoniak per ha hangt daarbij ook af van de omgeving van het bedrijf ofwel wat de afstand is tot een natuurgebied. Voor stikstofbodemoverschot zijn eutrofiëringsnormen van belang (zie onder andere Kaderrichtlijn Water van belang (KRW). 
De database met gegevens van praktijkbedrijven die binnen dit onderzoek is opgebouwd, biedt mogelijkheden voor nadere analyses met betrekking tot biodiversiteit op melkveebedrijven. Daarbij kunnen we denken aan:

- Verdere verdieping van de samenhangen tussen bedrijfskenmerken (management) en biodiversiteit. Er is veel meegenomen in de huidige analyses, maar niet alles. De relaties tussen KPI's en biodiversiteit zijn bijvoorbeeld alleen onderzocht voor gemiddeld-graspercelen en niet voor de divers-graspercelen. Ook zijn niet alle vormen van biodiversiteit afzonderlijk en in alle relevante combinaties meegenomen.

- De plakvallen zijn nu geanalyseerd op basis van aantallen insecten in verschillende groottecategorieën. Wanneer ze geanalyseerd worden door de insecten te determineren op soortniveau, ontstaat meer inzicht in het diversiteitsaspect.

Tijdens de bedrijfsbezoeken zijn veel foto's gemaakt en visuele waarnemingen gedaan. Deze visuele informatie en ervaringen kunnen gebruikt worden om maatregelen te omschrijven en te illustreren in documentatie over biodiversiteit voor melkveehouders.

In dit onderzoek zijn verschillende vormen van meten van biodiversiteit op melkveebedrijven toegepast. Wanneer in de toekomst gerichter gewerkt gaat worden aan het verbeteren van de biodiversiteit op melkveebedrijven, wordt het relevant om op de bedrijven ook te kunnen monitoren wat de gevolgen zijn. De hier besproken meetmethoden zouden - eventueel samen met andere methoden die hiervoor internationaal worden gebruikt - beoordeeld kunnen worden op geschiktheid voor monitoringsdoeleinden.

Tegelijk met dit onderzoek (=deelproject 1 ) is onderzoek gedaan naar hoe boerenbestuurders de KPI's en (werken aan) biodiversiteit zien (=deelproject 2 ) en hoe andere landen biodiversiteit op melkveebedrijven bevorderen (=deelproject 3). Door de deelprojecten in hun samenhang te bekijken, kunnen gerichter stappen benoemd worden voor de verdere ontwikkeling van de biodiversiteitsmonitor. 


\section{Literatuur en websites}

Andersen N.C. (1983). Nitrogen turnover by earthworms in arable plots treated with farmyard manure and slurry. In: Earthworm ecology: from Darwin to vermiculture. Satchell, J.E (ed). Chapman and Hall. London: pp 67-105

Wit, J. de, N. van Eekeren, J. Wagenaar, F.W. Smeding (2013). Diverse grassland mixtures for higher yields and more stable sward quality. p. 180-182. In EGF - The Role of Grasslands in a Green Future. Akureyri, Iceland. 26 June 2013

Deru, J., N. van Eekeren en F. Lenssinck (2016). Mest voor weidevogelgebieden in veenweiden. Dikke fractie gescheiden drijfmest is alternatief voor ruige mest. V-Focus april 2016: 28-30

Eekeren, N. van, F. Verhoeven en J.W. Erisman (2015). Verkenning Kritische Prestatie Indicatoren voor stimulering van een biodiverse melkveehouderij. Louis Bolk Instituut, publicatienummer 2015-046 LbD.

Eekeren, N. van, J. Bokhorst, J. Deru, J. de Wit (2014). Regenwormen op het melkveebedrijf. Handreiking voor herkennen, benutten en managen. Louis Bolk Instituut 2014-004 LbD.

Eekeren, N. van, H. de Boer, M.C. Hanegraaf, J.G. Bokhorst, D. Nierop, J. Bloem, T. Schouten, R.G.M. de Goede en L. Brussaard (2010). Ecosystem services in grassland associated with biotic and abiotic soil parameters. Soil Biology \& Biochemistry. 42(9):1491-1504

Eekeren, N. van, L. Bommelé, J. Bloem, M. Rutgers, R.G.M. de Goede, D. Reheul en L. Brussaard (2008). Soil biological quality after 36 years of ley-arable cropping, permanent grassland and permanent arable cropping. Applied Soil Ecology. 40:432-446

Erisman, J.W., N. van Eekeren, W. Cuijpers en J. de Wit (2014). Biodiversiteit in de melkveehouderij Investeren in veerkracht en reduceren van risico's. Driebergen, Louis Bolk Instituut

Koopmans, C., M. Zanen en C. ter Berg (2005). De Kuil. Bodembeoordeling aan de hand van een kuil. Louis Bolk Instituut, rapport LB12

Kuiper, M.W. (2015). The value of field margins for farmland birds. PhD thesis, Wageningen University, ISBN 978-94-6257-239-3

Laarhoven, G. van, J. Nijboer, N. Oerlemans, R. Piechocki, J. Pluimers (2018). Biodiversiteitsmonitor melkveehouderij. Uitgave van Rabobank, FrieslandCampina en WNF. http: // biodiversiteitsmonitormelkveehouderij. nl / docs / Biodiversiteitsmonitor_engels.pdf (6 / 6 / 2018)

Michels, R. (2017). Automatic sticky trap analysis. Bsc Research report. Biology, Leiden University.

Moebius-Clune, B.N., D.J. Moebius-Clune, B.K. Gugino, O.J. Idowu, R.R. Schindelbeck, A.J. Ristow, H.M. van Es, J.E. Thies, H.A. Shayler, M.B. McBride, K.S.M. Kurtz, D.W. Wolfe en G.S. Abawi (2017). Comprehensive Assessment of Soil Health. The Cornell Framework. $3^{\text {rd }}$ edition. School of Integrative Plant Science, Cornell University, Ithaca, New York.

Smith, R.K., N.V. Jennings, A. Robinson en S. Harris (2004). Conservation of European hares Lepus europaeus in Britain: is increasing habitat heterogeneity in farmland the answer? Journal of Applied Ecology 41 (6): 1092-1102. DOI: 10,1111/ j.0021-8901.2004.00976.x. 
Woolridge, J.M. (2016). Introductory Econometrics; a modern approach. $6^{\text {th }}$ edition, Cengage learning, Boston

Zanen, M., (2017). Ontwikkeling van KPI's voor landschappelijke diversiteit en specifieke soorten. Als onderdeel van de Biodiversiteitsmonitor Melkveehouderij. Rapport Louis Bolk Instituut 2017-005 LbP.

Zijlstra, J. et al. (2016). Ontwikkeling waarderingssystematiek voor KPI's biodiversiteit. Notitie voor opdrachtgever PPS DZK Biodiversiteit

Zijlstra, J., P.W. Blokland, N. van Eekeren, G. Migchels, N. Polman, M. Bestman (2017). Monitoring van functionele agrobiodiversiteit in de melkveehouderij: ontwikkeling van KPI's. Wageningen Livestock Research, rapport 984 


\section{Bijlage 1 Steekproef Bedrijveninformatienet van Wageningen Economic Research}

Tabel 10 Verdeling van de bedrijven in het Bedrijveninformatienet op basis van 3 intensiteitsklassen, 3 grondsoorten en 4 percentielen van biodiversiteit op basis van KPI's (van I = laag scorende naar IV hoog scorende bedrijven)

\begin{tabular}{|c|c|c|c|}
\hline Intensiteit & Bodem & $\begin{array}{l}\text { Biodiversiteitspercentiel } \\
\text { op basis van KPI's }\end{array}$ & \\
\hline \multirow[t]{5}{*}{$<13.000$} & ZAND & I & 4 \\
\hline & & II & 5 \\
\hline & & III & 11 \\
\hline & & IV & 16 \\
\hline & & TOTAAL & 36 \\
\hline \multirow[t]{5}{*}{$13.000-16.000$} & ZAND & I & 4 \\
\hline & & II & 6 \\
\hline & & III & 9 \\
\hline & & IV & 5 \\
\hline & & TOTAAL & 24 \\
\hline \multirow[t]{5}{*}{$>16.000$} & ZAND & I & 19 \\
\hline & & II & 15 \\
\hline & & III & 7 \\
\hline & & IV & 8 \\
\hline & & TOTAAL & 49 \\
\hline \multirow[t]{5}{*}{$<13.000$} & KLEI & I & 3 \\
\hline & & II & 6 \\
\hline & & III & 1 \\
\hline & & IV & 9 \\
\hline & & TOTAAL & 19 \\
\hline \multirow[t]{5}{*}{$13.000-16.000$} & KLEI & I & 0 \\
\hline & & II & 5 \\
\hline & & III & 5 \\
\hline & & IV & 4 \\
\hline & & TOTAAL & 14 \\
\hline \multirow[t]{5}{*}{$>16.000$} & KLEI & I & 10 \\
\hline & & II & 3 \\
\hline & & III & 6 \\
\hline & & IV & 2 \\
\hline & & TOTAAL & 21 \\
\hline \multirow[t]{5}{*}{$<13.000$} & VEEN & I & 2 \\
\hline & & II & 5 \\
\hline & & III & 2 \\
\hline & & IV & 8 \\
\hline & & TOTAAL & 17 \\
\hline \multirow[t]{5}{*}{$13.000-16.000$} & VEEN & I & 2 \\
\hline & & II & 4 \\
\hline & & III & 2 \\
\hline & & IV & 3 \\
\hline & & TOTAAL & 11 \\
\hline \multirow[t]{5}{*}{$>16000$} & VEEN & I & 3 \\
\hline & & II & 1 \\
\hline & & III & 2 \\
\hline & & IV & 0 \\
\hline & & TOTAAL & 6 \\
\hline
\end{tabular}




\section{Bijlage 2 Resultaten ANOVA's in tabelvorm}

Tabel 11 Gemiddeldes van biodiversiteitsindicatoren wormen, planten en insecten op gemiddeld en divers grasland per grondsoort (SD tussen haakjes)

\begin{tabular}{|c|c|c|c|c|c|c|c|c|c|}
\hline \multirow{2}{*}{$\begin{array}{l}\text { Grondsoort } \\
\text { Graslandtype }\end{array}$} & \multicolumn{2}{|c|}{ Klei } & \multicolumn{2}{|c|}{ Veen } & \multicolumn{2}{|c|}{ Zand } & \multicolumn{3}{|c|}{ P-waarden } \\
\hline & Gemiddeld & Divers & Gemiddeld & Divers & Gemiddeld & Divers & Perceel & Grond & $P \times G$ \\
\hline \multicolumn{10}{|l|}{ Wormen } \\
\hline Aantal soorten wormen & $3,9 \quad(1,4)$ & $4,5 \quad(1,2)$ & $3,5 \quad(1)$ & $3,6 \quad(1,3)$ & $3,3 \quad(0,9)$ & $3,4 \quad(1,1)$ & & & \\
\hline Aantal wormen (aantal per m2) & $411(279,2)$ & $521 \quad(277,2)$ & $627(300,7)$ & $799(427)$ & $355(183,7)$ & $354(144,3)$ & 0,06 & 0,09 & \\
\hline Wormbiomassa (g per m2) & $87 \quad(45,9)$ & $123(92,6)$ & $109(42,3)$ & $143(83,7)$ & $103(83,4)$ & $92(43,8)$ & & & \\
\hline Wormgewicht (g per worm) & $0,24 \quad(0,1)$ & $0,22 \quad(0,1)$ & $0,19 \quad(0,1)$ & $0,18 \quad(0)$ & $0,29 \quad(0,1)$ & $0,26 \quad(0,1)$ & & * & \\
\hline \multicolumn{10}{|l|}{ Planten } \\
\hline Aantal soorten planten & $5,3 \quad(1,4)$ & $5,9 \quad(1,3)$ & $5,2 \quad(1,3)$ & $6,3 \quad(3)$ & $6,1 \quad(2,2)$ & $8,6 \quad(2,7)$ & $* *$ & $* *$ & * \\
\hline Aantal soorten grassen & $3,9 \quad(1)$ & $4,0 \quad(0,8)$ & $3,7 \quad(1,1)$ & $4,3 \quad(1,8)$ & $3,5 \quad(1,2)$ & $4,5 \quad(1,2)$ & & & \\
\hline Aantal soorten kruiden & $0,8 \quad(0,8)$ & $1,4(1)$ & $1,3 \quad(1,1)$ & $1,8 \quad(1,4)$ & $2,3 \quad(1,4)$ & $3,6 \quad(2,6)$ & $* *$ & $* *$ & \\
\hline \multicolumn{10}{|l|}{ Insecten } \\
\hline Aantal soorten insecten, zuigvallen & $2,0 \quad(0,9)$ & $2,3 \quad(1,7)$ & $1,9 \quad(1,3)$ & $2,3 \quad(0,9)$ & $2,3 \quad(1,8)$ & $2,9 \quad(1,6)$ & & & \\
\hline Aantal insecten, zuigvallen & $4,5 \quad(2,7)$ & $6,0 \quad(6,1)$ & $5,8 \quad(5,8)$ & $7,2 \quad(3,7)$ & $6,6(6)$ & 8,2 (3) & * & & \\
\hline Aantal insecten, plakstrips & $900(211)$ & $1008(230,9)$ & $863 \quad(118,3)$ & $937 \quad(122,4)$ & $829(73,9)$ & $819(127,3)$ & $*$ & & \\
\hline Aantal insecten $4-10 \mathrm{~mm}$, plakstrips & $52,9 \quad(15,9)$ & $59,0 \quad(10,8)$ & $68,2 \quad(26,2)$ & $81,3 \quad(25,9)$ & $80,0 \quad(19,5)$ & $71,4 \quad(17,6)$ & & * & \\
\hline
\end{tabular}

Aantal insecten $4-10 \mathrm{~mm}$, plakstrips

$2,9(15,9)$

$59,0(10,8)$

$68,2(26,2)$ 
Tabel 12 Gemiddeldes van bodembiodiversiteitsindicatoren op gemiddeld en divers grasland per grondsoort (SD tussen haakjes)

\begin{tabular}{|c|c|c|c|c|c|c|c|c|c|c|c|c|}
\hline \multirow{2}{*}{$\begin{array}{l}\text { Grondsoort } \\
\text { Graslandtype }\end{array}$} & \multicolumn{3}{|c|}{ Klei } & \multicolumn{3}{|c|}{ Veen } & \multicolumn{3}{|c|}{ Zand } & \multicolumn{3}{|c|}{ P-waarden } \\
\hline & Gemiddeld & Divers & Bouw & Gemiddeld & Divers & Bouw & Gemiddeld & Divers & Bouw & Perceel & Grond & PxG \\
\hline \multicolumn{13}{|l|}{ Soil health index } \\
\hline Watercapaciteit & $0,32 \quad(0,06)$ & $0,35 \quad(0,05)$ & $0,28 \quad(0,03)$ & $0,32 \quad(0,04)$ & $0,34 \quad(0,07)$ & $0,25 \quad(0,07)$ & $0,17 \quad(0,06)$ & $0,16 \quad(0,06)$ & $0,13 \quad(0,05)$ & $* * *$ & $* * *$ & ns \\
\hline Aggregaatstabiliteit & $71,0 \quad(15,3)$ & $81,5 \quad(10,6)$ & $48,6 \quad(22,3)$ & $92,4 \quad(6,2)$ & $94,7 \quad(4,7)$ & $72,8 \quad(28,4)$ & $72,5 \quad(11,8)$ & $68,4 \quad(12,6)$ & $35,6 \quad(18,6)$ & $* * *$ & $* * *$ & ns \\
\hline Ace bodem eiwitindex & $15,5 \quad(7,8)$ & $16,9 \quad(4,4)$ & $8,2 \quad(3,4)$ & $34,5 \quad(9,6)$ & $39,4 \quad(12,3)$ & $31,4 \quad(12)$ & $19,0 \quad(5,6)$ & $15,0 \quad(3,4)$ & $12,2 \quad(3,8)$ & $* * *$ & $* * *$ & 0,08 \\
\hline Respiratie & $1,6 \quad(0,4)$ & $1,9 \quad(0,2)$ & $0,8 \quad(0,3)$ & $1,7 \quad(0,5)$ & $1,7 \quad(0,7)$ & $0,9 \quad(0,3)$ & $1,0 \quad(0,5)$ & $0,9 \quad(0,3)$ & $0,4 \quad(0,3)$ & $* * *$ & $* * *$ & ns \\
\hline Organische stof & $7,8 \quad(3,3)$ & $10,3 \quad(3,6)$ & $5,6 \quad(2,8)$ & $21,8 \quad(6,5)$ & 22,0 & $17,8 \quad(11,2)$ & $5,2 \quad(2,9)$ & $4,2 \quad(1,1)$ & $2,8 \quad(0,8)$ & $* *$ & $* * *$ & ns \\
\hline Actieve koolstof & $920(175)$ & $1027(91)$ & $665(158)$ & $1046(255)$ & $1075(262)$ & 994 (229) & $690(143)$ & $761 \quad(225)$ & $510 \quad(82)$ & $* * *$ & $* * *$ & ns \\
\hline Bio score & $94(7,9)$ & $98 \quad(1,8)$ & $72(20,8)$ & $97(5,7)$ & $96(5,7)$ & $89(13,2)$ & $82(8)$ & $82(10)$ & $54(17,2)$ & $* * *$ & $* * *$ & 0,07 \\
\hline \multicolumn{13}{|l|}{ Structuur } \\
\hline Structuur $0-20 \mathrm{~cm}$ & $7,0 \quad(1,2)$ & $7,1 \quad(0,7)$ & & $7,6 \quad(0,8)$ & $7,3 \quad(0,8)$ & & $7,1 \quad(0,9)$ & $6,4 \quad(1)$ & & ns & ns & ns \\
\hline Beworteling $0-20 \mathrm{~cm}$ & $7,1 \quad(1,2)$ & $7,1 \quad(0,9)$ & & $7,6 \quad(0,5)$ & $7,3 \quad(0,6)$ & & $7,1 \quad(0,8)$ & $6,9 \quad(0,9)$ & & ns & ns & ns \\
\hline Eurofins: bodemleven & $142(45,4)$ & $195(51,2)$ & $80 \quad(38)$ & $310(105,4)$ & $322(115,6)$ & $167(80,6)$ & $127(57,9)$ & $133(33,1)$ & $52(18,5)$ & $* * *$ & $* * *$ & ns \\
\hline
\end{tabular}

Tabel 13 Gemiddeldes van biodiversiteitsindicatoren vogels, hazen en reeën per grondsoort (SD tussen haakjes)

\begin{tabular}{|c|c|c|c|c|c|}
\hline Grondsoort & Klei & Veen & Zand & & P-waarden \\
\hline \multicolumn{6}{|l|}{ Vogels } \\
\hline Aantal soorten insecteneters & $2,1 \quad(0,6)$ & $1,9 \quad(0,3)$ & 2,2 & $(0,6)$ & ns \\
\hline Aantal soorten wormeneters & $3,5(1)$ & $3,8 \quad(1,2)$ & 3,3 & (1) & 0,08 \\
\hline Aantal soorten roofvogels & $1,7 \quad(1,2)$ & $1,7 \quad(1,1)$ & 1,1 & $(0,8)$ & ns \\
\hline Aantal soorten totaal & $7,3 \quad(1,9)$ & $7,5 \quad(1,7)$ & 6,7 & $(1,2)$ & ns \\
\hline \multicolumn{6}{|l|}{ Zoogdieren } \\
\hline Aantal hazen & $6,7 \quad(4,9)$ & $9,6 \quad(5,3)$ & 6,4 & (3) & ns \\
\hline Aantal reeën & $4,5 \quad(3,3)$ & $4,2 \quad(4,6)$ & 8,4 & $(8,6)$ & ns \\
\hline
\end{tabular}




\section{Bijlage 3 Resultaten correlaties in tabelvorm}

Tabel 14 Correlaties van biodiversiteitsindicatoren planten, wormen en insecten met KPI's, bodemparameters en omgeving

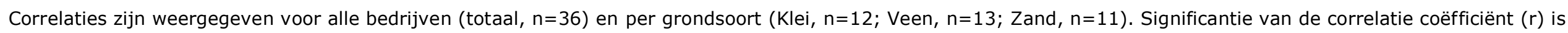
aangegeven met $*(P<0,05)$ en $* *(P<0,01)$

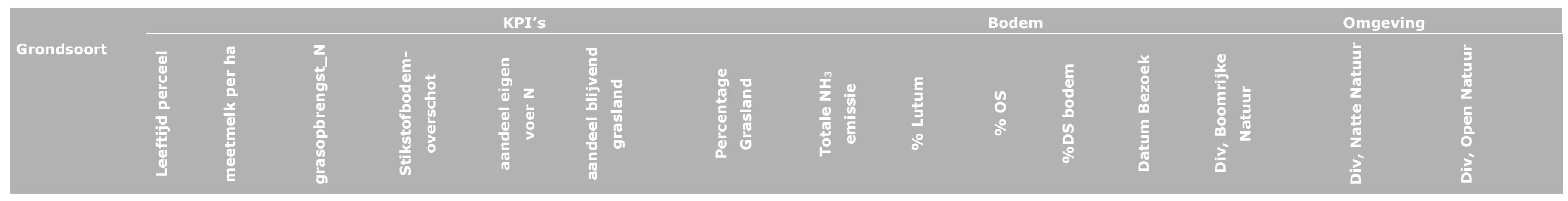

Aantal planten soorten

\begin{tabular}{|c|c|c|c|c|c|c|c|c|c|c|c|c|c|c|c|}
\hline Totaal & $-0,15$ & 0,15 & $-0,31$ & $-0,21$ & $-0,18$ & $-0,04$ & 0,15 & 0,04 & $-0,23$ & $-0,13$ & $0,36^{*}$ & $-0,06$ & 0,28 & $-0,14$ & 0,04 \\
\hline Klei & $-0,05$ & $-0,26$ & $-0,48$ & $-0,55$ & 0,16 & $-0,12$ & 0,57 & $-0,07$ & 0,00 & $-0,29$ & 0,34 & 0,26 & 0,08 & $-0,45$ & $-0,15$ \\
\hline Veen & $-0,45$ & 0,02 & $-0,39$ & $-0,15$ & $-0,27$ & $-0,32$ & $-0,38$ & $-0,17$ & $-0,02$ & $-0,09$ & 0,45 & 0,07 & 0,35 & $-0,17$ & 0,24 \\
\hline Zand & 0,38 & 0,31 & 0,07 & $-0,03$ & $-0,06$ & 0,30 & 0,41 & 0,31 & $-0,36$ & 0,30 & 0,27 & $-0,25$ & 0,13 & 0,05 & $-0,03$ \\
\hline
\end{tabular}

Aantal soorten gras

\begin{tabular}{|c|c|c|c|c|c|c|c|c|c|c|c|c|c|c|c|}
\hline Totaal & 0,01 & 0,00 & 0,11 & 0,01 & 0,12 & 0,24 & 0,21 & 0,20 & 0,20 & 0,00 & 0,00 & 0,19 & $-0,28$ & $-0,27$ & $-0,02$ \\
\hline Klei & 0,22 & 0,50 & 0,03 & 0,18 & $-0,59^{*}$ & 0,25 & 0,39 & $0,61^{*}$ & 0,11 & 0,02 & $-0,13$ & 0,38 & $-0,25$ & $-0,51$ & 0,07 \\
\hline Veen & $-0,11$ & $-0,45$ & 0,14 & $-0,24$ & 0,45 & 0,26 & 0,27 & $-0,14$ & 0,33 & $-0,08$ & 0,07 & $-0,15$ & $-0,30$ & $-0,10$ & $-0,02$ \\
\hline Zand & 0,21 & 0,03 & $-0,08$ & 0,08 & 0,03 & 0,28 & $-0,08$ & 0,10 & $-0,13$ & 0,28 & 0,19 & 0,34 & $-0,28$ & $-0,16$ & $-0,02$ \\
\hline \multicolumn{16}{|c|}{ Aantal soorten kruiden } \\
\hline Totaal & $-0,13$ & 0,27 & $-0,40^{*}$ & $-0,10$ & $-0,39^{*}$ & $-0,12$ & $-0,04$ & $-0,03$ & $-0,54^{* *}$ & $-0,03$ & $0,35^{*}$ & $-0,14$ & $0,44^{* *}$ & 0,05 & 0,07 \\
\hline Klei & 0,00 & $-0,55$ & $-0,45$ & $-0,52$ & 0,53 & $-0,01$ & 0,31 & $-0,53$ & $-0,27$ & $-0,30$ & 0,38 & 0,18 & $-0,15$ & 0,00 & $-0,04$ \\
\hline Veen & $-0,47$ & $0,58^{*}$ & $-0,46$ & 0,21 & $-0,72^{* *}$ & $-0,75^{* *}$ & $-0,68^{*}$ & 0,06 & $-0,51$ & 0,12 & 0,45 & 0,33 & $0,78^{* *}$ & $-0,07$ & 0,31 \\
\hline Zand & 0,52 & 0,39 & 0,18 & $-0,06$ & $-0,10$ & 0,30 & 0,59 & 0,43 & $-0,39$ & 0,36 & 0,09 & $-0,54$ & 0,23 & 0,04 & $-0,17$ \\
\hline
\end{tabular}




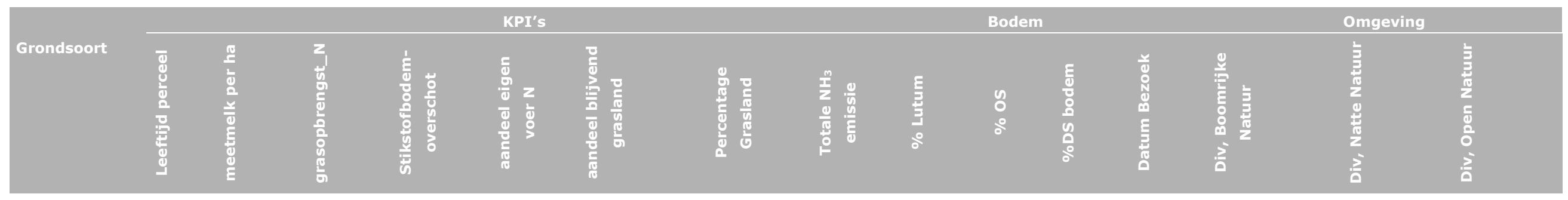

Aantal wormen

\begin{tabular}{|c|c|c|c|c|c|c|c|c|c|c|c|c|c|c|c|}
\hline Totaal & 0,24 & 0,11 & 0,05 & 0,26 & $-0,03$ & 0,02 & 0,23 & 0,23 & 0,29 & 0,31 & $-0,39^{*}$ & $-0,18$ & $-0,10$ & 0,05 & 0,06 \\
\hline Klei & $-0,18$ & 0,43 & 0,11 & 0,09 & $-0,44$ & $-0,39$ & 0,03 & 0,25 & 0,09 & 0,09 & $-0,08$ & 0,09 & 0,34 & $-0,33$ & $-0,16$ \\
\hline Veen & 0,27 & $-0,28$ & $-0,16$ & $-0,26$ & 0,03 & 0,11 & $-0,04$ & $-0,01$ & 0,39 & $-0,11$ & $-0,16$ & $-0,30$ & 0,08 & 0,46 & $0,61^{*}$ \\
\hline Zand & 0,06 & $0,72^{*}$ & $-0,06$ & $-0,07$ & $-0,37$ & 0,02 & $0,76^{* *}$ & 0,52 & $-0,38$ & 0,10 & $-0,13$ & $-0,45$ & 0,16 & 0,14 & $-0,24$ \\
\hline \multicolumn{16}{|c|}{ Aantal soorten wormen } \\
\hline Totaal & $0,34^{*}$ & $-0,13$ & $0,35^{*}$ & $-0,19$ & 0,23 & 0,13 & $-0,02$ & 0,24 & 0,29 & $-0,06$ & $-0,18$ & $-0,08$ & $-0,01$ & 0,29 & $-0,12$ \\
\hline Klei & 0,42 & $-0,11$ & 0,41 & $-0,20$ & 0,22 & 0,24 & $-0,30$ & 0,50 & 0,29 & 0,37 & $-0,52$ & 0,19 & 0,17 & 0,30 & $-0,44$ \\
\hline Veen & $\mathbf{0 , 5 7 ^ { * }}$ & $-0,61 *$ & $-0,11$ & $-0,40$ & 0,23 & 0,35 & 0,18 & $-0,35$ & 0,44 & $-0,24$ & $-0,12$ & $-0,20$ & $-0,15$ & 0,36 & 0,49 \\
\hline
\end{tabular}

Hoeveelheid wormen $\left(\mathrm{g} \mathrm{m}^{-2}\right)$

\begin{tabular}{|c|c|c|c|c|c|c|c|c|c|c|c|c|c|c|c|}
\hline Totaal & 0,23 &, $442^{* *}$ & 0,01 & 0,15 & $-0,25$ & $-0,02$ & 0,14 &, $437^{* *}$ & $-0,07$ & 0,19 & $-0,20$ &,$- 353^{*}$ & 0,05 & 0,13 & $-0,10$ \\
\hline Klei & 0,18 & 0,43 & 0,17 & 0,09 & $-0,45$ & $-0,40$ & $-0,28$ & 0,43 & $-0,02$ & 0,22 & $-0,34$ & 0,10 & 0,13 & $-0,15$ & $-0,21$ \\
\hline Veen & 0,27 & $-0,22$ & $-0,16$ & 0,05 & $-0,06$ & $-0,14$ & $-0,16$ & $-0,02$ & 0,13 & 0,11 & $-0,25$ & $-0,35$ & $-0,02$ & 0,49 &, $815^{* *}$ \\
\hline Zand & 0,33 & ,743** & 0,15 & 0,11 & $-0,32$ & 0,24 &, $628^{*}$ &, $708^{*}$ & $-0,31$ & 0,44 & $-0,23$ & $-0,56$ & 0,11 & 0,13 & $-0,44$ \\
\hline \multicolumn{16}{|c|}{ Wormgewicht ( $\mathrm{g}$ worm $^{-1}$ ) } \\
\hline Totaal & 0,06 & 0,16 & $-0,01$ & $-0,17$ & $-0,17$ & $-0,01$ & $-0,19$ & 0,17 &,$- 372^{*}$ & $-0,16$ & 0,22 & $-0,17$ & 0,21 & 0,09 & $-0,13$ \\
\hline Klei & 0,38 & $-0,10$ & 0,02 & $-0,03$ & 0,00 & 0,12 & $-0,26$ & 0,21 & $-0,12$ & 0,17 & $-0,32$ & 0,20 & $-0,28$ & 0,20 & $-0,01$ \\
\hline Veen & $-0,05$ & 0,03 & $-0,13$ & 0,17 & $-0,16$ & $-0,44$ & $-0,25$ & $-0,24$ &,$- 612^{*}$ & 0,27 & 0,05 & $-0,01$ & 0,28 & $-0,18$ & 0,02 \\
\hline Zand & 0,47 & 0,21 & 0,43 & 0,17 & $-0,01$ & 0,34 & 0,10 & 0,47 & $-0,26$ & 0,35 & $-0,03$ & $-0,53$ & 0,12 & 0,05 & $-0,38$ \\
\hline \multicolumn{16}{|c|}{ Ins_PS_N_ Totaal_Tot Plakvalmethode } \\
\hline Totaal & 0,22 & $-0,06$ & $-0,04$ & 0,14 & 0,12 & 0,12 & 0,01 & $-0,03$ & $-0,16$ & 0,23 & $-0,22$ & $-0,25$ & $-0,06$ & $-0,02$ & $-0,27$ \\
\hline Klei & 0,39 & $-0,21$ & $-0,24$ & $-0,22$ & 0,09 & $-0,01$ & $-0,15$ & $-0,05$ & $-0,37$ & $-0,15$ & 0,05 & 0,17 & $-0,29$ & 0,25 & 0,08 \\
\hline Veen & 0,18 & $-0,27$ & $-0,08$ & $-0,31$ & 0,30 & $-0,09$ & $-0,01$ & $-0,48$ & $-0,38$ & 0,24 & $-0,24$ & $-0,39$ & 0,27 & $-0,19$ & $-0,30$ \\
\hline Zand & $-0,07$ & 0,44 & 0,16 & 0,43 & $-0,38$ & 0,34 & 0,04 & 0,56 & $-0,23$ & $-0,13$ & 0,07 & $-0,39$ & 0,06 & $-0,08$ & $-0,53$ \\
\hline
\end{tabular}




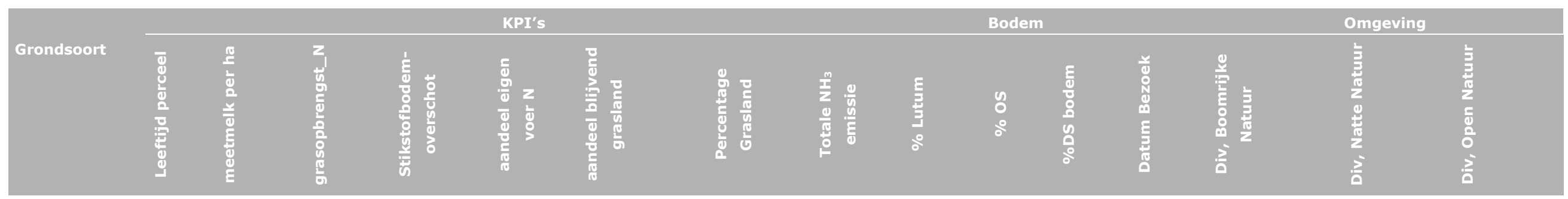

Ins_PS_N_4-10mm_Tot Plakvalmethode

\begin{tabular}{|c|c|c|c|c|c|c|c|c|c|c|c|c|c|c|c|}
\hline Totaal & $-0,03$ & 0,09 & $-0,09$ & $-0,04$ & 0,01 & 0,03 & $-0,15$ & $-0,04$ & $-0,18$ & $-0,10$ & 0,15 & 0,12 & $-0,06$ & 0,08 & $-0,11$ \\
\hline Klei & 0,24 & $-0,43$ & $-0,22$ & $-0,34$ & 0,54 & 0,11 & 0,13 & $-0,48$ & $-0,15$ & $-0,02$ & 0,06 & $-0,03$ & $-0,17$ & 0,12 & $-0,19$ \\
\hline Veen & $-0,02$ & 0,37 & $-0,19$ & ,703** & $-0,29$ & $-0,55$ & $-0,38$ & $-0,06$ & $-0,54$ & 0,32 & $-0,01$ & 0,14 & $-0,05$ & 0,33 & 0,52 \\
\hline Zand & 0,01 & 0,34 & 0,02 & 0,48 & $-0,18$ & 0,42 & $-0,25$ & 0,42 & 0,03 & 0,24 & $-0,06$ & 0,22 & $-0,33$ & $-0,11$ & $-0,48$ \\
\hline \multicolumn{16}{|c|}{ InsNspec Zuigmethode } \\
\hline Totaal & $-0,01$ & 0,25 & $-0,18$ & $-0,05$ & $-0,11$ & 0,01 & 0,17 & $-0,07$ & 0,01 & $-0,09$ & 0,15 & $-0,11$ & 0,26 & 0,21 & 0,00 \\
\hline Klei & 0,08 & $-0,09$ & $-0,24$ & $-0,13$ & 0,08 & 0,01 & 0,30 & $-0,43$ & $-0,11$ & $-0,05$ & 0,11 & 0,02 & 0,29 & 0,09 & $-0,21$ \\
\hline Veen & 0,09 & $-0,03$ & 0,12 & $-0,37$ & 0,19 & 0,18 & 0,13 & 0,08 & 0,31 & 0,01 & $-0,04$ & $-0,07$ & 0,27 & 0,22 & $-0,07$ \\
\hline Zand & $-0,20$ & 0,48 & $-0,45$ & 0,25 & $-0,32$ & 0,03 & 0,24 & 0,03 & 0,15 & $-0,14$ & 0,28 & $-0,15$ & 0,19 & 0,32 & 0,05 \\
\hline \multicolumn{16}{|c|}{ InsNtot Zuigmethode } \\
\hline Totaal & 0,16 & 0,00 & $-0,11$ & 0,01 & 0,00 & 0,08 & $-0,01$ & $-0,13$ & 0,13 & 0,04 & $-0,07$ & 0,00 & 0,21 & 0,12 & 0,09 \\
\hline Klei & $-0,04$ & $-0,16$ & $-0,45$ & $-0,07$ & $-0,03$ & $-0,21$ & 0,19 & $-0,52$ & $-0,26$ & $-0,21$ & 0,32 & $-0,15$ & 0,27 & 0,15 & 0,09 \\
\hline Veen & 0,25 & $-0,15$ & 0,06 & $-0,49$ & 0,16 & 0,09 & 0,09 & $-0,03$ & 0,34 & $-0,04$ & $-0,10$ & $-0,17$ & 0,26 & 0,23 & 0,36 \\
\hline Zand & 0,00 & 0,11 & 0,16 & 0,27 & 0,04 & 0,33 & $-0,18$ & $-0,04$ &, $916^{* *}$ & 0,44 & $-0,42$ & 0,35 & 0,14 & $-0,06$ & $-0,19$ \\
\hline
\end{tabular}


Tabel 15 Correlaties van de biodiversiteitsindicatoren vogels, reeën en hazen met KPI's, bodemparameters en de omgeving

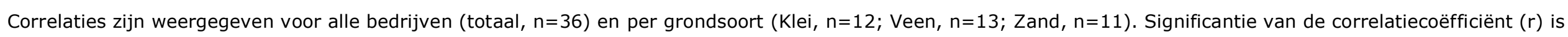
aangegeven met $*(P<0,05)$ en $* *(P<0,01)$.

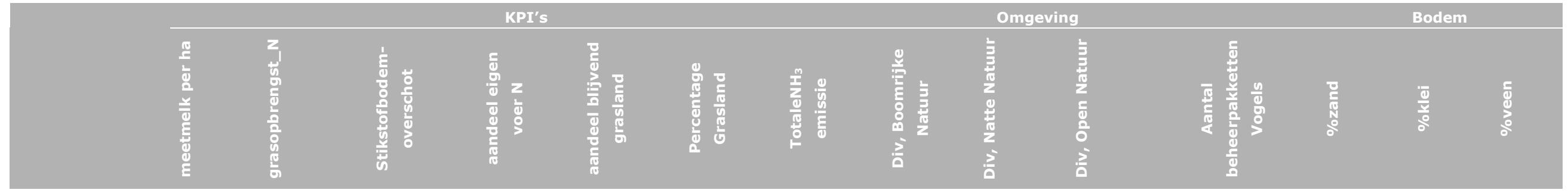

Vogels: aantal soorten insecteneters

\begin{tabular}{|c|c|c|c|c|c|c|c|c|c|c|c|c|c|c|}
\hline Totaal & $-0,05$ & $-0,10$ & $-0,06$ & $-0,15$ & $-0,15$ &,$- 387^{*}$ & 0,05 & 0,11 & $-0,13$ & $-0,09$ & $-0,08$ & 0,16 & 0,04 & $-0,21$ \\
\hline Klei & $-0,28$ & 0,02 & $-0,11$ & 0,14 & $-0,31$ & $-0,40$ & 0,04 & 0,18 & $-0,06$ & 0,15 & 0,46 & $-0,06$ & 0,10 & $-0,09$ \\
\hline Veen & $-0,01$ & $-0,43$ & 0,05 & $-0,36$ & $-0,20$ & $-0,24$ & $-0,21$ & 0,25 & 0,24 & 0,27 & 0,28 & 0,12 & 0,21 & $-0,23$ \\
\hline Zand & $-0,01$ & 0,01 & 0,33 & $-0,14$ & 0,29 & $-0,42$ & 0,22 & $-0,43$ & $-0,45$ & $-0,47$ &,$- 702^{*}$ & 0,10 & & $-0,10$ \\
\hline
\end{tabular}

Vogels: aantal soorten wormeneters

\begin{tabular}{|c|c|c|c|c|c|c|c|c|c|c|c|c|c|c|}
\hline Totaal & $-0,01$ & 0,32 & 0,25 & 0,23 & 0,33 & 0,27 & ,388* &,$- 414^{*}$ & $-0,30$ &,$- 339^{*}$ & $-0,04$ &,$- 343^{*}$ & 0,07 & 0,29 \\
\hline Klei & $-0,20$ & 0,36 & $-0,40$ & 0,32 & $-0,01$ & $-0,02$ & 0,49 & $-0,25$ & $-0,47$ & $-0,44$ & $-0,37$ & $-0,49$ &, $687^{*}$ & $-0,46$ \\
\hline Veen & $-0,20$ & ,639* & 0,01 &, $623^{*}$ & 0,43 & ,604* & 0,22 & $-0,49$ & $-0,05$ & $-0,26$ & 0,05 &,$- 670^{*}$ & 0,15 & 0,40 \\
\hline Zand & 0,49 & $-0,26$ & ,663* & $-0,54$ &, $617^{*}$ & $-0,06$ & 0,48 & $-0,39$ & $-0,45$ & $-0,36$ & $-0,20$ & $-0,57$ & & 0,57 \\
\hline
\end{tabular}

\begin{tabular}{|c|c|c|c|c|c|c|c|c|c|c|c|c|c|c|}
\hline Totaal & $-0,08$ & $-0,24$ & $-0,03$ & 0,04 & $-0,11$ & 0,06 & $-0,05$ & 0,00 & 0,11 & 0,22 & $-0,11$ & $-0,18$ & 0,14 & 0,05 \\
\hline Klei & $-0,19$ & $-0,48$ & $-0,09$ & $-0,20$ & $-0,07$ & 0,19 & 0,19 & 0,10 & 0,13 & 0,24 & $-0,10$ & $-0,09$ & 0,20 & $-0,21$ \\
\hline Veen & $-0,03$ & $-0,52$ & $-0,14$ & $-0,18$ & $-0,53$ & $-0,49$ &,$- 600^{*}$ & 0,47 & 0,07 & 0,41 & $-0,14$ & 0,30 & $-0,08$ & $-0,17$ \\
\hline Zand & 0,19 & $-0,11$ & $-0,39$ & 0,10 & $-0,32$ & 0,47 & 0,02 & 0,02 & 0,27 & 0,20 & $-0,25$ & 0,44 & & $-0,44$ \\
\hline \multicolumn{15}{|c|}{ Vogels: aantal soorten } \\
\hline Totaal & $-0,04$ & $-0,02$ & 0,12 & 0,07 & 0,07 & 0,08 & 0,22 & $-0,18$ & $-0,12$ & $-0,11$ & $-0,12$ & $-0,23$ & 0,12 & 0,12 \\
\hline Klei & $-0,35$ & $-0,15$ & $-0,26$ & 0,10 & $-0,13$ & $-0,07$ & 0,30 & 0,00 & $-0,04$ & 0,03 & $-0,03$ & $-0,23$ & 0,43 & $-0,40$ \\
\hline Veen & $-0,16$ & 0,02 & $-0,10$ & 0,24 & $-0,10$ & 0,05 & $-0,29$ & 0,09 & 0,01 & 0,07 & $-0,05$ & $-0,18$ & 0,06 & 0,10 \\
\hline Zand & ,630* & $-0,31$ & 0,43 & $-0,60$ & 0,39 & 0,19 & 0,60 & $-0,48$ & $-0,44$ & $-0,40$ &,$- 644^{*}$ & $-0,07$ & & 0,07 \\
\hline
\end{tabular}




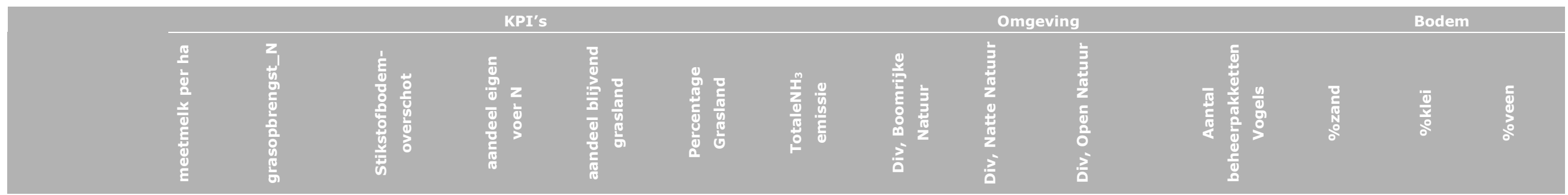

Aantal reeën

\begin{tabular}{|c|c|c|c|c|c|c|c|c|c|c|c|c|c|c|}
\hline Totaal & $-0,01$ & $-0,23$ &,$- 442^{* *}$ & $-0,01$ &,$- 425^{*}$ & $-0,21$ &,$- 450^{* *}$ & , $469^{* *}$ & ,359* & ,379* & 0,05 & , 374* & $-0,18$ & $-0,22$ \\
\hline Klei & 0,34 & 0,03 & $-0,14$ & $-0,17$ & 0,06 & 0,12 & 0,02 & 0,11 & $-0,04$ & $-0,07$ & 0,04 & 0,00 & 0,05 & $-0,08$ \\
\hline Veen & 0,33 &,$- 811^{* *}$ & 0,22 &,$- 748^{* *}$ &,$- 795^{* *}$ &,$- 848^{* *}$ & $-0,42$ &, $591^{*}$ & 0,12 & 0,46 & $-0,18$ &, $583^{*}$ & $-0,33$ & $-0,22$ \\
\hline Zand & $-0,36$ & 0,32 &,$- 837^{* *}$ &, $792^{* *}$ & $-0,56$ & 0,22 & $-0,57$ & 0,45 & ,745** & 0,43 & 0,36 & 0,20 & & $-0,20$ \\
\hline \multicolumn{15}{|c|}{ Aantal hazen } \\
\hline Totaal & 0,11 & 0,23 & 0,30 & 0,04 & 0,04 & 0,12 & ,485** & $-0,07$ & 0,09 & $-0,09$ & 0,22 & $-0,25$ & $-0,12$ & ,382* \\
\hline Klei & 0,06 & 0,09 & $-0,01$ & $-0,09$ & $-0,19$ & $-0,24$ & 0,47 & 0,26 & 0,05 & $-0,32$ & $-0,10$ & $-0,17$ & 0,29 & $-0,25$ \\
\hline Veen & 0,43 & 0,39 & 0,53 & $-0,11$ & $-0,16$ & 0,07 &, $810^{* *}$ & $-0,14$ & 0,11 & 0,18 & 0,19 & $-0,40$ & $-0,27$ & 0,47 \\
\hline Zand & 0,21 & 0,31 & $-0,15$ & 0,09 & 0,18 & 0,60 & 0,26 & 0,43 & 0,15 & $-0,18$ & 0,33 & $-0,17$ & & 0,17 \\
\hline
\end{tabular}


Tabel 16 Correlaties van bodem biodiversiteitsindicatoren met KPI's en bodem parameters

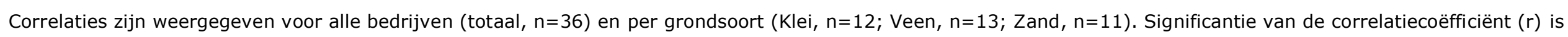
aangegeven met $*(P<0,05)$ en $* *(P<0,01)$.

\begin{tabular}{|c|c|c|c|c|c|c|c|c|c|c|c|c|}
\hline & & & & & PI's & & & & & & Bodem & \\
\hline & 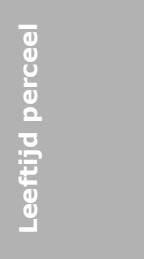 & 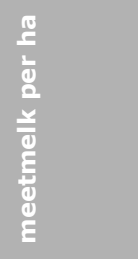 & 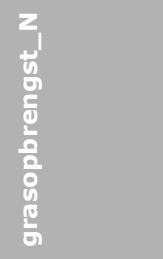 & 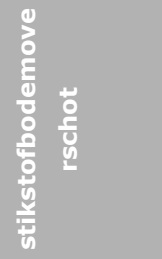 & 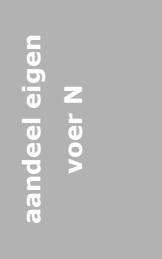 & 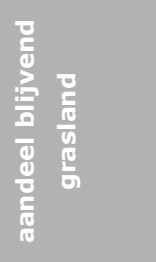 & 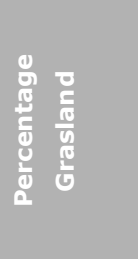 & 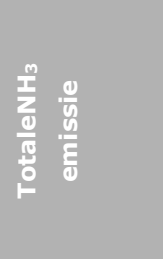 & 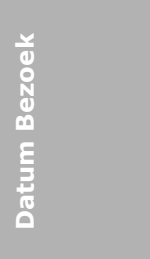 & 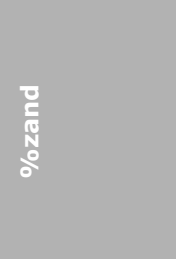 & $\frac{\frac{0}{8}}{\frac{0}{0}}$ & 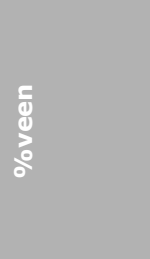 \\
\hline Water & & & & & & & & & & & & \\
\hline Alles & 0,24 & $-0,25$ & ,495** & 0,21 &, $513^{* *}$ & 0,23 & 0,25 & 0,15 & 0,12 &,$- 774^{* *}$ & $\mathbf{4 4 5}^{* *}$ &, $363^{*}$ \\
\hline Klei & 0,10 & 0,00 & 0,07 & $-0,10$ & $-0,04$ & $-0,01$ & 0,22 & 0,17 & 0,04 & $-0,41$ & 0,31 & 0,06 \\
\hline Veen & 0,49 & $-0,13$ & 0,41 & $-0,05$ & 0,43 & 0,16 & 0,30 & $-0,08$ & $-0,46$ & $-0,31$ & $-0,18$ & 0,35 \\
\hline Zand & 0,05 & $-0,16$ & 0,36 & $-0,20$ & 0,27 & $-0,10$ & $-0,13$ & $-0,19$ & 0,30 & 0,41 & & $-0,41$ \\
\hline Orgar & & & & & & & & & & & & \\
\hline Alles & 0,31 & $-0,12$ & 0,26 & ,660** & 0,24 &, $347^{*}$ & 0,06 & 0,14 & $-0,08$ &,$- 506^{* *}$ & $-0,28$ & ,835** \\
\hline Klei & 0,34 & $-0,19$ & ,663* & $-0,25$ & 0,37 & 0,42 & $-0,07$ & 0,44 & 0,19 & $-0,52$ & ,579* & $-0,23$ \\
\hline Veen & 0,05 & 0,46 & 0,09 & 0,20 & $-0,09$ & $-0,51$ & $-0,37$ & $-0,12$ & $-0,51$ & $-0,08$ &,$- 574^{*}$ & 0,43 \\
\hline Zand & 0,52 & 0,20 & 0,35 & 0,31 & $-0,06$ & 0,42 & $-0,14$ & 0,30 & 0,11 & $-0,01$ & & 0,01 \\
\hline Aggre & biliteit & & & & & & & & & & & \\
\hline Alles &, $405^{*}$ & 0,08 & 0,17 &, $552^{* *}$ & $-0,01$ & $456^{* *}$ & 0,25 & ,348* & 0,14 & $-0,32$ & $-0,23$ & ,575** \\
\hline Klei & ,592* & 0,24 &, $585^{*}$ & $-0,09$ & $-0,10$ & 0,36 & 0,24 &, $755^{* *}$ & 0,45 & $-0,48$ &, $653^{*}$ & $-0,41$ \\
\hline Veen & 0,16 & $-0,01$ & $-0,13$ & $-0,20$ & $-0,23$ & $-0,01$ & $-0,11$ & $-0,09$ & 0,30 & 0,07 & 0,23 & $-0,20$ \\
\hline Zand & 0,60 & 0,55 & $-0,37$ & 0,44 & $-0,36$ & 0,41 & 0,30 & 0,34 & $-0,11$ & $-0,25$ & & 0,25 \\
\hline Ace $b$ & witindex & & & & & & & & & & & \\
\hline Alles &, $338^{*}$ & $-0,02$ & 0,02 &, $625^{* *}$ & $-0,01$ & 0,25 & $-0,07$ & 0,12 & $-0,05$ & $-0,20$ &,$- 453^{* *}$ &, $684^{* *}$ \\
\hline Klei & ,630* & $-0,09$ & 0,26 & 0,09 & 0,10 & 0,28 & $-0,28$ & 0,32 & 0,27 & $-0,10$ & 0,27 & $-0,32$ \\
\hline Veen & 0,03 & 0,30 & $-0,14$ & 0,13 & $-0,25$ &,$- 603^{*}$ & $-0,46$ & $-0,30$ & $-0,14$ & 0,32 &,$- 614^{*}$ & 0,16 \\
\hline Zand & 0,53 & 0,48 & $-0,04$ & 0,43 & $-0,45$ & 0,24 & 0,04 &, $660^{*}$ & $-0,26$ & $-0,22$ & & 0,22 \\
\hline Respi & & & & & & & & & & & & \\
\hline Alles & 0,32 & $-0,26$ & ,439** & 0,21 &, $436^{* *}$ & ,359* & 0,30 & 0,28 &, $365^{*}$ &,$- 612^{* *}$ &, $334^{*}$ & 0,32 \\
\hline Klei & 0,57 & $-0,20$ & 0,03 & $-0,27$ & 0,06 & 0,07 & 0,28 & 0,37 & 0,44 & $-0,38$ & 0,53 & $-0,35$ \\
\hline Veen & 0,27 & $-0,17$ & 0,54 & $-0,26$ & 0,36 &, $603^{*}$ & ,593* & 0,45 & 0,27 & $-0,48$ & 0,50 & 0,04 \\
\hline
\end{tabular}



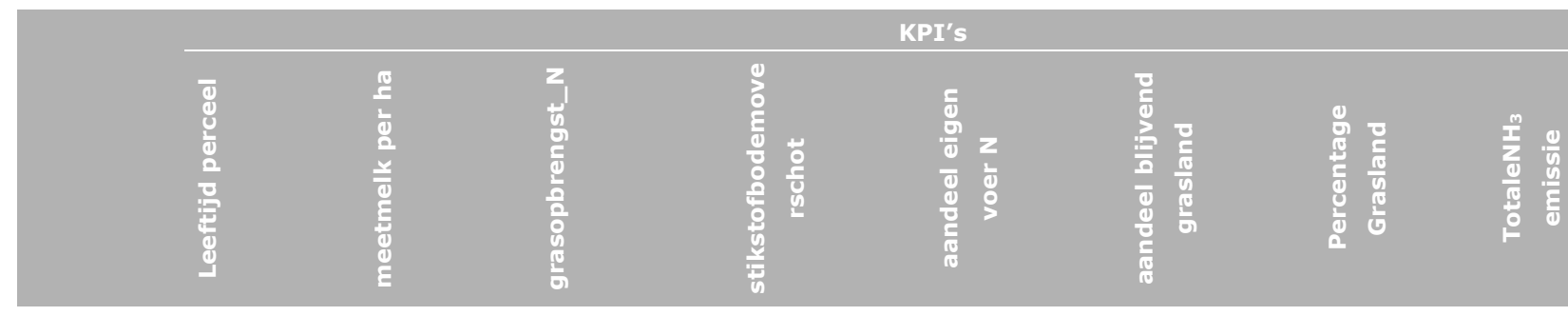

$\begin{array}{lll}0,10 & 0,23 & 0,25\end{array}$

$-0,30$

$-0,08$

0,37

$-0,19$

\begin{tabular}{|c|c|c|c|c|c|c|c|c|c|c|c|c|}
\hline & 0,20 & $-0,08$ & 0,42 & 0,10 & 0,23 & 0,25 & $-0,30$ & $-0,08$ & & & & \\
\hline \multicolumn{13}{|c|}{ Actieve koolstof } \\
\hline Alles &, $671^{*}$ & 0,11 & 0,36 & 0,03 & $-0,12$ & 0,51 & 0,15 & 0,45 &, $597^{*}$ & $-0,17$ & 0,45 & $-0,51$ \\
\hline Klei &, $3^{*}{ }^{*}$ & $-0,11$ & 0,20 & ,386* & 0,20 & 0,32 & 0,04 & 0,06 & $-0,11$ &,$- 527^{* *}$ & 0,13 &, $427^{* *}$ \\
\hline Veen & 0,15 & $-0,08$ & $-0,37$ & 0,03 & $-0,04$ & $-0,47$ & $-0,45$ &,$- 660^{*}$ &,$- 674^{*}$ & 0,06 & $-0,23$ & 0,10 \\
\hline Zand &, $626^{*}$ & 0,23 & 0,02 & 0,27 & $-0,17$ & 0,29 & 0,11 & 0,22 & $-0,17$ & $-0,16$ & & 0,16 \\
\hline \multicolumn{13}{|c|}{ Bio-index } \\
\hline Alles &, $372^{*}$ & $-0,10$ & 0,18 &, $424^{*}$ & 0,17 &, $334^{*}$ & 0,03 & 0,07 & $-0,09$ &,$- 520^{* *}$ & 0,10 & ,470** \\
\hline Klei &, $681^{*}$ & 0,11 & 0,39 & 0,02 & $-0,10$ & 0,50 & 0,14 & 0,48 &, $587^{*}$ & $-0,21$ & 0,47 & $-0,50$ \\
\hline Veen & 0,15 & $-0,06$ & $-0,41$ & 0,03 & $-0,07$ & $-0,50$ & $-0,48$ &,$- 675^{*}$ &,$- 672^{*}$ & 0,07 & $-0,26$ & 0,11 \\
\hline Zand &, $645^{*}$ & 0,27 & 0,00 & 0,30 & $-0,19$ & 0,32 & 0,12 & 0,25 & $-0,17$ & $-0,17$ & & 0,17 \\
\hline \multicolumn{13}{|c|}{ EF_Bodemleven } \\
\hline Alles & $0,51^{* *}$ & $-0,22$ & 0,29 & $0,57^{* *}$ & $0,37^{*}$ & $0,35^{*}$ & 0,25 & 0,12 & $-0,14$ & $-0,42^{* *}$ & $-0,27$ & $0,74^{* *}$ \\
\hline Klei & $0,78^{* *}$ & $-0,16$ & 0,33 & 0,06 & 0,15 & 0,56 & $-0,02$ & 0,38 & 0,43 & $-0,15$ & 0,37 & $-0,40$ \\
\hline Veen & 0,44 & $-0,17$ & $0,58^{*}$ & $-0,22$ & 0,57 & $-0,06$ & 0,36 & $-0,01$ & $-0,71^{*}$ & $-0,41$ & $-0,17$ & 0,43 \\
\hline Zand & $0,61^{*}$ & $-0,12$ & 0,02 & 0,40 & 0,06 & 0,53 & $-0,12$ & $-0,01$ & $-0,08$ & $-0,51$ & $0,67^{*}$ & 0,35 \\
\hline
\end{tabular}




\section{Bijlage 4 Resultaten regressieanalyses in tabelvorm}

Tabel 17 Regressiemodel 1 voor wormen, planten en insecten $(P<0,1 ; * P<0,05 ; * * P<0,01 ; * * * P<0,001)$

$1 \%$ Lutum en $\%$ OS onder een KPI refereert naar de interactieterm met de KPI.

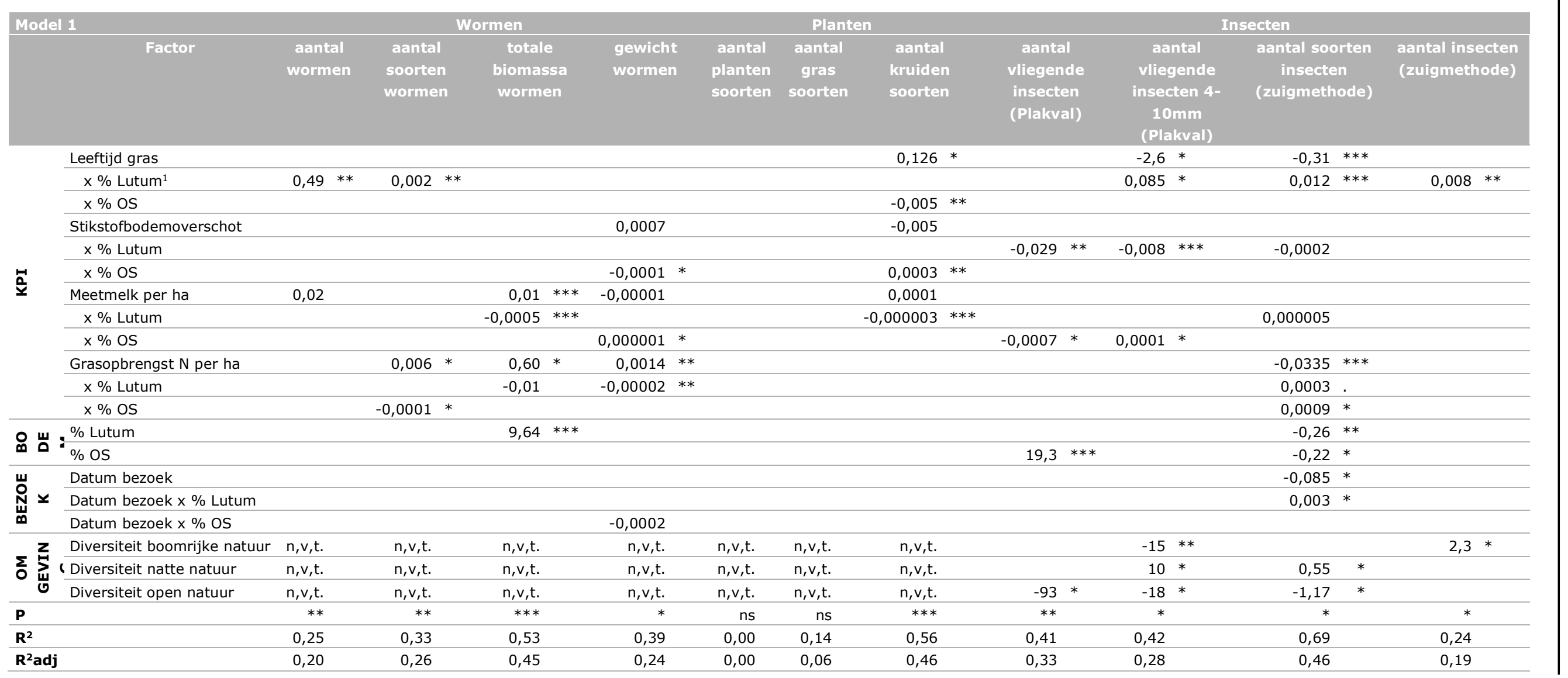


Tabel 18 Regressiemodel 2 voor wormen, planten en insecten $(P<0,1 ; * P<0,05 ; * * P<0,01 ; * * * P<0,001)$

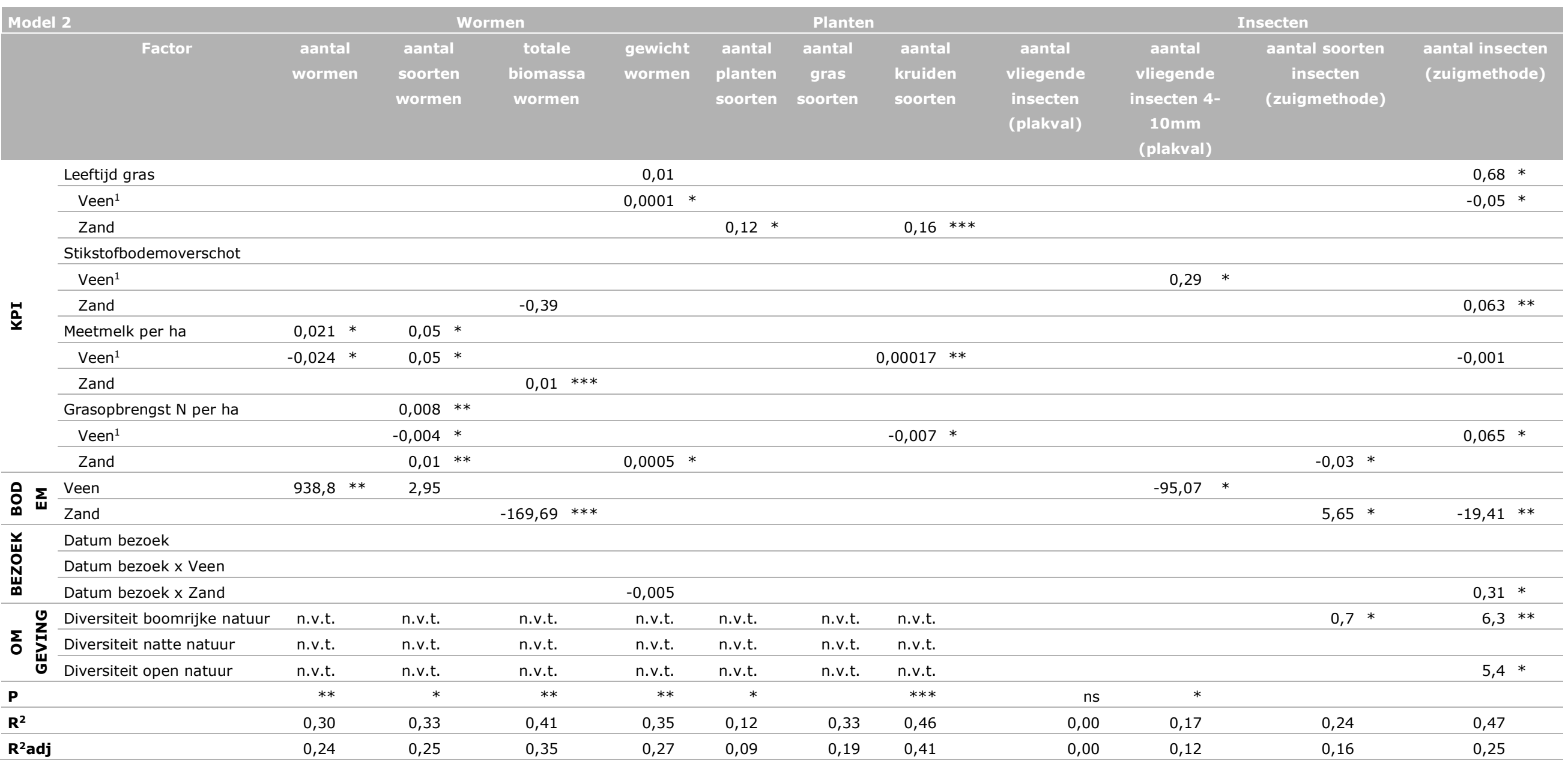

De regressiecoëfficiënten voor veen en zand onder een KPI geven de absolute effecten van de desbetreffende KPI op veen of zand (in de gevallen waar deze significant afwijkt van het hoofdeffect voor alle grondsoorten). 
Tabel 19 Regressiemodel 3 voor vogels en wild $(P<0,1 ; * P<0,05 ; * * P<0,01 ; * * * P<0,001)$

\begin{tabular}{|c|c|c|c|c|c|c|c|c|}
\hline \multirow[t]{2}{*}{ Model 3} & \multirow[b]{2}{*}{ Factor } & \multicolumn{4}{|c|}{ Vogels } & \multicolumn{3}{|c|}{ Zoogdieren } \\
\hline & & insecteneters & wormeneters & roofvogels & totaal & aantal hazen & aantal ree & \\
\hline \multirow{15}{*}{$\underline{\underline{\underline{y}}}$} & grasland in \% van totale bedrijfsoppervlakte & $-2,36 *$ & $0,000002 * *$ & & & & & \\
\hline & $x \%$ Veen $^{1}$ & & & & & $-0,40$ & 1,00 & ** \\
\hline & $x \%$ Zand & $-0,01$ & $-0,05 * * *$ & & & & & \\
\hline & blijvend grasland in $\%$ van totale bedrijfsoppervlakte & & & & & & 8,02 & * \\
\hline & $x \%$ Veen $^{1}$ & & & $-0,08 *$ & & & $-0,72$ & $*$ \\
\hline & x \% Zand & & & & & 0,10 & & \\
\hline & Stikstofbodemoverschot & & & & & 0,04 & $-0,1$ & $* * *$ \\
\hline & $x \%$ Veen $^{1}$ & & & & & & & \\
\hline & $\mathrm{x} \%$ Zand & & & $-0,0001 *$ & & $-0,001$ & $*$ & \\
\hline & Meetmelk per ha & $-0,00004$ & $-0,00009$ & & & & 0,00146 & $* * *$ \\
\hline & $x \%$ Veen $^{1}$ & & & $-0,0000025$ & & & $-0,00001$ & 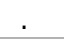 \\
\hline & $\mathrm{x} \%$ Zand & 0,000001 & & & & & $-0,00001$ & $* * *$ \\
\hline & Grasopbrengst N per ha & & & $-0,01$ & & & $-0,10$ & $* * *$ \\
\hline & $x \%$ Veen $^{1}$ & & & & & 0,001 & * & \\
\hline & $\mathrm{x} \%$ Zand & & & & & & 0,0010 & $* * *$ \\
\hline \multirow{2}{*}{ 욤 } & $\%$ Veen & & & $0,11 *$ & & & & \\
\hline & $\%$ Zand & & & & & & & \\
\hline \multirow{3}{*}{ 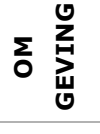 } & Diversiteit boomrijke natuur & & & & & & & \\
\hline & Diversiteit natte natuur & & & & & & 1,4 & \\
\hline & Diversiteit open natuur & & & & & & & \\
\hline \multirow{2}{*}{\multicolumn{2}{|c|}{$\begin{array}{l}\mathbf{P} \\
\mathbf{R}^{2}\end{array}$}} & & $* *$ & * & ns & * & $* * *$ & \\
\hline & & 0,25 & 0,32 & 0,33 & & 0,34 & 0,75 & \\
\hline \multicolumn{2}{|l|}{$\mathbf{R}^{2} \mathbf{a d j}$} & 0,15 & 0,26 & 0,22 & & 0,23 & 0,65 & \\
\hline
\end{tabular}

${ }^{1}$ De regressiecoëfficiënten voor \% veen en \% zand onder een KPI geven de interactie-effecten met de desbetreffende KPI op veen of zand (in de gevallen waar deze significant afwijkt van het hoofdeffect voor alle grondsoorten). 
Tabel 20 Regressiemodel 4 voor vogels en wild $(P<0,1 ; * P<0,05 ; * * P<0,01 ; * * * P<0,001)$

Model $4 \quad$ Vogels

\begin{tabular}{|c|c|c|c|c|c|c|c|c|c|}
\hline \multirow[t]{2}{*}{ Model 4} & \multirow[b]{2}{*}{ Factor } & \multicolumn{5}{|c|}{ Vogels } & \multicolumn{3}{|c|}{ Wild } \\
\hline & & insecteneters & wormeneter & & roofvogels & totaal & aantal hazen & aantal reeé & \\
\hline \multirow{15}{*}{$\frac{\vec{a}}{\underline{x}}$} & grasland in \% van totale bedrijfsoppervlakte & $-2,05 *$ & & & & & & & \\
\hline & Veen $^{1}$ & & & & 9,05 & $*$ & & 70,08 & $*$ \\
\hline & Zand & & & & & & & $-106,64$ & $* * *$ \\
\hline & blijvend grasland in \% van totale bedrijfsoppervlakte & & & & & & & 8,10 & $*$ \\
\hline & Veen $^{1}$ & & & & $-8,54$ & $*$ & & $-78,05$ & $* * *$ \\
\hline & Zand & & $1,29 *$ & & & & & 28,70 & $* * *$ \\
\hline & Stikstofbodemoverschot & & & & $-0,01$ & $*$ & & $-0,07$ & $* *$ \\
\hline & Veen $^{1}$ & & & & & & $0,06 *$ & & \\
\hline & Zand & & & & & & & $-0,199$ & $* * *$ \\
\hline & Meetmelk per ha & & & & & & & 0,001 & $* * *$ \\
\hline & Veen $^{1}$ & & & & & & & $-0,001$ & $* *$ \\
\hline & Zand & & & & & & & & \\
\hline & Grasopbrengst N per ha & & $0,006 *$ & * & $-0,01$ & $* *$ & & $-0,102$ & $* * *$ \\
\hline & Veen $^{1}$ & & & & & & & & \\
\hline & Zand & & & & & & & & \\
\hline \multirow{2}{*}{ 욨 } & Veen & & & & & & $-14,44$ & 28,53 & . \\
\hline & Zand & & & & $-1,23$ & $* *$ & & 97,74 & $* * *$ \\
\hline \multirow{4}{*}{ 乏 } & Diversiteit boomrijke natuur & & $-0,7$ & $* *$ & & & & $-3,03$ & $* *$ \\
\hline & Diversiteit natte natuur & & & & & & & 1,92 & $* *$ \\
\hline & Diversiteit open natuur & & & & & & & $-3,81$ & $* *$ \\
\hline & Beheerspakketten vogels & & & & & & & 2,70 & $* *$ \\
\hline $\mathbf{P}$ & & $*$ & $* *$ & & $*$ & ns & * & $* * *$ & \\
\hline $\mathbf{R}^{2}$ & & 0,15 & 0,33 & & 0,37 & & 0,22 & 0,91 & \\
\hline$R^{2}$ adj & & 0,13 & 0,26 & & 0,26 & & 0,17 & 0,82 & \\
\hline
\end{tabular}

De regressie coëfficiënten voor \% veen en \% zand onder een KPI, geven de interactie-effecten met de desbetreffende KPI op veen of zand (in de gevallen waar deze significant afwijkt van het hoofdeffect voor alle grondso orten). 


\section{Bijlage 5 Beschrijving resultaten op basis van correlaties en regressieanalyses}

\section{Bodemgezondheid}

\section{Watercapaciteit (Tabel 16)}

Er bleek een positieve correlatie met grasopbrengst $(0,50)$ op alle bedrijven en met het aandeel eigen voer $(0,51)$ op alle bedrijven. Er bleek een negatieve correlatie met $\%$ zand $(-0,77)$ op alle bedrijven, een positieve correlatie met het $\%$ klei $(0,45)$ op alle bedrijven en een positieve correlatie met $\%$ veen $(0,36)$ op alle bedrijven.

\section{Aggregaatstabiliteit (Tabel 16)}

Er bleek een positieve correlatie met leeftijd van het grasland op alle bedrijven $(0,41)$ en op klei $(0,59)$. Er bleek een positieve correlatie met grasopbrengst op klei $(0,59)$, een positieve correlatie met stikstofbodemoverschot op alle bedrijven $(0,55)$, een positieve correlatie met het aandeel blijvend grasland op alle bedrijven $(0,46)$, een positieve correlatie met $\mathrm{NH}_{3}$-emissie op alle bedrijven $(0,35)$ en op klei $(0,76)$. Tenslotte bleek er een positieve correlatie te zijn met \% klei op klei $(0,65)$ en $\%$ veen op veen $(0,58)$.

\section{Eiwitindex (Tabel 16)}

Er bleek een positieve correlatie met leeftijd van het grasland op alle bedrijven $(0,34)$ en op klei $(0,63)$ en een positieve correlatie met stikstofbodemoverschot op alle bedrijven $(0,63)$. Er bleek een negatieve correlatie met aandeel blijvend grasland op veen $(0,60)$. Er bleek een positieve correlatie met $\mathrm{NH}_{3}$-emissie op zand $(0,66)$. Er bleek een negatieve correlatie met \% klei op alle bedrijven $(-0,45)$ en op veen $(-0,61)$ en een positieve correlatie met $\%$ veen op alle bedrijven $(0,68)$.

\section{Respiratie (Tabel 16)}

Er bleek een positieve correlatie met grasopbrengst op alle grondsoorten $(0,44)$, met het aandeel blijvend grasland op alle grondsoorten $(0,36)$ en op veen $(0,60)$ en een positieve correlatie met grasland in \% van totale bedrijfsoppervlakte op veen $(0,59)$. Er bleek een positieve correlatie met bezoekdatum op alle bedrijven $(0,37)$. Tenslotte bleek er een negatieve correlatie met $\%$ zand op alle bedrijven $(-0,61)$ en een positieve correlatie met $\%$ klei op alle bedrijven $(0,33)$.

\section{Organische stof (Tabel 16)}

Er bleek een positieve correlatie met grasopbrengst op klei $(0,66)$, met stikstofbodemoverschot op alle bedrijven $(0,66)$ en met aandeel blijvend grasland $(0,35)$ op alle bedrijven. Er bleek een negatieve correlatie met $\%$ zand $(-0,51)$ op alle bedrijven, een positieve correlatie met $\%$ klei $(0,58)$ op klei, een negatieve correlatie met $\%$ klei $(-0,57)$ op veen en een positieve correlatie met $\%$ veen $(0,84)$ op alle bedrijven.

\section{Actieve koolstof (Tabel 16)}

Er bleek een positieve correlatie met leeftijd van het grasland op alle bedrijven $(0,67)$, op klei $(0,35)$ en op zand $(0,63)$. Er bleek een positieve correlatie met stikstofbodemoverschot op klei $(0,39)$ en een negatieve correlatie met $\mathrm{NH}_{3}$-emissie op veen $(-0,66)$. Er bleek een positieve correlatie met bezoekdatum op alle bedrijven $(0,60)$ en een negatieve correlatie met bezoekdatum op veen $(-0,67)$. Tenslotte bleek er een negatieve correlatie met \% zand op klei $(-0,53)$ en een positieve correlatie met $\%$ veen op klei $(0,43)$.

\section{Bio-index (Tabel 16)}

De 'bio-index' is een index berekend op basis van de 6 bovenstaande fysische en biologische indicatoren uit de Soil Health Index. Er bleek een positieve correlatie met leeftijd van het grasland op alle grondsoorten $(0,37)$, op klei $(0,68)$ en op zand $(0,65)$. Er bleek een positieve correlatie met 
stikstofbodemoverschot op alle grondsoorten $(0,42)$ en met het aandeel blijvend grasland op alle grondsoorten $(0,33)$. Er bleek een negatieve correlatie met $\mathrm{NH}_{3}$-emissie op veen $(-0,68)$. Voorts bleek er een positieve correlatie met bezoekdatum op klei $(0,59)$ en een negatieve correlatie met bezoekdatum op veen $(-0,68)$. Tenslotte bleek er een negatieve correlatie met $\%$ zand op alle bedrijven $(-0,52)$ en positieve correlatie met $\%$ veen op alle bedrijven $(0,47)$.

\section{Structuur 0-20 cm (Tabel 12)}

Er werden geen significante correlaties gevonden met de KPI's.

\section{Beworteling 0-20 cm (Tabel 12)}

Er werden geen significante correlaties gevonden met de KPI's.

\section{Regenwormen}

\section{Aantal wormen}

- Correlatie: Het aantal wormen was positief gecorreleerd met meetmelk per ha op zand $(r=0,72$; $\mathrm{P}<0,05)$.

- Regressie: Het aantal wormen werd in model $1\left(R^{2}{ }_{a d j}=0,20, P<0,01\right)$ beschreven aan de hand van leeftijd van het grasland in interactie met het \% lutum $(P<0,01$; hoe ouder en hoe hoger het \% lutum, des te meer wormen) en meetmelk per ha ( $P<0,1$; hoe meer meetmelk, hoe meer wormen). Het aantal wormen werd in model $2\left(R^{2}\right.$ adj $\left.=0,24 ; P<0,01\right)$ beschreven aan de hand van meetmelk per ha $(P<0,05$; hoe meer meetmelk, hoe meer wormen), maar op veen was er juist een negatief effect van meetmelk per ha (interactie $P<0,05$ ). Er was een significant effect van grondsoort $(P<0,001 ;$ meer wormen op veen dan op zand en klei).

- Samengevat nam het aantal wormen toe met toenemende graslandleeftijd (model 1). Er was een overwegend positief effect van meetmelk per ha (correlatie, model1: maar model 2 negatief veen). Er was geen significant effect van grasopbrengst $\mathrm{N}$ en stikstofbodemoverschot op het aantal wormen. Het aantal wormen was het hoogste op veen, gevolgd door klei en zand.

\section{Aantal soorten wormen}

- Correlatie: Het aantal soorten wormen was positief gecorreleerd met de leeftijd van grasland $(r=0,34 ; P<0,05)$ en de grasopbrengst $(r=0,35 ; P<0,05)$ op alle bedrijven, positief met de leeftijd van grasland op veen $(r=0,57 ; P<0,05)$ en negatief met meetmelk per ha $(r=-0,61 ; P<0,05)$ op veen.

- Regressie: In model $1\left(\mathrm{R}^{2}\right.$ adj=0,26; $\left.\mathrm{P}<0,001\right)$ werd het aantal soorten wormen beschreven door de graslandleeftijd in interactie met \% lutum $(P<0,01$; hoe hoger de leeftijd van gras, hoe groter het aantal soorten wormen, effect van leeftijd werd sterker bij hoger lutumgehalte). Tevens was er een positief effect van grasopbrengst $N(P<0,05)$, maar er was een negatieve interactie van grasopbrengst met \% organische stof $(P<0,05)$ die dit effect afzwakte bij lager OS-gehalte in de bodem. In model $2\left(R^{2}\right.$ adj $\left.=0,25 ; P<0,05\right)$ was er een positief effect van meetmelk per ha $(P<0,05)$ op klei en veen, bovendien was er een positief effect van grasopbrengst op zand en klei, en licht negatief op veen.

- Samengevat was er een overwegend positief effect van graslandleeftijd op het aantal soorten wormen (correlatie, model1) en van de grasopbrengst op zand en klei (correlatie, beide modellen). Het effect van meetmelk was niet consistent (overwegend negatief in de correlaties, maar juist positief in model 2) en er was de tendens voor een negatief effect van stikstofbodemoverschot (correlaties).

\section{Wormenbiomassa (g per $\mathbf{~ m}^{\mathbf{2}}$ )}

- Correlatie: De wormenbiomassa was positief gecorreleerd met meetmelk per ha $(r=0,44 ; p<0,05$ op alle bedrijven en met meetmelk per ha $(r=0,74 ; P<0,05)$ op zand.

- Regressie: In model $1\left(R^{2}\right.$ adj $\left.=0,45 ; P<0,001\right)$ werd de wormenbiomassa beschreven door de meetmelk per ha $(P<0,001)$ in interactie met het \% lutum, wat grofweg betekende dat er op zand een positief effect was van meetmelk per ha, maar op klei en veen een negatief effect. Er was ook een positief verband met grasopbrengst $N(P<0,05)$, in interactie met \% lutum (effect het sterkst op zand). In model $2\left(R^{2}\right.$ adj $\left.=0,41 ; P<0,01\right)$ was er een trend voor een negatief effect van 
stikstofbodemoverschot op zand $(P<0,1)$, een positief verband met meetmelk per ha op zand $(P<0,01)$.

- Samengevat was er geen tot weinig effect van graslandleeftijd (wel trend positieve correlaties), en stikstofbodemoverschot (trend negatief op zand, model 2). Meetmelk per ha had een positief effect op zand maar op veen juist een negatief effect (correlatie, beide modellen). Ook grasopbrengst vertoonde een positief verband met wormenbiomassa, met name op zand (model 1 ).

\section{Gewicht van wormen (g per worm)}

- Correlatie: Het gewicht per worm was niet significant gecorreleerd aan de KPI's.

- Regressie: In model $1\left(R^{2}\right.$ adj $\left.=0,24 ; P<0,05\right)$ was er een positief verband met stikstofbodemoverschot $(P<0,1)$ in negatieve interactie met \% OS hetgeen omgerekend betekende dat er op klei en zand een positief effect was en op veen een negatief effect. Meetmelk per ha had een overwegend negatief effect op wormgewicht $(P<0,1)$ op zand en klei, maar een positieve interactie met \% OS resulteerde in een positief effect op veen. Grasopbrengst vertoonde een positief verband met wormgewicht $(P<0,01)$, met name op zandgrond (negatieve interactie met \% lutum). Het wormgewicht had de tendens af te nemen naarmate de metingen later in het jaar werden uitgevoerd (datum bezoek $P<0,1)$, met name op veen. In model $2\left(R^{2}\right.$ adj $\left.=0,27 ; P<0,01\right)$ was er een positief verband met grasleeftijd, met name op veen $(P<0,05)$ en een positief verband met grasopbrengst $N$ op zand $(P<0,05)$. Er was een tendens voor een negatief verband met datum bezoek op zand $(P<0,1)$.

- Samengevat was er een licht positief effect van graslandleeftijd (model 2) een positief verband met stikstofbodemoverschot (model 1), een wisselend effect van meetmelk per ha (model $1,+$ veen, - klei en zand) en een positief verband met grasopbrengst $\mathrm{N}$ per ha, met name op zand (model 1 en 2).

\section{Graslandplanten}

\section{Aantal plantensoorten}

- Correlatie: Er waren geen significante correlaties tussen het aantal plantensoorten en de KPI's, bodemparameters en omgevingskenmerken van het bedrijf.

- Regressie: Model 1 resulteerde niet in een significant verband met de KPI's. In model $2\left(R^{2}{ }_{a d j}=0,19\right.$; $\mathrm{P}<0,1)$ was er een positief effect van leeftijd gras op zand.

- Samengevat: Er was een positief effect van graslandleeftijd op zand, maar er was geen verband met de overige KPI's.

\section{Aantal grassoorten}

- Correlatie: Het aantal soorten gras was negatief gecorreleerd met het aandeel eigen voer $(r=-0,59$; $\mathrm{P}<0,05)$ op klei en positief met de $\mathrm{NH}_{3}$-emissie $(r=0,61 ; \mathrm{P}<0,05)$ op klei.

- Regressie: Zowel model 1 als model 2 resulteerden niet in significante verbanden met de KPI's.

- Samengevat: Er was geen verband tussen het aantal grassoorten en de KPI's.

\section{Aantal kruidensoorten}

- Correlatie: Het aantal soorten kruiden was negatief gecorreleerd met grasopbrengst $(r=-0,40$; $\mathrm{P}<0,05)$ op alle bedrijven en positief met meetmelk per ha $(r=0,58 ; P<0,05)$ op veen.

- Regressie: In model $1\left(R^{2}\right.$ adj $\left.=0,46 ; P<0,001\right)$ was er een positief effect van graslandleeftijd $(P<0,05)$ met een significante negatieve interactie met \% OS: gemiddeld was er op zand en klei een positief effect van graslandleeftijd, op veen juist negatief. Bij stikstofbodemoverschot was er ook een significante interactie met \% OS: gemiddeld genomen resulteerde dit op klei en zand in een negatief effect van bodemoverschot en op veen juist positief. Voor meetmelk per ha was er een negatieve interactie met \% lutum: gemiddeld was er op veen en klei een negatief verband met meetmelk per ha en op zand een positief verband. In model $2\left(R^{2}\right.$ adj $\left.=0,41 ; P<0,001\right)$ was er een positief verband met graslandleeftijd op zand $(P<0,05)$, een positief verband met meetmelk per ha op veen $(P<0,001)$ en een negatief verband met grasopbrengst $N$ op veen $(P<0,05)$.

- Samengevat vertoonde het aantal soorten kruiden een positief verband met graslandleeftijd op zandgrond (model 1 en 2). Het verband met stikstofbodemoverschot was negatief op zand en klei en juist positief op veen (model 1). De verbanden voor meetmelk per ha waren tegenstrijdig in model 1 
en model 2. Graslandopbrengst N vertoonde een negatief verband met name op veen (model 2, correlatie).

\section{Insecten}

\section{Aantal insectensoorten gevangen met zuigmethode}

- Correlatie: Er zijn geen significante correlaties gevonden tussen het aantal insectensoorten gevangen met de zuigmethode en de KPI's, bodemparameters en omgevingskenmerken van het bedrijf.

- Regressie: In model $1\left(R^{2}\right.$ adj $\left.=0,46 ; P<0,05\right)$ was er een negatief hoofdeffect van grasleeftijd met een negatieve interactie met \% OS: gemiddeld genomen resulteerde dit in een negatief effect van graslandleeftijd op zand. Er was een tendens voor een negatieve interactie tussen stikstofbodemoverschot en \% lutum, resulterend in een negatief effect van stikstofbodemoverschot op klei en veen. Meetmelk per ha vertoonde de trend voor een positieve interactie met \% lutum resulterend in een positief verband op klei en veen. Grasopbrengst vertoonde een negatief verband $(P<0,001)$ in interactie met \% lutum en \% OS resulterend in een negatief effect op klei en zand. Er was een positief verband met de diversiteit van natte omgevingselementen en een negatief verband met de diversiteit van open elementen. Model 2 resulteerde niet in significante verbanden met de KPI's.

- Samengevat: Alleen model 1 resulteerde in significante verbanden tussen het aantal soorten insecten met de KPI's en er was een sterke interactie met grondsoort: Voor het aantal soorten (zuigmethode) was er een negatief verband met graslandleeftijd op zand en een negatief verband met stikstofbodemoverschot op klei en veen. Het verband met meetmelk was inconsistent. Er was een trend voor een negatief verband met grasopbrengst op klei en zand. Er was een positief verband met de diversiteit van natte omgevingselementen en een negatief verband met de diversiteit van open elementen.

\section{Aantal insecten gevangen met zuigmethode}

- Correlatie: Er zijn geen significante correlaties gevonden tussen het aantal insecten gevangen met de zuigmethode en de KPI's, bodemparameters en omgevingskenmerken van het bedrijf.

- Regressie: in model $1\left(\mathrm{R}^{2}{ }_{\text {adj }}=0,19 ; \mathrm{P}<0,05\right)$ was er een positieve interactie tussen graslandleeftijd en $\%$ lutum, resulterend in een positief effect van graslandleeftijd, met name op klei en veen. $\mathrm{Er}$ was tevens een positief effect van de diversiteit van boomrijke omgevingselementen. Model 2 resulteerde niet in een significant verband met de KPI's.

- Samengevat: Alleen model 1 resulteerde in significante verbanden tussen het aantal soorten insecten met de KPI's. Bij het aantal insecten gevangen met de zuigmethode was er een positief verband met graslandleeftijd, met name op veen. Er was tevens een positief effect van de diversiteit van boomrijke omgevingselementen.

\section{Aantal insecten gevangen met plakvallen}

- Correlatie: Er zijn geen significante correlaties gevonden tussen aantal insecten gevangen met plakvallen en de KPI's, bodemparameters en omgevingskenmerken van het bedrijf.

- Regressie: In model $1\left(R^{2}\right.$ adj $\left.=0,33 ; P<0,01\right)$ was er een negatieve interactie van stikstofbodemoverschot met \% lutum, wat gemiddeld genomen resulteerde in een negatief verband met stikstofbodemoverschot, met name op klei en veen. Meetmelk per ha vertoonde een negatieve interactie met \% OS, resulterend in een negatief verband met meetmelk, met name op veen. Er was een negatief verband met de diversiteit van open elementen in de omgeving. Model 2 resulteerde niet in een significant verband met de KPI's.

- Samengevat: Alleen model 1 resulteerde in significante verbanden tussen het aantal soorten insecten met de KPI's: een negatief verband met stikstofbodemoverschot, met name op klei en veen, een negatief verband met meetmelk, met name op veen. Er was een negatief verband met de diversiteit van open elementen in de omgeving.

\section{Aantal insecten 4-10 $\mathrm{mm}$ gevangen met plakvallen}

- Correlatie: Er was een positieve correlatie tussen aantal insecten van 4-10 mm gevangen met plakvallen en stikstofbodemoverschot op veen $(r=0,70 ; P<0,01)$. 
- Regressie: In model $1\left(R^{2}\right.$ adj $\left.=0,28 ; P<0,05\right)$ was er een negatief verband met grasleeftijd $(P<0,05)$, met name op zand (positieve interactie met \% lutum). Er was een negatieve interactie tussen stikstofbodemoverschot en \% lutum: gemiddeld genomen was er een negatief effect van stikstofbodemoverschot op klei en veen. Er was een significante interactie tussen meetmelk per ha en $\%$ OS resulterend in een positief effect van meetmelk per ha, met name op veen. Er was een negatief effect van de diversiteit van boomrijke en open omgevingselementen en een positief effect van natte elementen. In 2odel $2\left(R^{2}\right.$ adj $\left.=0,12 ; P<0,05\right)$ was er een positief effect van stikstofbodemoverschot op veen.

- Samengevat: Het aantal insecten van 4-10 mm op de plakvallen vertoonde een inconsistent verband met graslandleeftijd, stikstofbodemoverschot en meetmelk per ha. Er waren sterke interacties met grondsoort, maar deze kwamen vaak niet overeen tussen correlatie en de beide regressiemodellen. Er was een negatief effect van de diversiteit van boomrijke en open omgevingselementen en een tendens voor een positief effect van natte elementen.

\section{Vogels}

\section{Aantal soorten insecteneters}

- Correlatie: $\mathrm{Er}$ is een negatieve correlatie gevonden met grasland in \% van totale bedrijfsoppervlakte $(r=-0,39 ; P<0,05)$ voor alle bedrijven.

- Regressie: Model 3 leverde geen significante verbanden met de KPI's op. In model $4\left(R^{2}\right.$ adj $=0,13$; $P<0,05)$ was er een negatief verband tussen het aantal soorten insecteneters en grasland in $\%$ van totale bedrijfsoppervlakte $(P<0,05)$.

- Samengevat was er een negatief verband tussen het aantal soorten insecteneters en grasland in \% van totale bedrijfsoppervlakte (correlatie en model 4).

\section{Aantal soorten wormeneters}

- Correlatie: $\mathrm{Er}$ is een positieve correlatie gevonden met grasland in \% van totale bedrijfsoppervlakte $(r=0,60 ; P<0,05)$ op veen, een positieve correlatie met grasopbrengst $(r=0,64 ; P<0,05)$ op veen, een positieve correlatie met blijvend grasland in $\%$ van totale bedrijfsoppervlakte $(r=0,62 ; P<0,05)$ en stikstofbodemoverschot $(r=0,66 ; P<0,05)$ op zand.

- Regressie: In model $3\left(R^{2}\right.$ adj $\left.=0,26 ; P<0,01\right)$ was er een positief verband tussen het grasland in \% van totale bedrijfsoppervlakte op klei en veen, maar juist negatief op zand (negatieve interactie met $\%$ zand). Er was een tendens voor een negatief verband met meetmelk per ha. In model 4 $\left(R^{2}\right.$ adj $\left.=0,26 ; P<0,01\right)$ was er een positief effect van blijvend grasland in $\%$ van totale bedrijfsoppervlakte op zand en er was een positief effect van de grasopbrengst $\mathrm{N}$. De diversiteit van boomrijke elementen vertoonde een negatief verband.

- Samengevat was er een positief verband tussen het aantal soorten wormeneters en het grasland in $\%$ van totale bedrijfsoppervlakte met name op veen en klei en juist negatief op zand (model 3), een positief verband met bodem $\mathrm{N}$ overschot op zand (correlaties), een tendens voor een negatief verband met meetmelk per ha (model 3), en een positief verband met grasopbrengst (model 4 ) met name op veen (correlatie). De diversiteit van boomrijke elementen vertoonde een negatief verband (model 4).

\section{Aantal soorten roofvogels}

- Correlatie: Er zijn geen significantie correlaties gevonden tussen het aantal soorten roofvogels en de KPI's, bodemparameters en omgevingskenmerken van het bedrijf.

- Regressie: In model $3\left(R^{2}\right.$ adj $\left.=0,22 ; P<0,05\right)$ was er een negatieve interactie van blijvend grasland in $\%$ van totale bedrijfsoppervlakte met het \% veen (negatief effect van blijvend grasland in \% van totale bedrijfsoppervlakte, met name op veen), er was een negatieve interactie tussen het stikstofbodemoverschot en \% zand, een tendens voor een negatieve interactie tussen de meetmelk per ha en $\%$ veen en een tendens voor een negatief verband met de grasopbrengst $\mathrm{N}$. In model 4 $\left(R^{2}=0,37 ; R^{2}\right.$ adj $\left.=0,26 ; P<0,05\right)$ was er een positief effect van grasland in $\%$ van totale bedrijfsoppervlakte op veen, een negatief effect van blijvend grasland in \% van totale bedrijfsoppervlakte op veen en een negatief effect van stikstofbodemoverschot. Ook was er een negatief verband met grasopbrengst $\mathrm{N}$.

- Samengevat was er een positief verband tussen het aantal soorten roofvogels met grasland in \% van totale bedrijfsoppervlakte op veen (model 4) en een negatief verband met blijvend grasland in 
\% van totale bedrijfsoppervlakte op veen (model 3 en 4). Er was een overwegend negatief verband met stikstofbodemoverschot (model 3 en 4) en met grasopbrengst $N$ (model 3 en 4 ).

\section{Totaal aantal soorten vogels}

- Correlatie: Er is een positieve correlatie gevonden met meetmelk per ha $(r=0,63 ; P<0,05)$ op zand.

- Regressie: Er was geen significant verband tussen het aantal soorten vogels en de KPI's in model 3 en 4.

- Samengevat was er geen significant verband tussen het totaal aantal soorten vogels en de KPI's.

\section{Zoogdieren}

\section{Aantal hazen}

- Correlatie: $\mathrm{Er}$ is een positieve correlatie gevonden met $\mathrm{NH}_{3}$-emissie $(0,49 ; \mathrm{P}<0,01)$ voor alle bedrijven, met $\mathrm{NH}_{3}$-emissie op veen $(0,81 ; \mathrm{P}<0,01)$ en met $\%$ veen $(0,38 ; \mathrm{P}<0,05)$ voor alle bedrijven.

- Regressie: In model $3\left(R^{2} a d j=0,23 ; p<0,05\right)$ was er een negatieve interactie met $\%$, grasland (met name op veen), er was een negatieve interactie met stikstofbodemoverschot (met name op zand) en een positieve interactie met grasopbrengst $\mathrm{N}$ per ha (met name op veen). In model 4 $\left(R^{2}{ }_{a d j}=0,17 ; p<0,05\right)$ was er een positieve interactie met stikstofbodemoverschot (met name op veen).

- Samengevat: Er was een significant verband tussen aantal hazen en de KPI's grasland in \% van totale bedrijfsoppervlakte (hoe hoger grasland in \% van totale bedrijfsoppervlakte, hoe minder hazen) en grasopbrengst $\mathrm{N}$ per ha (hoe hoger, hoe meer hazen, met name op veen).

Stikstofbodemoverschot gaf geen eenduidig verband; positief op veen en negatief op zand.

\section{Aantal reeën}

- Correlatie: Er zijn negatieve correlaties gevonden met grasopbrengst op veen $(-0,81 ; P<0,01)$, stikstofbodemoverschot op alle bedrijven $(-0,44 ; \mathrm{P}<0,01)$, stikstofbodemoverschot op zand $(-0,84$; $P<0,01)$, aandeel eigen voerproductie op veen $(-0,75 ; P<0,01)$, aandeel eigen voerproductie op zand $(-0,79 ; \mathrm{P}<\ldots)$, aandeel blijvend grasland op alle bedrijven $(-0,43 ; \mathrm{P}<0,05)$, aandeel blijvend grasland op veen $(-0,80 ; \mathrm{P}<0,01)$, grasland in $\%$ van totale bedrijfsoppervlakte op veen $(-0,85$; $\mathrm{P}<0,01)$ en de $\mathrm{NH}_{3}$-emissie van alle bedrijven $(-0,45 ; \mathrm{P}<0,01)$. Er zijn positieve correlaties gevonden met de diversiteit aan boomrijke natuur op alle bedrijven $(0,47 ; \mathrm{P}<0,01)$, diversiteit aan boomrijke natuur op veen $(0,59 ; \mathrm{P}<0,05)$, diversiteit aan natte natuur op alle bedrijven $(0,36$; $\mathrm{P}<0,05)$, diversiteit aan natte natuur op zand $(0,75 ; \mathrm{P}<0,01)$ en diversiteit aan open natuur op alle bedrijven $(0,38 ; P<0,05)$. Tenslotte zijn er positieve correlaties gevonden met het $\%$ zand in alle bedrijven $(0,37 ; \mathrm{P}<0,05)$ en het $\%$ zand op veen $(0,58 ; \mathrm{P}<0,05)$.

- Regressie: er waren vele significante verbanden tussen het aantal reeën en de KPI's in model 3 $\left(R^{2}{ }_{a d j}=0,65 ; p<0,001\right)$ en model $4\left(R^{2}{ }_{a d j}=0,82 ; p<0,001\right)$ met vele interacties met grondsoort. Echter, de vergelijking van de beide modellen en de correlatie leverde een aantal tegenstrijdige verbanden op.

- Samengevat: Voor het aantal reeën was er een inconsistent verband met grasland in \% van totale bedrijfsoppervlakte en de meetmelk per ha. Op veen was er een negatief verband met blijvend grasland in \% van totale bedrijfsoppervlakte en grasopbrengst per ha. Er was een positief verband met de aanwezigheid van natte natuur, maar het verband met boomrijk en open natuur was inconsistent. 
Wageningen University \& Research Postbus 29703

2502 LS Den Haag

T 0703358330

E communications.ssg@wur.nl

www.wur.nl/economic-research

Wageningen Economic Research RAPPORT

2020-107
De missie van Wageningen University \& Research is 'To explore the potential of nature to improve the quality of life'. Binnen Wageningen University \& Research bundelen Wageningen University en gespecialiseerde onderzoeksinstituten van Stichting Wageningen Research hun krachten om bij te dragen aan de oplossing van belangrijke vragen in het domein van gezonde voeding en leefomgeving. Met ongeveer 30 vestigingen, 6.500 medewerkers (5.500 fte) en 12.500 studenten behoort Wageningen University \& Research wereldwijd tot de aansprekende kennisinstellingen binnen haar domein. De integrale benadering van de vraagstukken en de samenwerking tussen verschillende disciplines vormen het hart van de unieke Wageningen aanpak.

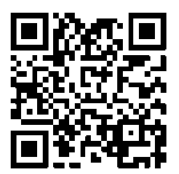





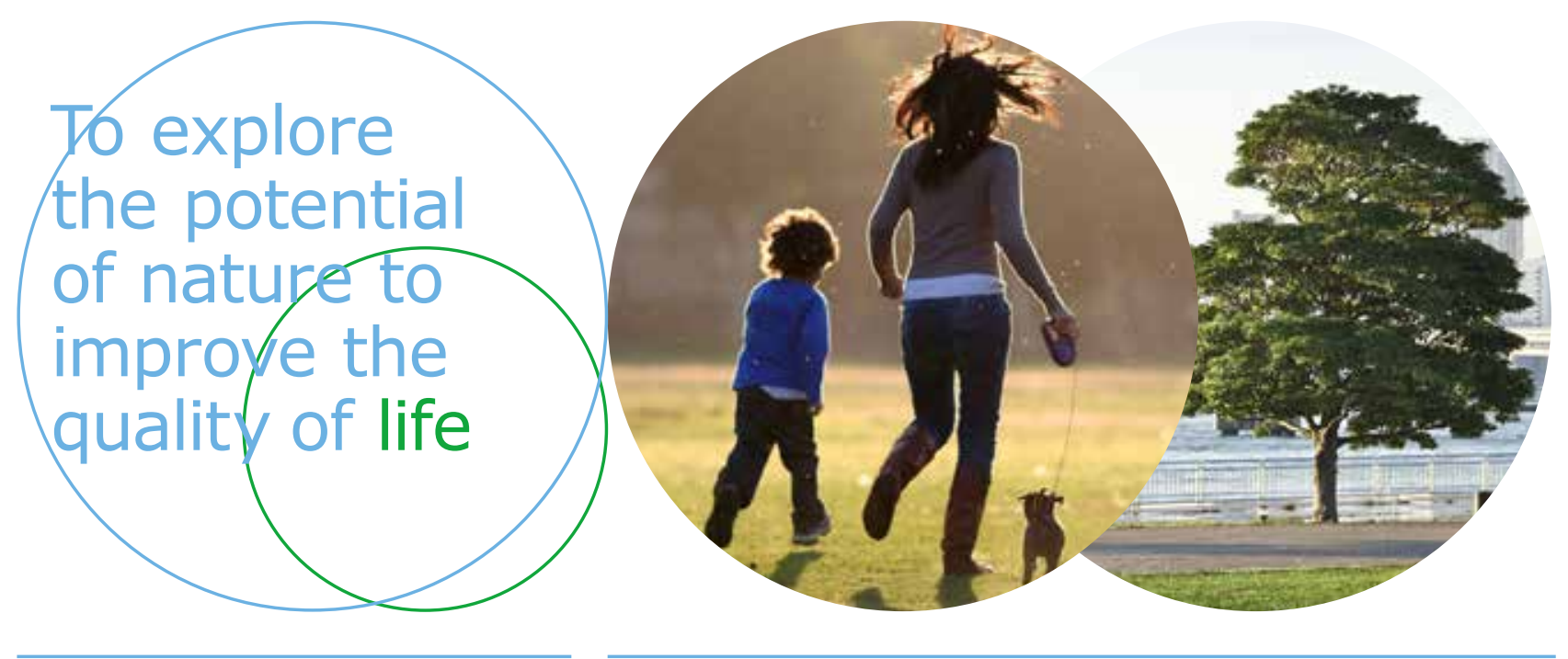

Wageningen University \& Research Postbus 29703

2502 LS Den Haag

T 0703358330

E communications.ssg@wur.nl www.wur.nl/economic-research

Rapport 2020-107

ISBN 978-94-6395-067-1

De missie van Wageningen University \& Research is 'To explore the potential of nature to improve the quality of life'. Binnen Wageningen University \& Research bundelen Wageningen University en gespecialiseerde onderzoeksinstituten van Stichting Wageningen Research hun krachten om bij te dragen aan de oplossing van belangrijke vragen in het domein van gezonde voeding en leefomgeving. Met ongeveer 30 vestigingen, 6.500 medewerkers ( $5.500 \mathrm{fte}$ ) en 12.500 studenten behoort Wageningen University \& Research wereldwijd tot de aansprekende kennisinstellingen binnen haar domein. De integrale benadering van de vraagstukken en de samenwerking tussen verschillende disciplines vormen het hart van de unieke Wageningen aanpak. 